Aus dem Institut für Vegetative Physiologie und Pathophysiologie

(Prof. Dr. med. G. Burckhardt)

im Zentrum Physiologie und Pathophysiologie

der Medizinischen Fakultät der Georg-August-Universität Göttingen

\title{
Einfluss des Transkriptionsfaktors B-cell lymphoma 6 (BCL6) auf die Expression renaler Transportproteine
}

\section{INAUGURAL - DISSERTATION}

zur Erlangung des Doktorgrades

für Zahnheilkunde

der Medizinischen Fakultät der

Georg-August-Universität zu Göttingen

vorgelegt von

Aline Noel Millé

aus

Otterndorf

Göttingen 2016 
Dekan:

I. Berichterstatter:

II. Berichterstatter:

III. Berichterstatter:
Prof. Dr. rer. nat. H. K. Kroemer

Prof. Dr. med. Gerhard Burckhardt

PD Dr. rer. nat. Mladen Tzvetkov

Prof. Dr. med. dent. Rainer Mausberg

Tag der mündlichen Prüfung: 07.11.2016 


\section{Inhaltsverzeichnis}

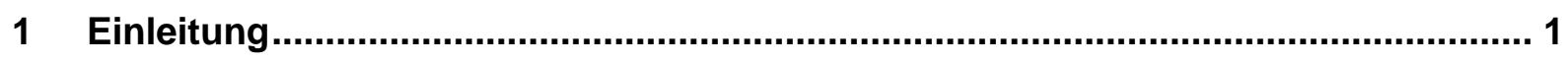

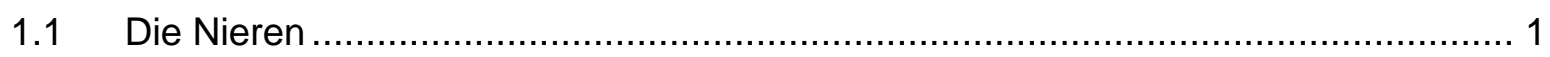

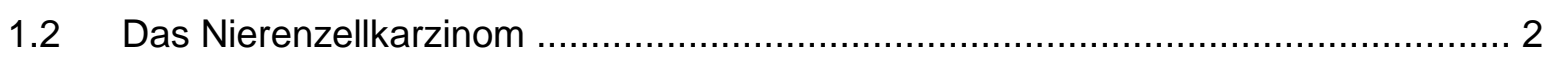

1.2.1 Chemoresistenz des Nierenzellkarzinoms ............................................... 2

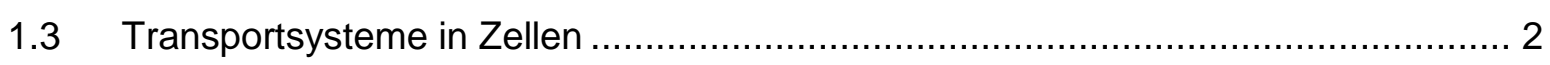

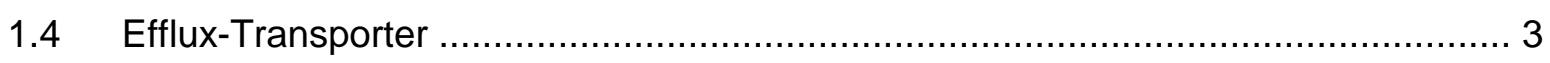

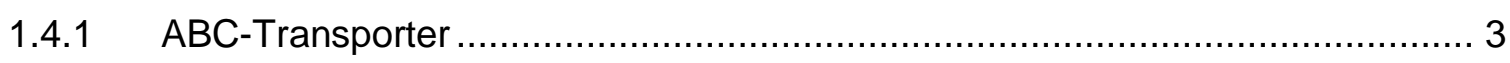

1.4.1.1 Das Multidrug-Resistance-Protein 1 (MDR1) …...................................... 4

1.4.1.2 Das Multidrug-Resistance-associated-Protein 2 (MRP2) ............................ 4

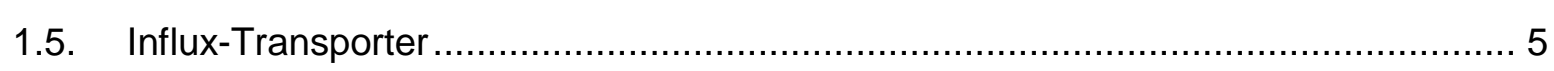

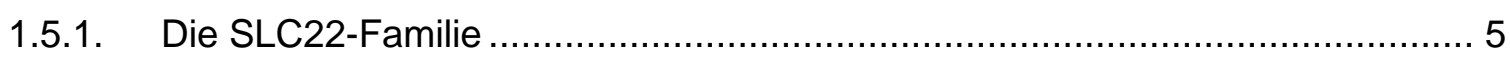

1.5.1. Die humanen Organische-Anionen-Transporter ......................................... 5

1.5.1.1. Der humane Organische-Anionen-Transporter 1 (OAT1) ............................ 6

1.5.1.2. Der humane Organische-Anionen-Transporter 3 (OAT3) ............................. 6

1.5.1.3. Der humane Organische-Anionen-Transporter 4 (OAT4) ............................. 7

1.5.1.4. Der humane Organische-Anionen-Transporter 10 (OAT10) ......................... 7

1.5.2. Die humanen Organische-Kationen-Transporter ....................................... 8

1.5.2.1. Der humane Organische-Kationen-Transporter 1 (OCT1) ............................ 8

1.5.2.2. Der humane Organische-Kationen-Transporter 2 (OCT2).......................... 8

1.5.2.3. Der humane Organische-Kationen-Transporter 3 (OCT3).......................... 9

1.6. Transkriptionsfaktoren ......................................................................... 9

1.6.1. Transkriptionsfaktor B-cell lymphoma 6 (BCL6) ....................................... 9

1.7. Aufgabenstellung und Zielsetzung ...........................................................

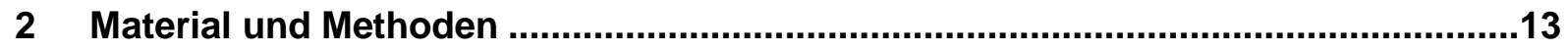

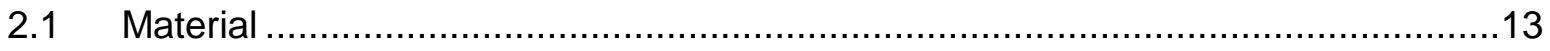

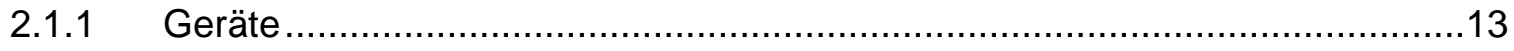

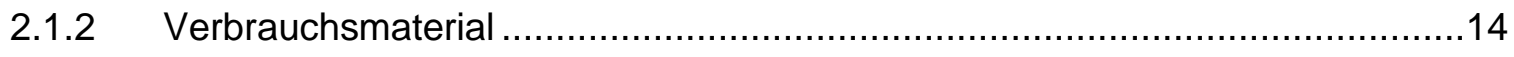

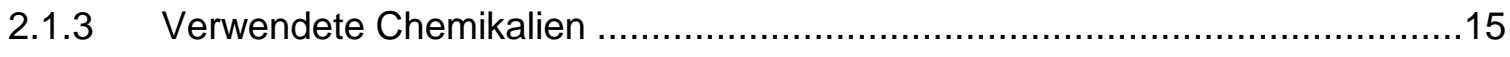

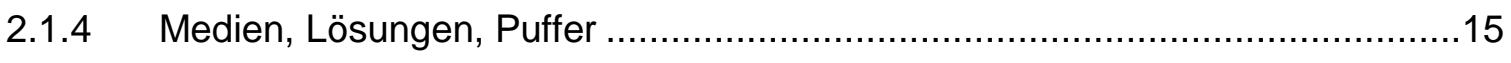

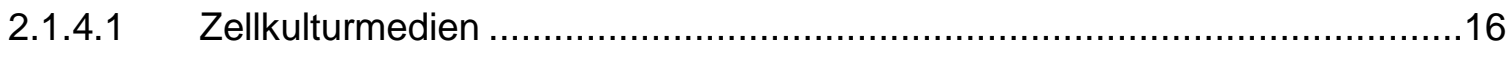

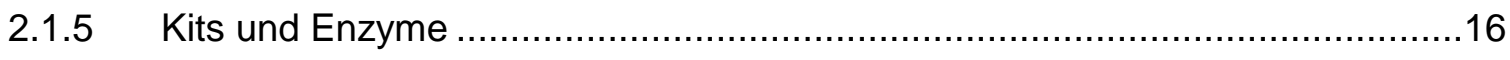

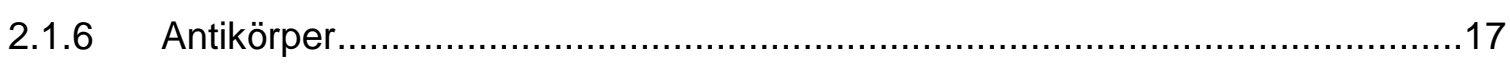

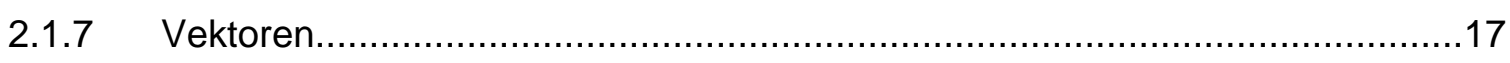

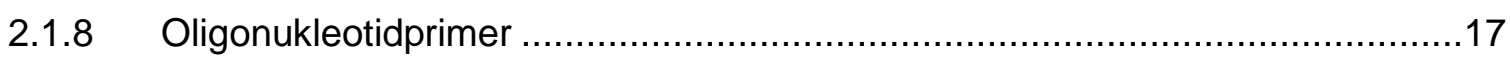

2.1.9 TaqMan $\AA$ Genexpressions-Assays ................................................... 


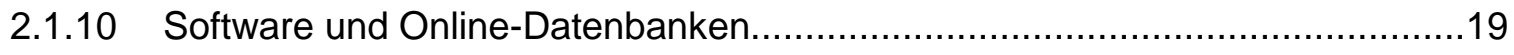

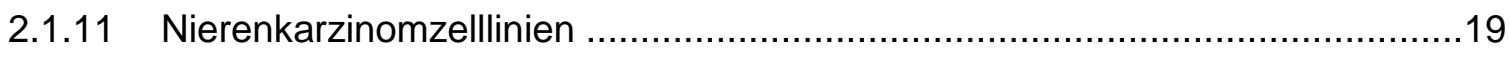

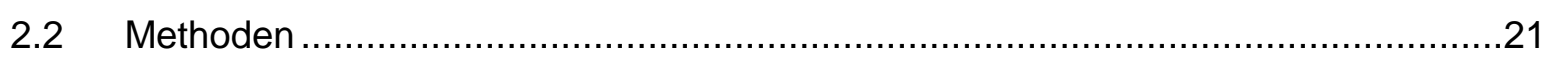

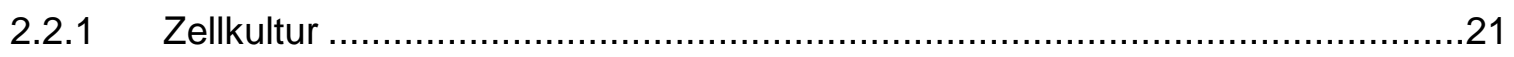

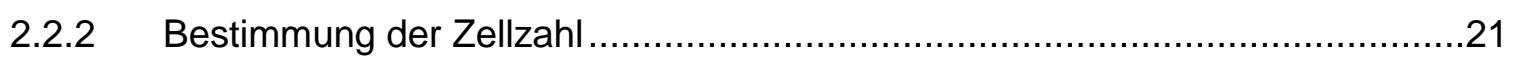

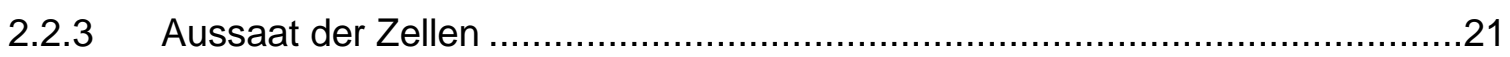

2.2.4 Transfektionstechnik unter Verwendung der Lipofektamin-Methode................22

2.2.5 BCL6-Expressionsanalyse in Nierenkarzinomzelllinien ................................22

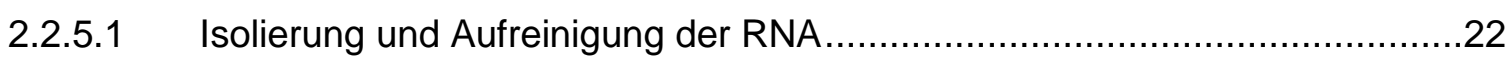

2.2.5.2 Reverse Transkription (cDNA-Synthese) .............................................23

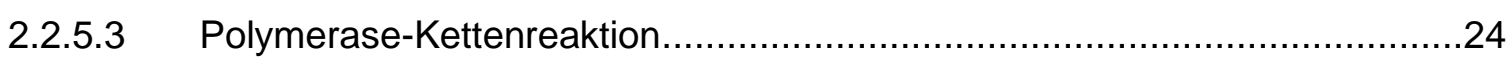

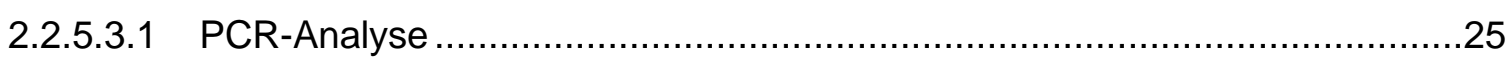

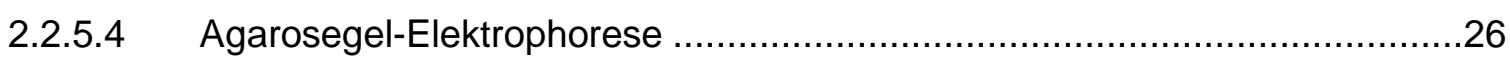

2.2.5.5 Quantitative TaqMan $\AA$ real-time PCR ..................................................26

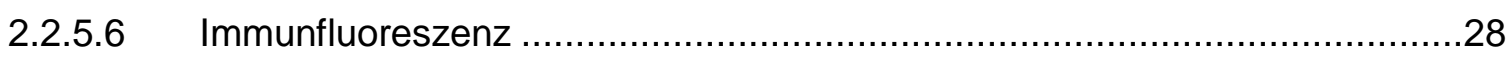

2.2.6 Untersuchung der Caspase-3-Aktivität ....................................................29

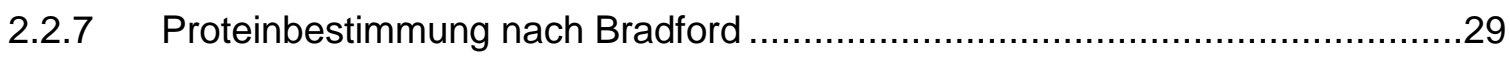

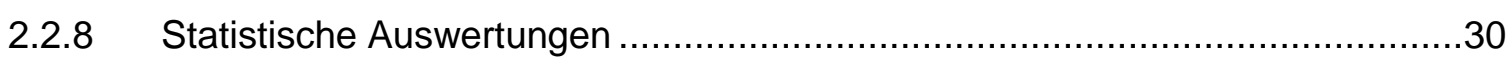

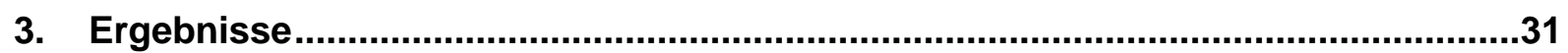

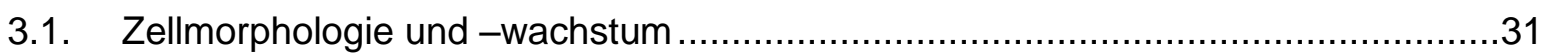

3.2. Nachweis des BCL6-Gens in Nierenkarzinomzelllinien ......................................32

3.2.1. Nachweis des BCL6-Gens in der Zelllinie 786-O ...........................................

3.2.2. Nachweis des BCL6-Gens in der Zelllinie ACHN........................................33

3.2.3. Nachweis des BCL6-Gens in der Zelllinie LN78 ............................................33

3.2.4. Nachweis des BCL6-Gens in der Zelllinie RCCNG1 ...................................34

3.3. Expression von SLC-Transportern und ABC-Transportern in

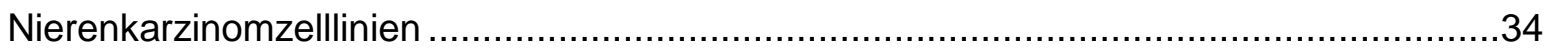

3.3.1. GAPDH-Expression unter Einfluss der BCL6-Überexpression .......................35

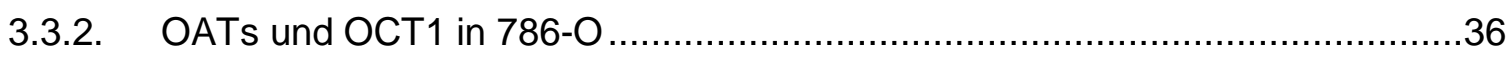

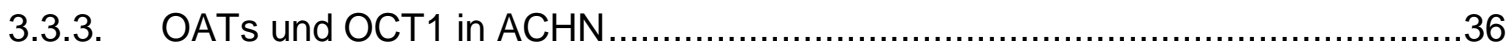

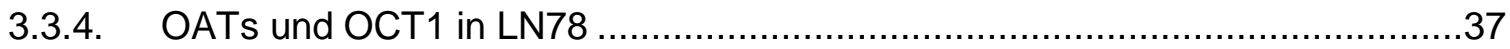

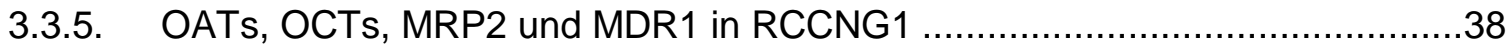

3.3.6. Zusammenfassung der real-time PCR-Analyse ...........................................39

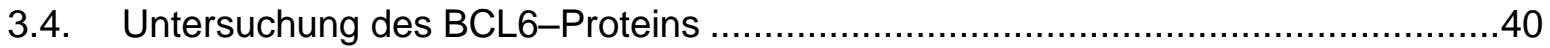

3.5. Der Effekt von BCL6 auf die Chemosensitivität der Nierenkarzinomzelllinie RCCNG1 
3.5.1. Der Einfluss von BCL6 auf die Chemosensitivität von RCCNG1-Zellen gegenüber 5-Fluorouracil

3.5.2. Der Einfluss von BCL6 auf die Chemosensitivität von RCCNG1-Zellen gegenüber Irinotecan

3.5.3. Der Einfluss von BCL6 auf die Chemosensitivität von RCCNG1-Zellen gegenüber Oxaliplatin . .45

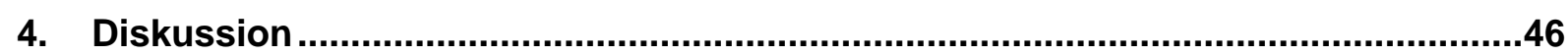

4.1. Nachweis des BCL6-Gens in den Nierenkarzinomzelllinien. .46

4.2. Beeinflussung der Expression renaler Transportproteine in 786-O, ACHN, LN78 und RCCNG1 durch BCL6

4.2.1. Beeinflussung der Expression der Influx-Transporter in 7860-O, ACHN, LN78 und RCCNG1 durch BCL6

4.2.2. Beeinflussung der Expression der Efflux-Transporter MDR1 und MRP2 in RCCNG1 durch BCL6

4.3. Nachweis des BCL6-Proteins in den Nierenkarzinomzelllinien .52

4.4. Einfluss des BCL6-Proteins auf die Chemosensitivität von RCCNG1-Zellen .52

4.5. Einfluss weiterer Faktoren auf die Nierenkarzinomtherapie.... .56

5. Zusammenfassung. .58

6. Anhang. 59

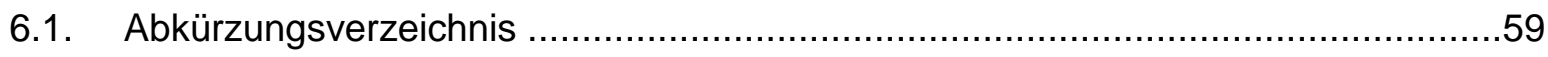

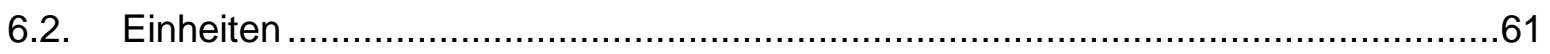

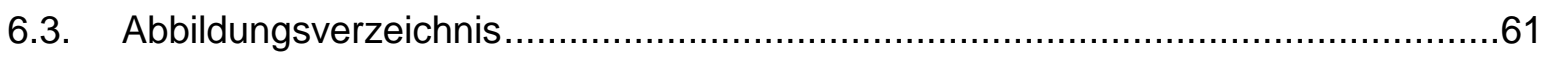

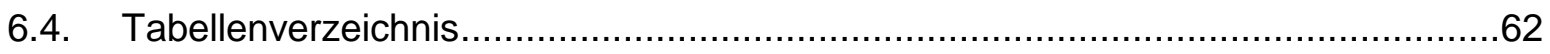

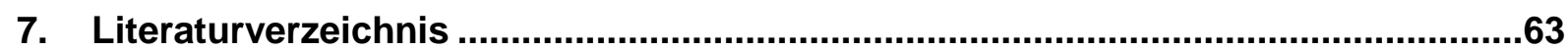




\section{Einleitung}

\subsection{Die Nieren}

Die Nieren sind das wichtigste Ausscheidungsorgan des Körpers (Schmidt et al. 2010). Zu den Hauptaufgaben der Nieren zählen neben der Elimination harnpflichtiger Substanzen die Regulierung des Wasser- und Elektrolythaushaltes sowie die Regulation des Säure-BasenHaushaltes (Klinke et al. 2010, Schmidt et al. 2010). Des Weiteren sind die Nieren an der langfristigen Blutdruckregulation, der Mineralisierung der Knochen sowie als endokrines Organ an der Bildung der Hormone Erythropoietin, Calcitriol und Renin beteiligt (Klinke et al. 2010). Nephrone bilden die funktionellen Grundeinheiten der Nieren. Jede Niere besitzt mehr als eine Million Nephrone (Klinke et al. 2010). Zu den fünf Hauptsegmenten eines Nephrons zählen der Glomerulus, der proximale Tubulus, die Henle-Schleife, der distale Tubulus und das Sammelrohr (Abbildung 1.1).

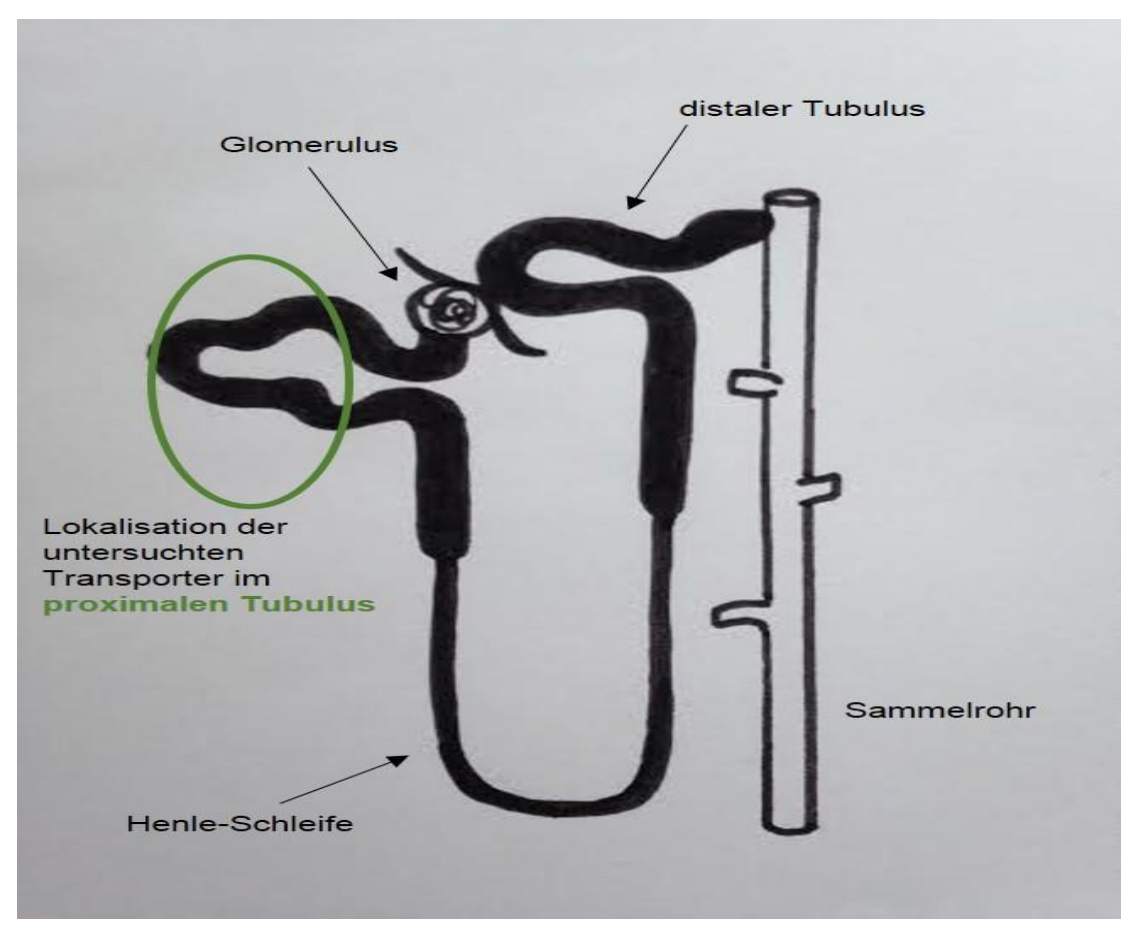

Abbildung 1.1: Das Nephron.

Die schematische Darstellung des Nephrons zeigt die fünf Hauptsegmente des Nephrons: den Glomerulus, den proximalen Tubulus, die Henle-Schleife, den distalen Tubulus und das Sammelrohr. Zusätzlich markiert die grüne Ellipse die Lokalisation der in dieser Arbeit untersuchten Transportproteine (eigene Darstellung). 


\subsection{Das Nierenzellkarzinom}

Das Nierenzellkarzinom (NZK) ist ein Adenokarzinom und stellt derzeit etwa 3,8\% aller bösartigen Tumorerkrankungen (Koul et al. 2011) und $86 \%$ aller malignen Nierenerkrankungen dar (Hautmann und Huland 2001). Damit gehört das NZK zu den zehn häufigsten bösartigen Tumoren der Welt (Ljungberg et al. 2011). Das Klarzellkarzinom, welches von den proximalen Tubuluszellen ausgeht, stellt mit etwa $70 \%$ den häufigsten Typ des NZK dar (Goyal et al. 2013). Von dem überwiegend im fünften bis siebten Lebensjahrzehnt auftretenden Karzinom des proximalen Tubulus sind Männer doppelt so häufig betroffen wie Frauen (Hautmann und Huland 2001, Sültmann et al. 2005). Etwa ein Drittel der Patienten mit einem NZK weisen bei der Diagnosestellung bereits Metastasen auf. Die 5-Jahresüberlebensrate beträgt bei diesen Patienten nach Motzer et al. weniger als $5 \%$ (Motzer et al. 1996). In der Literatur werden je nach Ausdehnung der Tumorerkrankung verschiedene Therapiemöglichkeiten des NZK beschrieben.

Die radikale Tumornephrektomie, welche erstmals 1952 von Foley beschrieben wurde, stellt beim lokalisierten NZK die Behandlung der Wahl dar (Foley et al. 1952, Dempke 2006). Bei der radikalen Tumornephrektomie wird die erkrankte Niere zusammen mit dem umgebenden Gewebe (Nebenniere und Fettkapsel) entfernt. Das NZK gilt als chemo-, hormon- und strahlenresistenter Tumor (Dempke 2006, Hautmann und Huland 2001, Pal et al. 2015).

\subsubsection{Chemoresistenz des Nierenzellkarzinoms}

Zahlreiche Studien sowohl zu Mono- als auch Kombinationstherapien mit Chemotherapeutika als Behandlungskonzept zeigen, dass das NZK nur gering chemotherapiesensibel ist (George et al. 2002, Waters et al. 2004, Stadler et al. 2006). Komplette Remissionen des Tumors sind selten (Dutcher 2002). Eine maximale Remissionsrate von $16 \%$ wird durch das Zytostatikum Vinblastin beschrieben (Dempke 2006). Die Ursache für die Chemoresistenz ist noch nicht vollständig geklärt (Walsh et al. 2009). Eine mögliche Erklärung für die verminderte Empfindlichkeit der Nierenkarzinomzellen gegenüber einem Zytostatikum ist der Heraustransport (Efflux) von Zytostatika aus den Tumorzellen (Sharom 2008, Gupta et al. 2011a). Die ATP-binding cassette-Transporter (ABC-Transporter) wurden in der Literatur im Hinblick auf die Chemosensibilität von Tumoren beschrieben (Nomura et al. 2005, Huang 2007, Walsh et al. 2009).

\subsection{Transportsysteme in Zellen}

Transportproteine spielen eine wichtige Rolle bezüglich der Funktion und Proliferation von Zellen sowie des Zelltodes, weil sie für den Influx und Efflux von Nährstoffen, Metaboliten und Pharmazeutika verantwortlich sind (Huang 2007). 
Ohne Transporter könnten die meisten Stoffe die Lipiddoppelschicht der Zellmembran nicht passieren (Alberts et al. 2011). Membrantransportern werden im Organismus vielfältige Aufgaben und Funktionen der Resorption und Ausscheidung zugeschrieben. Sie sind dafür zuständig, dass lonen oder hydrophile Substanzen die Lipiddoppelschicht der Zellmembran passieren können und stellen damit eine Verbindung zwischen Extra- und Intrazellularraum dar (Alberts et al. 2011).

Als Transportarten werden der passive Transport in Richtung des elektrochemischen Gradienten und der aktive Transport entgegen dem elektrochemischen Gradienten unterschieden (Alberts et al. 2011). Der aktive Transport kann nur durch die Kopplung mit einem zweiten energieliefernden Prozess erfolgen (Alberts et al. 2011). Primär aktiver Transport liegt vor, wenn ein Substrat unter Energieverbrauch transportiert wird. Die Energie dafür stammt von „primären“ Energiequellen wie z.B. die Hydrolyse von ATP zu ADP und Phosphat (Silbernagl und Despopoulos 2012). Zu den primär aktiven Transportern zählen die in dieser Arbeit untersuchten ABC-Transporter (Bergeron et al. 2008). Beim sekundär aktiven Transport wird die Energie indirekt verbraucht. Die potentielle Triebkraft eines bestehenden Konzentrationsgradienten, der zuvor durch ATP-Hydrolyse aufgebaut wurde, wird dazu genutzt, um eine Substanz entgegen ihrem Konzentrationsgradienten zu transportieren (Alberts et al. 2011). Zu diesem gekoppelten Transport zählen Symporter und Antiporter (Alberts et al. 2011). SLC-Transporter transportieren ihre Substrate passiv oder sekundär aktiv (Bergeron et al. 2008). Beim tertiär aktiven Transport liefert ein sekundär aktiver Transport den Antrieb (Schmidt et al. 2010).

Die Transportproteine lassen sich in Kanäle und Carrier einteilen (Alberts et al. 2011). Kanäle sind porenbildende Transmembranproteine und ermöglichen den passiven Transport (Bergeron et al. 2008, Alberts et al. 2011). Carrier haben Bindungsstellen für spezielle Substrate, ändern nach der Substratbindung ihre Konformation und transportieren das Substrat dadurch auf die andere Seite der Membran (Alberts et al. 2011). ABC- und SLCTransporter werden zu den Carriern gezählt.

\subsection{Efflux-Transporter}

\subsubsection{ABC-Transporter}

Die Superfamilie der ABC-Transporter (ABC = ATP-binding cassette) stellt eine der größten Membranproteinfamilien dar (Hoffmann und Kroemer 2004), die von einer großen Genfamilie kodiert wird (Huang 2007) und erstmalig in Bakterien entdeckt wurde. ABC-Transporter sind durch membrandurchspannende Domänen und ATP-Bindungsdomänen gekennzeichnet (Hoffmann und Kroemer 2004). Durch die Hydrolyse von gebundenem ATP zu ADP 
gewinnen die Transportproteine Energie für den aktiven Transport strukturell unterschiedlicher Substrate über eine Zellmembran (Dean und Allikmets 1995, Hoffmann und Kroemer 2004, Nomura et al. 2005). Diese ATP-getriebenen Transportsysteme exportieren Zytostatika und andere Substrate aus der Zelle und verhindern somit deren intrazelluläre Akkumulation. Da Efflux-Transporter als Gegenspieler der Influx-Transporter der SLC-Familie betrachtet werden, ist die Expression der Efflux-Transporter insbesondere im Rahmen der Chemotherapie zu berücksichtigen. Im Hinblick auf die Überwindung der Chemoresistenz von Karzinomzellen wurden in den letzten Jahren viele Untersuchungen an ABC-Transportern unternommen (Nomura et al. 2005, Shnitsar et al. 2009). Von den neun Mitgliedern der MRP-Proteine (ABCC) sind MRP4 und das in dieser Arbeit untersuchte MRP2 die wichtigsten Efflux-Transporter der Nieren (Masereeuw und Russel 2012).

\subsubsection{Das Multidrug-Resistance-Protein 1 (MDR1)}

Das Multidrug-Resistance-Protein 1 (MDR1; P-Glykoprotein, P=Permeabel) wurde erstmalig 1976 in einer Cholchicin-resistenten Zelllinie als Effluxtransporter detektiert (Huls et al. 2009). Zhou beschreibt MDR1 als einen der klinisch wichtigsten Membrantransporter (Zhou 2008). Der Transporter wird vorwiegend in der Leber, dem Intestinum, der Blut-HirnSchranke und den Nieren exprimiert (Huang 2007, Huls et al. 2009). In den Nieren ist MDR1 in der apikalen Membran proximaler Tubuli lokalisiert und für den Efflux von Substraten in den Primärharn verantwortlich (Masereeuw und Russel 2012). MDR1 interagiert insbesondere mit hydrophoben Medikamenten mit einer polyaromatischen Hauptkette und neutraler oder positiver Ladung (Huang 2007). Dazu gehören die Zytostatika Etoposid, Vinblastin und Adriamycin (Huang 2007). Neben den Zytostatika werden u.a. Antikonvulsiva, Calciumkanalantagonisten, Proteaseinhibitoren und antivirale Substanzen zu den Substraten von MDR1 gezählt (Masereeuw und Russel 2012).

\subsubsection{Das Multidrug-Resistance-associated-Protein 2 (MRP2)}

Das membranständige Glykoprotein wird vorzugsweise in der apikalen Plasmamembran von Hepatozyten, in proximalen Tubuluszellen der Nieren und im Intestinum exprimiert (Schaub et al. 1999, Chen und Tiwari 2011). Schaub et al. haben beobachtet, dass MRP2 in $95 \%$ der Klarzellkarzinome der Nieren exprimiert wird (Schaub et al. 1999). Die Substratspezifität des Transportproteins beinhaltet ein breites Spektrum endogener und exogener organischer Anionen (Gerk und Vore 2002, Masereeuw und Russel 2012). Diese werden meist in der Zelle an Glucuronid oder Glutathion konjugiert und anschließend von MRP2 aus der Zelle transportiert (Hoffmann und Kroemer 2004). Methotrexat ist als Substrat von MRP2 beschrieben (Chen und Tiwari 2011, Masereeuw und Russel 2012). In-vitro- Studien konnten 
zeigen, dass auch die Zytostatika Irinotecan, Cisplatin, Paclitaxel und Vincristin mit MRP2 interagieren (Chen und Tiwari 2011). Cui et al. zeigten, dass die Überexpression von MRP2 in transfizierten HEK-293 Zellen (Zellen humaner embryonaler Niere) die Resistenz gegenüber Cisplatin erhöht (Cui et al. 1999).

\subsection{Influx-Transporter}

\subsubsection{Die SLC22-Familie}

Die solute carrier 22 (SLC22)-Genfamilie enthält fünf Typen von Transportproteinen, die Organische-Anionen-Transporter (OATs), die Organische-Kationen-Transporter (OCTs), Organische-Kationen/Carnitin-Transporter (OCTNs), die unbekannten Substrat-Transporter (USTs) und Urat-Transporter (URATs) (Jonker und Schinkel 2004, Wu et al. 2009).

In der vorliegenden Arbeit wurden von den Mitgliedern der SLC22-Familie die humanen Transporter OAT1, OAT3, OAT4, OAT10, OCT1, OCT2 und OCT3 untersucht. Es handelt sich dabei um Transmembranproteine, welche im Körper des Menschen vorwiegend in den Nieren und der Leber exprimiert werden (Jacobsson et al. 2007). Sie sind für die Aufnahme, die Verteilung und die Ausscheidung von Toxinen, endogenen Substanzen sowie Medikamenten inklusive Zytostatika verantwortlich (Jacobsson et al. 2007). Die Transporter enthalten 12 Transmembrandomänen mit intrazellulären N- und C-Termini und einem großen extrazellulären Loop zwischen der ersten und zweiten Transmembrandomäne (Burckhardt und Wolff 2000). Im Gegensatz zu den ABC-Transportern, die in den letzten drei Jahrzehnten eingehend untersucht wurden, sind die Transporter der SLC22-Familie hinsichtlich der Chemoresistenz von Tumorzellen wenig erforscht und beschrieben (Gupta et al. 2011a).

\subsubsection{Die humanen Organische-Anionen-Transporter}

OATs werden in der Leber, den Nieren, der Plazenta, in der Blut-Hirn-Schranke und im Nasenepithel exprimiert (Burckhardt 2012). In den Nieren sind OATs in der Plasmamembran proximaler Tubuluszellen lokalisiert (Burckhardt und Burckhardt 2011, Burckhardt 2012). OATs sind polyspezifische Transporter (Burckhardt 2012), die sowohl mit negativ geladenen endogenen Metaboliten als auch einer Vielzahl von Pharmaka wie z.B. Antibiotika, antiviralen Wirkstoffen und Diuretika interagieren (Übersichten in: Burckhardt 2012, Emami Riedmaier et al. 2012). 


\subsubsection{Der humane Organische-Anionen-Transporter 1 (OAT1)}

In den Nieren ist OAT1 (SLC22A6) in der basolateralen Membran des proximalen Tubulus lokalisiert und unter anderem für die Aufnahme von Arzneimitteln vom Blut in die Zelle verantwortlich (Burckhardt und Burckhardt 2011). Die Expression von OAT1 ist zwar in einer Vielzahl weiterer Gewebe wie zum Beispiel im Gehirn (Alebouyeh et al. 2003) und in der Plazenta (Koepsell und Endou 2004), beschrieben, doch in keinem anderen Organ ist die Expression von OAT1 so hoch wie in den Nieren (Hosoyamada et al. 1999, Sekine et al. 1997, Nishimura und Naito 2005). OAT1 ist ein Antiporter, der intrazelluläres a-Ketoglutarat gegen extrazelluläre organische Anionen und Xenobiotika austauscht (Burckhardt 2012). Die para-Aminohippursäure (PAH; Diagnostikum zur Untersuchung der Nierenfunktion) dient als Modell-Substrat zur Charakterisierung der OAT1-Funktion (Hosoyamada et al. 1999, Burckhardt 2012). OAT1 ist für seine umfassende Substratspezifität bekannt (Wright und Dantzler 2004) und interagiert mit mehr als hundert Substraten (Sekine et al. 2006). Dazu zählen endogene Substrate wie Dicarboxylate, Monocarboxylate, Urat und Hormone wie Prostaglandin $E_{2}$ und $F_{2 \alpha}$ (Sekine et al. 2006, Burckhardt und Burckhardt 2011, Burckhardt 2012). Außerdem wurde eine Interaktion von OAT1 mit ACE-Hemmern wie Captopril, Angiotensin-II-Rezeptor Blockern wie Olmesartan, Diuretica, Statinen, Urikosurika, Antibiotika wie Penicillin und Tetracyclin, antiviralen Medikamenten wie Acyclovir, nichtsteroidalen antiinflammatorischen Pharmaka wie z.B. Acetylsalicylsäure und HistaminH2-Rezeptor-Antagonisten wie Cimetidin nachgewiesen (Burckhardt 2012). Zudem ist bekannt, dass das Zytostatikum Methotrexat, ein Analogon der Folsäure (Vitamin B9), mit OAT1 interagiert (Rizwan und Burckhardt 2007, Burckhardt und Burckhardt 2011, Burckhard 2012).

\subsubsection{Der humane Organische-Anionen-Transporter 3 (OAT3)}

Das Gen für OAT3 (SLC22A8) ist auf dem Chromosom 11q12.3 neben dem Gen für OAT1 (SLC22A6) lokalisiert (Burckhardt 2012, Emami Riedmaier et al. 2012). Immunhistochemisch ist OAT3 in den Nieren genau wie OAT1 in der basolateralen Membran des proximalen Tubulus lokalisiert (Cha et al. 2001, Burckhardt 2012). Eine erhöhte Aktivität das OAT3Promotors wurde in Anwesenheit von cAMP beschrieben (Ogasawara et al. 2006). Wegner et al. zeigten, dass der Transkriptionsfaktor BCL6 den Oat3-Promotor von Ratten aktiviert (Wegner et al. 2012). Motohashi et al. haben postuliert, dass OAT3 der in den humanen Nieren am stärksten exprimierte OAT sein könnte, da sie eine höhere Expression von OAT3mRNA als von anderen OATs in den Nieren detektieren konnten (Motohashi et al. 2002). Andere Studien widerlegen diese Aussage, da z.B. Sakurai et al. (2004) und Hilgendorf et al. (2007) gleich viel oder mehr OAT1-mRNA nachweisen konnten. Ähnlich wie OAT1 fungiert OAT3 als Antiporter für $\alpha$-Ketoglutarat gegen organische Anionen und ist auch durch eine 
facettenreiche Substratspezifität gekennzeichnet (Emami Riedmaier et al. 2012). Einige Substratspezifitäten von OAT3 ähneln denen des OAT1 (Wright und Dantzler 2004), allerdings transportiert OAT3 lipophilere Substrate als OAT1 (Burckhardt und Burckhardt 2011, Emami Riedmaier et al. 2012). OAT3 transportiert eine Reihe endogener Substanzen wie z.B. cAMP, Cortisol, Prostaglandin $\mathrm{E}_{2}$ und Urat (Emami Riedmaier et al. 2012). OAT3 interagiert auch mit einigen pharmakologischen Substanzen wie z.B. Diuretika, ACEInhibitoren, antiviralen Substanzen, Histamin-H2-Rezeptor-Antagonisten, nichtsteroidalen antiinflammatorischen Medikamenten und Antibiotika wie Cephalosporine (Rizwan und Burckhardt 2007, Burckhardt und Burckhardt 2011, Burckhard 2012, Emami Riedmaier et al. 2012). Cha et al. zeigten den OAT3-vermittelten Transport des Zytostatikums Methrotrexat (Cha et al. 2001). Für das Zytostatikum Methotrexat weist OAT3 eine höhere Affinität als OAT1 auf (Burckhardt 2012). Bislang konnte nur am Oat3 von Mäusen ein Transport des in dieser Arbeit untersuchten Zytostatikums 5-Fluorouracil nachgewiesen werden (Kobayashi et al. 2004).

\subsubsection{Der humane Organische-Anionen-Transporter 4 (OAT4)}

Im Jahr 2000 berichteten Cha et al. erstmalig von der Isolierung des humanen OrganischeAnionen-Transporters 4 (OAT4, SLC22A11) aus der Niere (Cha et al. 2000). OAT4 ist in der apikalen Membran, an der lumenwärts gerichteten Seite proximaler Tubuluszellen lokalisiert (Cha et al. 2000, Ekaratanawong et al. 2004) und in der Plazenta nachgewiesen (Cha et al. 2000). Hagos et al. konnten nachweisen, dass OAT4 sowohl als Efflux- als auch als InfluxTransporter arbeiten kann und bezeichneten OAT4 als asymmetrischen Antiporter, der $\alpha-$ Ketoglutarat gegen organische Anionen und Arzneistoffe in Influx- und Efflux-Richtung austauscht (Hagos et al. 2007). Die Resorption von organischen Anionen erfolgt demnach im Austausch gegen intrazelluläre Dicarboxylat- oder Hydroxylionen, die Sekretion von organischen Anionen erfolgt im Austausch gegen Chlorid aus dem Extrazellularraum (Burckhardt und Burckhardt 2011, Emami Riedmaier et al. 2012). OAT4 vermittelt den Influx von Östrogensulfat und Urat, DHEAS, Prostaglandin $E_{2}$ und Prostaglandin $F_{2 a}$ sowie von Medikamenten wie z.B. Diuretika und Methotrexat (Hagos et al. 2007, Burckhardt und Burckhardt 2011, Burckhardt 2012). Ein bekanntes Efflux-Substrat ist PAH (Burckhardt 2012).

\subsubsection{Der humane Organische-Anionen-Transporter 10 (OAT10)}

OAT10 (SLC22A13) wird in der apikalen Membran der proximalen Tubuluszellen exprimiert (Bahn et al. 2008). Dieser Transporter hat eine besonders hohe Substratspezifität für das Vitamin Nicotinat (Bahn et al. 2008, Burckhardt und Burckhardt 2011). OAT10 vermittelt als 
Antiporter den Austausch von Urat oder Nicotinat aus dem Extrazellularraum gegen intrazelluläres Laktat, Succinat oder Glutathion (Burckhardt 2012). Bahn et al. zeigten, dass OAT10 den Austausch organischer Anionen und nicht, wie seit seiner Isolierung als organic cation transporter like 3 angenommen, organischer Kationen vermittelt (Bahn et al. 2008).

\subsubsection{Die humanen Organische-Kationen-Transporter}

Die Organische-Kationen-Transporter (OCTs) werden ebenfalls der Familie der SLC22Transportproteine zugeordnet und sind überwiegend in den Nieren und in der Leber exprimiert (Burckhardt und Wolff 2000). OCT-Transportern wird in erster Linie die Vermittlung der hepatischen (OCT1) und der renalen Exkretion (OCT2 und OCT3) zugeschrieben. OCTs weisen eine Affinität für positiv geladene endogene Substanzen wie Adrenalin und Noradrenalin und für positiv geladene exogene Substanzen wie Methylphenylpyridinum (MPP+) und Tetraethylammoniumion (TEA) auf (Burckhardt und Wolff 2000). Der Transport durch OCT-Proteine erfolgt aktiv entlang eines Konzentrationsgradienten (Gupta et al. 2011a).

\subsubsection{Der humane Organische-Kationen-Transporter 1 (OCT1)}

OCT1 (SLC22A1) wurde 1997 aus der humanen Leber isoliert (Zhang et al. 1997). OCT1 ist hauptsächlich in der Leber exprimiert (Heise et al. 2012). In verschiedenen Studien konnte die Expression von OCT1 in Zellen von Kolonkarzinomen und Polypen nachgewiesen werden (Gupta et al. 2011a). OCT1 ist für die Aufnahme verschiedener sowohl endogener als auch exogener Substanzen verantwortlich und vermittelt den Transport der Zytostatika Irinotecan, Imatinib, Oxaliplatin, Picoplatin, Paclitaxel und Mitoxantron, welche sehr verschiedene Strukturen aufweisen (Zhang et al. 2006, Gupta et al. 2011a, Gupta et al. 2011b).

\subsubsection{Der humane Organische-Kationen-Transporter 2 (OCT2)}

OCT2 (SLC22A2) wurde 1997 in der humanen Niere identifiziert (Gorboulev et al. 1997). OCT2 wird in der basolateralen Membran des proximalen Tubulus exprimiert (Koepsell et al. 2003) und vermittelt dort die Eliminierung positiv geladener endogener und exogener Substanzen aus dem Blutplasma (Gupta et al. 2011a). Kitada et al. konnten in ihren Untersuchungen die Expression von OCT2 in Zellen des kolorektalen Karzinoms nachweisen (Kitada et al. 2008). OCT2 besitzt eine ähnliche Substratspezifität wie OCT1 (Übersicht in: Koepsell et al. 2007). OCT2 vermittelt u.a. den Transport des Antidiabetikums Metformin vom Blut in die proximalen Tubuluszellen (Chen et al. 2009). Cisplatin ist das bekannteste 
Zytostatikum, welches vom OCT2 transportiert wird (Ciarimboli et al. 2005). Zudem vermittelt OCT2 den Transport von Oxaliplatin (Yonezawa et al. 2006, Zhang et al. 2006) und Ifosfamid (Ciarimboli et al. 2011).

\subsubsection{Der humane Organische-Kationen-Transporter 3 (ОСТ3)}

OCT3 (SLC22A3) wird in vielen humanen Geweben exprimiert (Koepsell et al. 2003). OCT3 wurde unter anderem in den Nieren (Wu et al. 2000) und in der Plazenta (Sata et al. 2005) nachgewiesen. Shnitsar et al. konnten die Expression von OCT3 in Nierenkarzinomzelllinien detektieren (Shnitsar et al. 2009). OCT3 hat eine ähnliche Substratspezifität wie OCT1 und OCT2 (Übersicht in: Koepsell et al. 2007). OCT3 transportiert die Zytostatika Irinotecan, Oxaliplatin, Melphalan und Vincristin (Shnitsar et al. 2009, Gupta et al. 2011a).

\subsection{Transkriptionsfaktoren}

Die Initiation der Transkription stellt die wichtigste Stufe der Regulation der Genexpression dar (Löffler und Petrides 2014). Die Transkription von Genen wird durch Transkriptionsfaktoren reguliert (Campbell und Reece 2006, Fulton et al. 2009). Dabei handelt es sich um kleine Proteine, welche an spezifische Regionen der DNA binden und die Promotoren aktivieren oder reprimieren können (Liu et al. 1999). Auf diese Weise ermöglichen Transkriptionsfaktoren eine selektive Regulation und Expression von Genen. Innerhalb eines Promotors können viele verschiedene Transkriptionsfaktoren binden, da dieser mehrere Bindungsstellen umfasst.

\subsubsection{Transkriptionsfaktor B-cell lymphoma 6 (BCL6)}

Der Transkriptionsfaktor B-cell lymphoma 6 (BCL6) wurde in B-Zellen identifiziert und charakterisiert (Wagner et al. 2011). BCL6 wird beim Menschen im Keimzentrum der Lymphfollikel erhöht exprimiert (Dent et al. 2002, Basso und Dalla-Favera 2012). In ausgereiften Kardiomyozyten wurde die BCL6-Expression ebenfalls beschrieben (Altieri et al. 2012). In Mäusen konnte die BCL6-Expression unter anderem in der Leber (Zhang et al. 2012) und in Spermatozyten (Kojima et al. 2001) gezeigt werden. BCL6 spielt eine wichtige Rolle für die Embryonalentwicklung, die Immunantwort, die Lymphozytendifferenzierung und ist für die Zellzykluskontrolle unerlässlich (Staudt et al. 1999, Dent et al. 2002, Wagner et al. 2011, Basso und Dalla-Favera 2012). Eine der Hauptfunktionen von BCL6 ist die Repression der Transkription (Dent et al. 2002, Wagner et al. 2011, Basso und Dalla-Favera 2012). Als Repressor bindet BCL6 meistens direkt an dessen Konsensussequenz (Basso und DallaFavera 2012). Es ist ebenso möglich, dass BCL6 die Genexpression indirekt durch Protein- 
Protein-Interaktionen mit weiteren Transkriptionsfaktoren reguliert (Dent et al. 2002). Durch die Änderung der BCL6-Expression werden transkriptionale Veränderungen zahlreicher Gene induziert, was eine Regulation von Signalwegen wie z.B. des Wnt-Signalwegs in der Zelle induzieren kann (Basso und Dalla-Favera 2012).

Das auf Chromosom 3q27 lokalisierte BCL6-Gen ist $24 \mathrm{~kb}$ lang und kodiert für ein Protein mit der molekularen Größe von 95 kDa (Ye et al. 1993, Chang et al. 1996, Dent et al. 2002). BCL6 gehört zur Familie der BTB/POZ/Zink-Finger (Bric à Brac/Tramtrack/Broad complex/POX Virus Zink-Finger) Transkriptionsfaktoren (Chang et al. 1996, Bereshchenko et al. 2002, Lemercier et al. 2002, Miles et al. 2005, Basso und Dalla-Favera 2012). Die BTB/POZ-Domäne befindet sich am Amino-Terminus (N-Terminus) und ist für die ProteinProtein-Interaktion sowie die Homo- und Heterodimerisierung des BCL6-Proteins essentiell (Miles et al. 2005, Costoya 2007, Basso und Dalla-Favera 2012). Der Mittelteil des BCL6Proteins enthält drei PEST-Domänen (reich an Prolin, Glutaminsäure, Serin und Theronin) und ist an der Stabilität und Aktivität des Proteins beteiligt (Basso und Dalla-Favera 2012). Innerhalb dieses Mittelteils kann p300, ein Co-Aktivator, an das Protein binden und es durch Acetylierung inaktivieren (Bereshchenko et al. 2002). Am Carboxy-Terminus (C-Terminus) des BCL6-Proteins befindet sich die Zink-Finger-Domäne, welche aus sechs Zink-Fingern des Krüppel-Typs besteht und für die Protein-Protein-Interaktion von BCL6 und die sequenzspezifische DNA-Bindung verantwortlich ist (Miles et al. 2005, Basso und DallaFavera 2012).

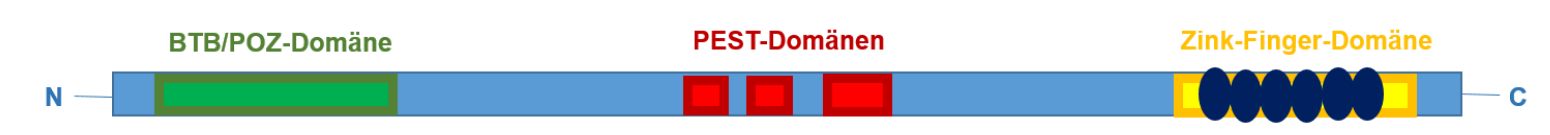

Abbildung 1.2: Schematische Darstellung des BCL6-Proteins.

Dargestellt sind die drei funktionell bedeutendsten Protein-Domänen. Die N-terminale BTB/POZ-Domäne (Bric à Brac/Tramtrack/Broad complex/POX Virus Zink-Finger), welche für die Protein-Protein-Interaktion und Dimerisierung des Proteins verantwortlich ist, die PEST-Domänen, welche für die Aktivität und Stabilität das Proteins zuständig sind und die C-terminale Zink-Finger-Domäne. Die Zink-Finger-Domäne besteht aus sechs Zink-Fingern des Krüppel-Typs und ist für die DNA-Bindung und ebenfalls für die Protein-Protein-Interaktion verantwortlich (eigene Darstellung in Anlehnung an Basso und Dalla-Favera 2012, S. 173).

Wegner et al. haben erstmalig gezeigt, dass BCL6 geschlechtsabhängig in den Nieren von Ratten exprimiert wird (Wegner et al. 2012). Dabei wurde BCL6 in männlichen Ratten höher als in weiblichen exprimiert (Wegner et al. 2012). Bisher ist wenig darüber bekannt, welche Rolle BCL6 in Nierenkarzinomzellen ausüben könnte, da bisherige Untersuchungen hauptsächlich in B- und T-Zellen durchgeführt worden sind (Wagner et al. 2011, Basso und Dalla-Favera 2012). Erste Resultate über den Einfluss von BCL6 auf die Transportproteine in den Nierenzellen wurden von Wegner et al. (2012) und Wegner et al. (2014) veröffentlicht. 
Dabei wurde BCL6 als möglicher geschlechtsabhängiger Regulator des Oat1 in Rattennieren identifiziert (Wegner et al. 2012). Des Weiteren wurde nachgewiesen, dass BCL6 die Genexpression des humanen OAT1 indirekt erhöhen kann (Wegner et al. 2014). Diese Erkenntnis steht im Kontrast zu den bisherigen Publikationen, in denen BCL6 als RepressorProtein der Transkription beschrieben wird (Chang et al. 1996, Lemercier et al. 2002, Wagner et al. 2011, Basso und Dalla-Favera 2012).

\subsection{Aufgabenstellung und Zielsetzung}

Nierenkarzinomzellen sprechen auf die systemische Chemotherapie nur wenig an (Longo et al. 2007). Ein Teil der Chemoresistenz beruht auf dem Efflux von Zytostatikamolekülen aus den Karzinomzellen (Sharom 2008). Bis heute ist die Expression der Influx-Transportproteine in Karzinomzellen unzureichend bekannt. Die Expression von Influx-Transportern der SLC22-Familie in Nierenkarzinomzellen könnte die Ansammlung spezieller Zytostatika in den Karzinomzellen erhöhen und damit entscheidend zu einer erhöhten Chemosensitivität der Karzinomzellen beitragen (siehe Abbildung 1.3). Die Erforschung dieser Transporter ist für das Verständnis und die Therapie von Nierenzellkarzinomen von hoher Relevanz. Neben der Evaluierung der Expression von Influx-Transportern ist auch die Kenntnis über mögliche Beeinflussungsmöglichkeiten der Expression und das Verständnis über die TransporterZytostatika-Interaktionen zur zielgerichteten Chemotherapie von großer Bedeutung.

Die im Rahmen dieser Arbeit untersuchten ABC- und SLC-Transporter haben einen großen Einfluss auf die Pharmakokinetik von Medikamenten (Huang 2007). In den Experimenten wird untersucht, ob Efflux-Transporter wie die ABC-Transporter und Influx-Transporter wie die SLC-Transporter in Nierenkarzinomzellinien exprimiert werden und ob sie einen Einfluss auf die Zystostatika-Resistenz dieser Zellen haben könnten.

Als Hauptziel dieser Arbeit gilt es zu untersuchen, ob der Transkriptionsfaktor BCL6 eine Rolle in der Expression von Transportproteinen in Nierenkarzinomzelllinien spielt und ob daraus resultierend die Chemosensitivität der Nierenkarzinomzellen erhöht werden kann. 

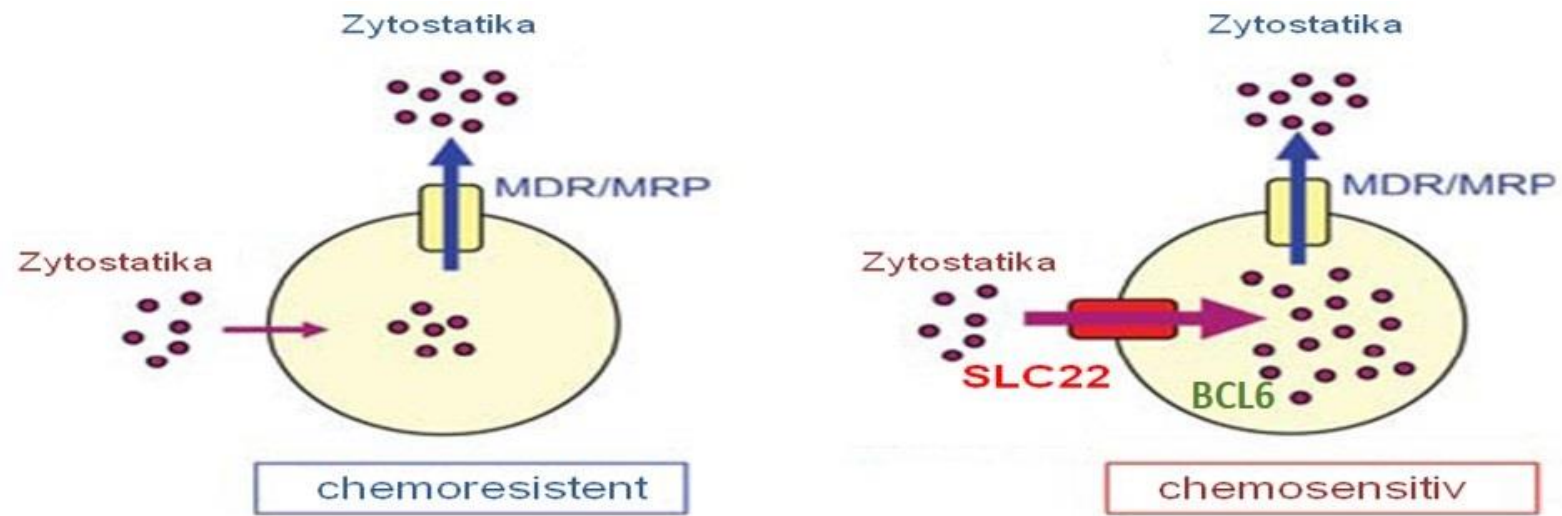

Abbildung. 1.3: Die Chemoresistenz der Nierenkarzinomzellen könnte durch gesteigerte Expression der SLC22-Transporter überwunden werden (modifiziert nach Gupta et al. 2011a).

Die Expression der SLC22-Transporter soll durch BCL6-Überexpression erhöht werden, damit diese Transporter Zytostatika vermehrt in die Karzinomzellen transportieren und eine erhöhte intrazelluläre Konzentration der Zytostatika bewirken. 


\section{Material und Methoden}

\subsection{Material}

Im folgenden Abschnitt werden die für die Durchführung der Experimente verwendeten Materialien und Geräte aufgeführt. Die verschiedenen Lösungen werden in ihren einzelnen Zusammensetzungen und Konzentrationen beschrieben.

\subsubsection{Geräte}

Die folgende Tabelle gibt einen Überblick über die in dieser Arbeit eingesetzten Geräte.

Tabelle 2.1: Geräte

\begin{tabular}{|c|c|c|}
\hline Gerät & Modell & Herkunft \\
\hline Brutschrank & $\begin{array}{l}\text { Function Line } \\
\text { (Heraeus Jubile Edition) }\end{array}$ & $\begin{array}{l}\text { Heraeus } \\
\text { (Hanau, Deutschland) }\end{array}$ \\
\hline Elektrophorese & Powersupply PPS 200-1D & $\begin{array}{l}\text { MWG-Biotech } \\
\text { (Ebersberg, Deutschland) }\end{array}$ \\
\hline Eismaschine & AF 10 & $\begin{array}{l}\text { Scotsman Ice Systems } \\
\text { (Herborn, Deutschland) }\end{array}$ \\
\hline Feinwaage & 2002 MP1 & $\begin{array}{l}\text { Sartorius } \\
\text { (Göttingen, Deutschland) }\end{array}$ \\
\hline Gefrierschrank $-80^{\circ} \mathrm{C}$ & Herafreeze & $\begin{array}{l}\text { Heraeus } \\
\text { (Hanau, Deutschland) }\end{array}$ \\
\hline Gefrierschrank $-20^{\circ} \mathrm{C}$ & Premium no frost & $\begin{array}{l}\text { Liebherr } \\
\text { (Ochsenhausen, } \\
\text { Deutschland) }\end{array}$ \\
\hline Gelkammer & Midi & $\begin{array}{l}\text { Eurofins MWG Operon } \\
\text { (Ebersberg, Deutschland) }\end{array}$ \\
\hline Geldokumentation & Gel Print 2000 I & $\begin{array}{l}\text { Biophotonics } \\
\text { (Ann Arbor, MI, USA) }\end{array}$ \\
\hline Mikroplattenleser & Mithras LB 940 & $\begin{array}{l}\text { Berthold Technologies } \\
\text { (Bad Wildbad, Deutschland) }\end{array}$ \\
\hline \multirow[t]{2}{*}{ Mikroskop } & Telaval 31 & $\begin{array}{l}\text { Carl Zeiss AG } \\
\text { (Oberkochen, Deutschland) }\end{array}$ \\
\hline & $\begin{array}{l}\text { Fluoreszenz-Mikroskop } \\
\text { AXIO Observer D1 }\end{array}$ & $\begin{array}{l}\text { Carl Zeiss AG } \\
\text { (Oberkochen, Deutschland) }\end{array}$ \\
\hline Mikroskopkamera & Powershot G2 & $\begin{array}{l}\text { Canon Inc } \\
\text { (Tokio, Japan) }\end{array}$ \\
\hline Mikrowelle & Privileg 8521 & $\begin{array}{l}\text { Quelle Schickedanz } \\
\text { (Fürth, Deutschland) }\end{array}$ \\
\hline Minizentrifuge & C-1200 & $\begin{array}{l}\text { Labnet International } \\
\text { (Woodbridge, NJ, USA) }\end{array}$ \\
\hline \multirow[t]{2}{*}{ PCR Cycler } & C1000 TM Thermal Cycler & $\begin{array}{l}\text { Bio-Rad Laboratories, Inc } \\
\text { (Hercules, CA, USA) }\end{array}$ \\
\hline & $\begin{array}{l}\text { PTC-200 Peltier Thermal } \\
\text { Cycler }\end{array}$ & $\begin{array}{l}\text { MJ Research } \\
\text { (Waterfront, MA, USA) }\end{array}$ \\
\hline real-time PCR Cycler & M×3005p & $\begin{array}{l}\text { Stratagene } \\
\text { (Waldbronn, Deutschland) }\end{array}$ \\
\hline
\end{tabular}




\begin{tabular}{lll}
\hline $\begin{array}{l}\text { RNA/DNA Calculator } \\
\text { und Photometer } \\
\text { Schüttler }\end{array}$ & Gene Quant II & $\begin{array}{l}\text { Pharmacia biotech } \\
\text { (Cambridge, England) }\end{array}$ \\
$\begin{array}{ll}\text { IKA Labortechnik } \\
\text { (Staufen, Deutschland) }\end{array}$ \\
$\begin{array}{l}\text { IKA } 250 \text { basic } \\
\text { (Staufen, Deutschland) }\end{array}$ & $\begin{array}{l}\text { W. Krannich GmbH \& Co KG } \\
\text { (Göttingen, Deutschland) }\end{array}$ \\
$\begin{array}{l}\text { Werkbank } \\
\begin{array}{l}\text { Zählkammer } \\
\text { (nach Neubauer) }\end{array}\end{array}$ & GFL & $\begin{array}{l}\text { Thermo Scientific } \\
\text { Paul Marienfeld GmbH \& Co }\end{array}$ \\
Zentrifugen & Save 2000 & $\begin{array}{l}\text { KG (Lauda-Königshofen, } \\
\text { Deutschland) }\end{array}$ \\
& Neubauer bright-line & $\begin{array}{l}\text { Heraeus } \\
\text { (Hanau, Deutschland) }\end{array}$ \\
& Megafuge 40 R & $\begin{array}{l}\text { Eppendorf AG } \\
\text { (Hamburg, Deutschland) }\end{array}$ \\
\hline
\end{tabular}

\subsubsection{Verbrauchsmaterial}

Die verwendeten Pipettenspitzen und Glasmaterialien wurden vor der Nutzung für 20 Minuten bei $120^{\circ} \mathrm{C}$ autoklaviert. Für die Zellkultur wurden hauptsächlich Einwegartikel verwendet.

Tabelle 2.2: Verbrauchsmaterial

\begin{tabular}{ll}
\hline Material & Hersteller \\
\hline Deckgläschen & $\begin{array}{l}\text { Menzel } \\
\text { (Braunschweig, Deutschland) }\end{array}$ \\
Reaktionsgefäße $(0,5 \mathrm{ml}, 1,5 \mathrm{ml}, 2 \mathrm{ml})$ & $\begin{array}{l}\text { Eppendorf } \\
\text { (Hamburg, Deutschland) }\end{array}$ \\
Meditrade \\
(Kiefersfelden, Deutschland)
\end{tabular}




\subsubsection{Verwendete Chemikalien}

Tabelle 2.3: Verwendete Chemikalien

\begin{tabular}{|c|c|}
\hline Stoffbezeichnung & Hersteller \\
\hline$\beta$-Mercaptoethanol & AppliChem (Darmstadt, Deutschland) \\
\hline Dimethylsulfoxid (DMSO) & AppliChem (Darmstadt, Deutschland) \\
\hline $\begin{array}{l}\text { Dulbecco's Modified Eagle's Medium with } \\
\text { high glucose (DMEM-HG) }\end{array}$ & Biochrom AG (Berlin, Deutschland) \\
\hline Ethidiumbromid & Sigma-Aldrich® (Steinheim, Deutschland) \\
\hline Ethylendiamintetraacetat (EDTA) & AppliChem (Darmstadt, Deutschland) \\
\hline Formaldehyd & Carl Roth® (Karlsruhe, Deutschland) \\
\hline Immersol $^{\mathrm{TM}} 518 \mathrm{~F}$ & Carl Zeiss AG (Oberkochen, Deutschland) \\
\hline Penicillin/Streptomycin (PEN-STREP) & $\begin{array}{l}\text { PAA Laboratories GmbH (Cölbe, } \\
\text { Deutschland) }\end{array}$ \\
\hline Phosphat-gepufferte Salzlösung (PBS) & AppliChem (Darmstadt, Deutschland) \\
\hline Poly-D-Lysin-Hydrobromid & Sigma-Aldrich® (Steinheim, Deutschland) \\
\hline $\mathrm{NaCl}$ & Merck (Darmstadt, Deutschland) \\
\hline Trypsin & Biochrom AG (Berlin, Deutschland) \\
\hline
\end{tabular}

\subsubsection{Medien, Lösungen, Puffer}

Alle Lösungen, Medien und Puffer wurden mit destilliertem $\mathrm{H}_{2} \mathrm{O}$ angesetzt und, wenn nicht anders beschrieben, bei Raumtemperatur gelagert. Die folgende Tabelle (Tab. 2.4) fasst die verwendeten Substanzen zusammen.

Tabelle 2.4: Lösungen und Puffer

\begin{tabular}{|c|c|}
\hline Lösung, Puffer & $\begin{array}{l}\text { Zusammensetzung /Hersteller, Produkt- } \\
\text { Nr. }\end{array}$ \\
\hline Agarosegel-Elektrophorese Ladepuffer $5 x$ & $\begin{array}{l}6,3 \mathrm{~g} \text { Glycerol } \\
2 \mathrm{ml} \mathrm{0,5} \mathrm{M} \mathrm{Ethylendiamintetraacetat} \\
\text { (EDTA) pH 8,0 } \\
50 \mu \mathrm{l} \mathrm{Trishydroxymethylaminomethan} \\
\text { (Tris) } \mathrm{HCl} \mathrm{pH} \mathrm{7,6} \\
0,001 \%(\mathrm{w} / \mathrm{v}) \text { Bromphenolblau } \\
0,001 \%(\text { w/v) Xylencyanol FF } \\
\text { mit nukleasefreiem aqua dest. auf } \\
10 \mathrm{ml} \text { aufgefüllt }\end{array}$ \\
\hline DNA Stopp (10 ml) & $\begin{array}{l}5 \mathrm{ml} \text { Glycerol } \\
2 \mathrm{ml} 0.5 \mathrm{M} \text { EDTA, } \mathrm{pH} 8.0 \\
50 \mu \mathrm{l} 2 \mathrm{M} \text { Tris- } \mathrm{HCl}, \mathrm{pH} 7.6 \\
\rightarrow \mathrm{zu} 10 \mathrm{ml} \text { sterilem und filtriertem } \mathrm{H}_{2} \mathrm{O} \\
\text { geben } \\
\rightarrow \text { wenige Kristalle Bromphenolblau zufügen } \\
\rightarrow \text { wenige Kristalle Xylencyanol FF zufügen }\end{array}$ \\
\hline Ethidiumbromid (Stammlösung) & $\begin{array}{l}\text { Sigma-Aldrich®, E1510 } \\
10 \mathrm{mg} / \mathrm{ml} \text { in nukleasefreiem aqua dest. }\end{array}$ \\
\hline PCR-Puffer (10x) & $\begin{array}{l}500 \text { mM KCl } \\
100 \text { mM Tris, pH } 9.0\end{array}$ \\
\hline
\end{tabular}




\begin{tabular}{ll}
\hline & $15 \mathrm{mM} \mathrm{MgCl}$ \\
& $1 \%$ Triton X-100 \\
PBS (Phosphat-gepufferte Salzlösung) & Applichem, A0964 \\
& $9,55 \mathrm{~g}$ in 1 I aqua dest. \\
Tris-Borat-EDTA (TBE)-Puffer 5x & $54 \mathrm{~g} / \mathrm{l} \mathrm{Tris-Base}$ \\
& $27,5 \mathrm{~g} / \mathrm{l}$ Borsäure \\
& $20 \mathrm{ml} 0,5 \mathrm{M}$ EDTA pH 8,5 \\
& aufgefüllt auf 1 I mit aqua dest. \\
Trypsin-Lösung & $0,1 \%$ Trypsin in PBS \\
\hline
\end{tabular}

\subsubsection{Zellkulturmedien}

Die Zellkulturmedien wurden vor der Nutzung auf $37^{\circ} \mathrm{C}$ vorgewärmt. Dem für die Zellkultur verwendeten zellspezifischen Kulturmedium Quantum 263 (mit L-Glutamin) wurden $100 \mathrm{U} / \mathrm{ml}$ Penicillin und $100 \mathrm{~g} / \mathrm{ml}$ Streptomycin zugefügt. Für die transiente Transfektion wurden die Zellen im Quantum 263 Medium ohne antibiotische Zusätze 24 Stunden kultiviert.

Tabelle 2.5: Zellkulturmedien

Dulbecco's Modified Eagle Medium with high Biochrom AG (Berlin, Deutschland) glucose (DMEM-HG)

Quantum 263 (Tumorzellmedium mit L- PAA Laboratories GmbH (Cölbe, Glutamin) Deutschland)

\subsubsection{Kits und Enzyme}

Tabelle 2.6: Kits und Enzyme

\begin{tabular}{|c|c|}
\hline Kit/Enzym & Hersteller \\
\hline EnzChek $\AA$ Caspase-3 Assay Kit \# 2 & Molecular probes ${ }^{\circledR}($ Eugene, OR, USA) \\
\hline Lipofectamine $^{T M} 2000$ & $\begin{array}{l}\text { Invitrogen }{ }^{\mathrm{TM}} \text {, Life Technologies (Carlsbad, } \\
\text { CA, USA) }\end{array}$ \\
\hline RNeasy ${ }^{\circledR}$ Mini Kit (50) & Qiagen (Hilden, Deutschland) \\
\hline Taq-Polymerase & in eigener Arbeitsgruppe hergestellt \\
\hline SuperscriptßII Reverse Transkriptase & $\begin{array}{l}\text { Invitrogen }{ }^{\mathrm{TM}} \text {, Life Technologies (Carlsbad, } \\
\text { CA, USA) }\end{array}$ \\
\hline
\end{tabular}




\subsubsection{Antikörper}

Tabelle 2.7: Antikörper

\begin{tabular}{ll}
\hline Antikörper & Hersteller \\
\hline Alexa Fluor® 488 goat anti-mouse lgG $(\mathrm{H}+\mathrm{L})$ & Invitrogen $^{\mathrm{TM}}$, Life Technologies \\
$\begin{array}{l}\text { Monoclonal mouse anti-human-BCL6 } \\
\text { (H-12): sc-365618 }\end{array}$ & Santa Cruz ${ }^{\circledR}$ biotechnology \\
\hline
\end{tabular}

\subsubsection{Vektoren}

Tabelle 2.8: Vektoren

\begin{tabular}{ll}
\hline Name & Applikation, Anbieter \\
\hline pcDNA3-BCL6 & $\begin{array}{l}\text { Humaner BCL6 Expressionsvektor, freundlicherweise zur Verfügung } \\
\text { gestellt von Giovanna Roncador, Monoclonal Antibodies Unit Centro } \\
\text { Nacional de Investigaciones Oncológicas, Spanien }\end{array}$ \\
pcDNA3 & $\begin{array}{l}\text { Eukaryotischer Expressionsvektor, hergestellt, indem BCL6-cDNA aus } \\
\text { dem Expressionsvektor pcDNA3-BCL6 entfernt wurde }\end{array}$ \\
\hline
\end{tabular}

\subsubsection{Oligonukleotidprimer}

Tabelle 2.9: Oligonukleotidprimer

\begin{tabular}{|c|c|c|c|c|c|c|}
\hline $\begin{array}{l}\text { Protein } \\
\text { (Gen) }\end{array}$ & Primer & Sequenz $5^{\prime}-3^{\prime}$ & $\begin{array}{l}\text { Produkt- } \\
\text { länge }\end{array}$ & $\begin{array}{l}\text { Annealing } \\
\text { Temperatur }\end{array}$ & Zyklen & Gel \\
\hline GAPDH & $\begin{array}{l}\text { 84_1for } \\
84 \_2 r e v\end{array}$ & $\begin{array}{l}\text { TCACCATCTTCCAG } \\
\text { GAGCG } \\
\text { CTGCTTCACCACCT } \\
\text { TCTTGA }\end{array}$ & $572 b p$ & $56^{\circ} \mathrm{C}$ & 22 & $1,5 \%$ \\
\hline BCL6 & $\begin{array}{l}\text { 108_1for } \\
\text { 108_2rev }\end{array}$ & $\begin{array}{l}\text { CTTCTCAACCTTAAT } \\
\text { CGTCTC } \\
\text { CCGTTTTATGGGCT } \\
\text { CTAAACTG }\end{array}$ & $91 \mathrm{bp}$ & $53^{\circ} \mathrm{C}$ & 30 & $2 \%$ \\
\hline
\end{tabular}

\subsubsection{TaqMan ${ }^{\circledR}$ Genexpressions-Assays}

Die im Folgenden aufgeführten TaqMan® real-time PCR Assays wurden von Applied Biosystem (Foster City, CA, USA) bezogen. 
Tabelle 2.10: Übersicht über die verwendeten TaqMan® Assays mit ihren Spleißvarianten

\begin{tabular}{|c|c|c|}
\hline $\begin{array}{l}\text { Protein } \\
\text { (Gen) }\end{array}$ & Assay & Spleißvariante \\
\hline GAPDH & Hs99999905_m1 & NM_002046.4 \\
\hline BCL6 & Hs00277037_m1 & $\begin{array}{l}\text { NM_001130845.1 } \\
\text { NM_001134738.1 } \\
\text { NM_001706.4 }\end{array}$ \\
\hline $\begin{array}{l}\text { OAT1 } \\
\text { (SLC22A6) }\end{array}$ & Hs00537914_m1 & $\begin{array}{l}\text { NM_004790.4 } \\
\text { NM_153276.2 } \\
\text { NM_153277.2 } \\
\text { NM_153278.2 }\end{array}$ \\
\hline $\begin{array}{l}\text { OAT3 } \\
\text { (SLC22A8) }\end{array}$ & Hs00188599_m1 & $\begin{array}{l}\text { NM_001184732.1 } \\
\text { NM_001184733.1 } \\
\text { NM_001184736.1 } \\
\text { NM_004254.3 }\end{array}$ \\
\hline $\begin{array}{l}\text { OAT10 } \\
\text { (SLC22A13) }\end{array}$ & Hs00188605_m1 & NM_004256.3 \\
\hline $\begin{array}{l}\text { OAT4 } \\
\text { (SLC22A11) }\end{array}$ & Hs00218486_m1 & NM_018484.2 \\
\hline $\begin{array}{l}\text { OCT1 } \\
\text { (SLC22A1) }\end{array}$ & Hs00427554_m1 & NM_003057.2 \\
\hline $\begin{array}{l}\text { OCT2 } \\
\text { (SLC22A2) }\end{array}$ & Hs00533907_m1 & NM_003058.3 \\
\hline $\begin{array}{l}\text { OCT3 } \\
\text { (SLC22A3) }\end{array}$ & Hs00222691_m1 & NM_021977.3 \\
\hline $\begin{array}{l}\text { MDR1 } \\
\text { (ABCB1) }\end{array}$ & Hs00184491_m1 & NM_000927.4 \\
\hline $\begin{array}{l}\text { MRP2 } \\
\text { (ABCC2) }\end{array}$ & Hs00166123_m1 & NM_000392.3 \\
\hline
\end{tabular}




\subsubsection{Software und Online-Datenbanken}

Tabelle 2.11: Software

\begin{tabular}{|c|c|c|}
\hline Programm & Verwendung & Hersteller \\
\hline Axio Vision Rel. 4.6 & Fluoreszenz- Mikroskopie & $\begin{array}{l}\text { Carl Zeiss AG } \\
\text { (Oberkochen, Deutschland) }\end{array}$ \\
\hline GraphPad Prism 4 & $\begin{array}{l}\text { Statistische Überprüfung der } \\
\text { Ergebnisse und Erstellung } \\
\text { der Graphen }\end{array}$ & $\begin{array}{l}\text { GraphPad Software, Inc. } \\
\text { (La Jolla, CA, USA) }\end{array}$ \\
\hline ImageJ 1.44 & Bildbearbeitung & Wayne Rasband \\
\hline Microsoft Office 2007 & Daten- und Textverarbeitung & $\begin{array}{l}\text { Microsoft Corporation } \\
\text { (Redmond, WA, USA) }\end{array}$ \\
\hline $\begin{array}{l}\text { MicroWin } 2000 \text { Version } \\
4.41\end{array}$ & Messung der Fluoreszenz & $\begin{array}{l}\text { Berthold Technologies } \\
\text { (Bad Wildbad, Deutschland) }\end{array}$ \\
\hline MxPro - Mx3000P & real-time PCR & $\begin{array}{l}\text { Agilent Technologies } \\
\text { (Waldbronn, Deutschland) }\end{array}$ \\
\hline
\end{tabular}

Tabelle 2.12: Online-Datenbanken

\begin{tabular}{ll}
\hline Name & Adresse \\
\hline $\begin{array}{l}\text { NCBI (National Center for Biotechnology } \\
\text { Information) }\end{array}$ & http://www.ncbi.nlm.nih.gov/ \\
\hline
\end{tabular}

\subsubsection{Nierenkarzinomzelllinien}

Die in den vorliegenden Untersuchungen verwendeten Nierenkarzinomzellinien 786-O und ACHN wurden von ATCC (LGC Standards GmbH, Wesel, Deutschland) bezogen.

Die untersuchten Zellinien LN78 und RCCNG1 stammen aus Biopsien von Nierenkarzinomen (durchgeführt in der Universitätsmedizin Göttingen, Abteilung Nephrologie und Rheumatologie). Sie wurden dem Institut freundlicherweise von Prof. Dr. Gerhard A. Müller und Prof. Dr. H. Dihazi aus der Abteilung Nephrologie und Rheumatologie, Universitätsmedizin Göttingen zur Verfügung gestellt.

\section{$\underline{\mathrm{ACHN}}$}

ATCC Nummer: $\quad$ CRL-16112

Organismus: Homo sapiens (Zellen eines 22-jährigen kaukasischen Mannes)

Herkunft: Niere 
Erkrankung: $\quad$ Adenokarzinom der Niere (Zellen stammen von der metastasierenden Seite: Pleuraerguss)

Wachstumsverhalten: adhärent

Morphologie: epithelial

\section{LN78}

Organismus: $\quad$ Homo sapiens (Zellen einer 73-jährigen Frau)

Herkunft: Niere

Erkrankung: Klarzellkarzinom der Niere

Wachstumsverhalten: adhärent

Morphologie: $\quad$ epithelial

\section{RCCNG1}

Organismus: Homo sapiens (Mann)

\section{6-0}

ATCC Nummer:

CRL-1932

Organismus: Homo sapiens (Zellen eines 58-jährigen kaukasischen Mannes)

Herkunft: Niere

Erkrankung: Klarzellkarzinom der Niere

Wachstumsverhalten: adhärent

Morphologie: epithelial 


\section{$2.2 \quad$ Methoden}

\subsubsection{Zellkultur}

Die verwendeten Nierenkarzinomzelllinien 786-O, ACHN, LN78 und RCCNG1 wurden unter sterilen Bedingungen in jeweils $10 \mathrm{ml}$ des Kulturmediums Quantum 263 mit Penicillin/Streptomycin ausgesät und im Brutschrank bei $37{ }^{\circ} \mathrm{C}$ und $5 \% \mathrm{CO}_{2}$ kultiviert. Alle drei Tage erfolgte ein Mediumwechsel, die Konfluenz der Zellen wurde alle zwei Tage lichtmikroskopisch kontrolliert. Bei 80-90\% Konfluenz wurden die Zellen passagiert. Zum Passagieren der Zellen wurde das Medium durch Absaugen entfernt, die Zellen mit $10 \mathrm{ml}$ Phosphat-gepufferter Salzlösung (PBS = phosphate buffered saline) gewaschen und

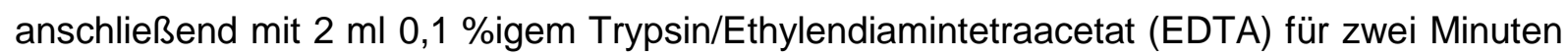
im $\mathrm{CO}_{2}$-Brutschrank bei $37^{\circ} \mathrm{C}$ inkubiert. Nach lichtmikroskopischer Kontrolle des Ablösungsprozesses wurde die Reaktion mit $5 \mathrm{ml}$ Kulturmedium gestoppt und die Zellsuspension mit den gelösten Zellen in ein Röhrchen überführt. Nach dem Zentrifugieren der Zellsuspension für fünf Minuten bei 1.000 Upm bei Raumtemperatur wurde der Überstand verworfen und das Zellpellet mit $1 \mathrm{ml}$ Kulturmedium resuspendiert.

\subsubsection{Bestimmung der Zellzahl}

Vor der weiteren Kultivierung wurde die Zelldichte mithilfe der Neubauer-Zählkammer bestimmt. Dazu wurden die Zellen im Verhältnis 1:10 mit Zellkulturmedium verdünnt. Jeweils $10 \mu \mathrm{l}$ der verdünnten Lösung wurden in die Neubauer-Zählkammer appliziert und lichtmikroskopisch ausgezählt. Die Glaskammer besitzt ein Raster, welches die Kammer in jeweils vier Quadranten einteilt. Jeder Quadrant besteht aus 16 Quadraten. Die aufgetragenen Zellen wurden in jedem einzelnen Quadranten gezählt. Anschließend wurde ein Mittelwert ermittelt. Dieser wurde mit dem Verdünnungs- und Kammerfaktor $\left(10^{5}\right)$ multipliziert. Die Ermittlung der Zellzahl erfolgte nach der folgenden Formel:

$$
\frac{\text { Zellen je Quadrant }}{4} \times \text { Verdünnungsfaktor } 10^{5}=\text { Zellzahl pro ml Zellsuspension }
$$

\subsubsection{Aussaat der Zellen}

Für die Transfektion wurden die Zellen in 24-Well-Zellkulturplatten ausgesät. Vor der Aussaat wurde die Zellzahl bestimmt. Da die ACHN-Zellen nur gering adhärent wachsen, wurden für diese Zelllinie Poly-D-Lysin-beschichtete 24-Well-Zellkulturplatten verwendet. Hierzu wurden die Platten mit einer $1 \%$ igen Poly-D-Lysin-Lösung für zehn Minuten bei Raumtemperatur inkubiert und anschließend bei Raumtemperatur getrocknet. 


\subsubsection{Transfektionstechnik unter Verwendung der Lipofektamin-Methode}

Um zu untersuchen, ob der Transkriptionsfaktor BCL6 einen Einfluss auf die Expressionen verschiedener Transportproteine und die Zytostatika-induzierte Apoptose der Nierenkarzinomzelllinien 786-O, ACHN, LN78 und RCCNG1 hat, wurden die Zellen transient mit BCL6 transfiziert. Die Transfektion wurde mit dem Leervektor pcDNA3 als Kontrolle und dem Expressionsvektor pcDNA3-BCL6 durchgeführt. Am Tag vor der Transfektion wurden die Zellen in einer 24-Well-Zellkulturplatte im Wachstumsmedium ohne Antibiotika ausgesät. Bei einer Konfluenz von etwa 70 \% wurden die Zellen transient transfiziert. Dazu wurden die auf Eis gekühlten Plasmidvektoren pcDNA3 und pcDNA3-BCL6 mit dem Medium DMEM-HG (ohne FCS, ohne Penicillin/Streptomycin) verdünnt. Das Lipofektamin (Lipofectamine ${ }^{\mathrm{TM}}$ 2000, Invitrogen ${ }^{\mathrm{TM}}$ Life Technologies) wurde nach Herstellerangaben mit DMEM-HG verdünnt. Die Lipofektamin-Verdünnung wurde für fünf Minuten bei Raumtemperatur inkubiert und anschließend mit den verdünnten Plasmidlösungen vorsichtig vermischt. Nach 20-minütiger Inkubation bei Raumtemperatur wurden die Zellen mit den LipofektaminPlasmid-Lösungen exponiert. Anschließend wurden die Zellen für vier Stunden in einem $\mathrm{CO}_{2}$-Brutschrank $\left(37^{\circ} \mathrm{C}\right)$ inkubiert. Danach wurde die Lipofektamin-Plasmid-Lösung durch Wachstumsmedium (Quantum 263 mit Penicillin/Streptomycin) ersetzt und die Zellen weitere 43 Stunden kultiviert.

\subsubsection{BCL6-Expressionsanalyse in Nierenkarzinomzelllinien}

Um herauszufinden, ob die BCL6-Transfektion erfolgreich war, wurde untersucht, ob die Zellinien BCL6 exprimieren. Dazu wurden die untersuchten Zellen, wie in Kapitel 2.2.4 beschrieben, entweder mit dem Expressionsvektor für BCL6 (pcDNA3-BCL6) oder mit dem Leervektor (pcDNA3) transfiziert. Im Anschluss wurde die RNA aus den Zellen isoliert und in cDNA umgeschrieben. Danach wurde mittels der PCR-Analyse die Transfektion für jedes Experiment kontrolliert. Zusätzlich wurde mithilfe der Taqman® real-time PCR die Expression von SLC-Transportern quantifiziert.

\subsubsection{Isolierung und Aufreinigung der RNA}

Für die RNA-Isolierung aus den vier Nierenkarzinomzelllinien 786-O, ACHN, LN78 und RCCNG1 wurde das RNeasy ${ }^{\circledR}$ Mini Kit (Qiagen) nach Herstellerangaben verwendet. Das Prinzip dieses Kits basiert auf dem Lysieren und Homogenisieren der Zellproben und dem anschließenden Auffangen der einzelsträngigen RNA auf einer mit Silikon-Gel beschichteten Membran (Chomczynski und Sacchi 1987). Die RNA-Extraktion erfolgte 43 Stunden nach der Transfektion der Zellproben in Reaktionsgefäßen, die vom Hersteller geliefert wurden. 
Die Isolation der RNA wurde für pcDNA3-transfizierte und BCL6-transfizierte Zellen parallel vorgenommen. Alle Schritte erfolgten, wenn nicht anders beschrieben, bei Raumtemperatur. RLT-Puffer aus dem Kit wurde mit $\beta$-Mercatoethanol ( $\beta$-ME) versetzt (Verhältnis: $10 \mu \mathrm{l} \beta-\mathrm{ME}$ zu $1 \mathrm{ml}$ RLT-Puffer), durch Vortexen vermischt und je $150 \mu \mathrm{l}$ dieses Gemisches/Well auf die Zellen pipettiert. Der RLT-Puffer besteht aus hochkonzentriertem Guanidinisothiocaynat. Dieses Salz lysiert Zellen, inaktiviert die RNasen und denaturiert Proteine. Zusätzlich wurden $150 \mu \mathrm{l}$ Ethanol (70\%) auf die Zellproben gegeben, um optimale Bedingungen für die Bindung an die Silikon-Gel-Membran zu schaffen. Dann wurde die mitgelieferte RNeasy Mini-Spinsäule auf einem 2-ml-Auffangröhrchen platziert und das Lysat auf die Säule überführt. Es folgte die Zentrifugation der Proben für 15 Sekunden bei maximaler Geschwindigkeit. Der Durchfluss wurde verworfen. Um reine RNA zu eluiren folgten drei Waschschritte. Dazu wurden $700 \mu \mathrm{l}$ RW1-Waschpuffer und nach dem anschließenden Zentrifugieren für eine Minute zweimal jeweils $500 \mu \mathrm{l}$ PRE-Puffer auf die Säule gegeben und erneut zwei Minuten zentrifugiert, um die Membran zu trocknen. Die Auffangröhrchen wurden verworfen und die Säule auf ein steriles 1,5-ml-Eppendorfgefäß platziert. Im letzten Schritt wurde die gebundene RNA mit $30 \mu \mathrm{l}$ RNase-freiem Wasser von der Säulenmatrix eluiert. Die RNA wurde im Anschluss direkt auf Eis gelagert und die Konzentration photometrisch mithilfe des GeneQuant-Gerätes bestimmt. Die RNA wurde entweder direkt für die reverse Transkription verwendet oder bis zur weiteren Verarbeitung bei $-80{ }^{\circ} \mathrm{C}$ gelagert.

\subsubsection{Reverse Transkription (cDNA-Synthese)}

Gesamt-RNA stellt ein Gemisch aus Transfer-RNA (tRNA), ribosomaler RNA (rRNA) sowie messenger RNA (mRNA, Boten-RNA) dar. In dieser Arbeit wurde als Ausgangsmaterial für die Polymerase-Ketten-Reaktion (polymerase chain reaction, PCR) die zur RNA komplementäre complementary DNA (cDNA) verwendet. Hierzu wurde die aufgereinigte Gesamt-RNA mithilfe des Enzyms reverse Transkriptase in cDNA umgeschrieben. Die verwendete reverse Transkriptase Superscript ${ }^{\circledR}$ II (Invitrogen ${ }^{\mathrm{TM}}$, Life Technologies) ist eine spezielle RNA-abhängige DNA-Polymerase. Die einzelsträngige RNA dient der reversen Transkriptase als Matrize (Template) und wird in einzelsträngige komplementäre cDNA umgeschrieben. Die cDNA-Synthese erfolgte in drei Schritten und nach Empfehlung des Herstellers. Dazu wurden im ersten Schritt je $2 \mu \mathrm{g}$ RNA zu $500 \mathrm{ng} / \mu \mathrm{l}$ Olidonukleotiden als Primer (Oligo-dT-Primer 5'-TTTTTTTTTTTT-3") und 10 mM dNTPs (Desoxyribonukleosidtriphosphate) hinzugefügt. Der Ansatz wurde auf je 13,5 $\mu \mathrm{l}$ mit nukleasefreiem Wasser aufgefüllt. Die Proben wurden zur Denaturierung der RNA in ein Heizgerät (in dieser Arbeit als Thermocycler bezeichnet) gestellt und inkubiert. 
Tabelle 2.13: Temperaturvorgaben Schritt 1: Denaturierung der RNA

\begin{tabular}{lll}
\hline Zeit (Minuten) & Temperatur $\left({ }^{\circ} \mathbf{C}\right)$ & Prozess \\
\hline 5 & 65 & Denaturierung der \\
5 & 4 & Sekundärstruktur der RNA \\
& & Abkühlen \\
\hline
\end{tabular}

Im zweiten Schritt wurden zu jedem Ansatz je $6 \mu$ l Mastermix (Tab. 2.14) pipettiert und die Proben anschließend für zwei Minuten im Thermocycler inkubiert. Bei einer Temperatur von $42{ }^{\circ} \mathrm{C}$ lagerten sich die Oligo-dT-Primer an das 5'-Ende der mRNA an (Annealing).

Tabelle 2.14: Zusammensetzung des Mastermixes für die cDNA-Synthese

\begin{tabular}{ll}
\hline Reagenz & Menge \\
\hline $\mathbf{5}$ x First-Strand Puffer & $4 \mu \mathrm{l}$ \\
$\mathbf{0 , 1}$ M Dithiothreitol (DTT) & $2 \mu \mathrm{l}$ \\
\hline
\end{tabular}

Im letzten Schritt wurde jeder Ansatz mit 0,5 $\mu \mathrm{l}$ Superscript@II versetzt, durch Pipettieren sorgfältig vermischt und die reverse Transkription durchgeführt.

Tabelle 2.15: cDNA-Synthese mit Supercript®II

\begin{tabular}{lll}
\hline Zeit (Minuten) & Temperatur $\left({ }^{\circ} \mathbf{C}\right)$ & Prozess \\
\hline 50 & 42 & cDNA-Synthese \\
15 & 70 & Inaktivierung des Enzyms \\
\hline
\end{tabular}

Die synthetisierte cDNA wurde bis zur weiteren Verarbeitung bei $-20^{\circ} \mathrm{C}$ tiefgefroren.

\subsubsection{Polymerase-Kettenreaktion}

Die PCR erlaubt die enzymatische Amplifikation, also die Vervielfältigung bestimmter Nukleotidsequenzen. Das Prinzip dieser Methode ist die zyklische Wiederholung der jeweiligen Reaktionsschritte, bei der die Produkte der vorangegangenen Zyklen die Ausgangsprodukte für den nächsten Reaktionszyklus darstellen. Die neu gebildeten DNAStränge dienen in den folgenden Zyklen demnach wieder als Matrizen. Auf diese Weise wird der Matrizenstrang exponentiell amplifiziert. Für die in diesen Experimenten angewandte PCR-Analyse wurden neben dem zu vervielfältigendem DNA-Abschnitt (Template) die aus dem hitzestabilen Bakterienstamm Thermus aquaticus isolierte DNA-Polymerase (TaqPolymerase), zwei spezifische, einzelsträngige Oligonukleotide (Primer) sowie dNTPs benötigt. 
Ein typischer PCR-Zyklus besteht aus drei Schritten:

1. Denaturierung

2. Annealing (= Hybridisierung der Primer)

3. Elongation: Amplifikation des DNA-Abschnitts in $5^{\prime} \rightarrow 3^{\prime}$ - Richtung

Während des Denaturierungsschrittes wird der zu amplifizierende DNA-Doppelstrang durch Erhitzen in zwei Einzelstränge getrennt. Beim Annealing-Schritt ermöglicht das Abkühlen die Hybridisierung der im Überschuss zugegebenen spezifischen Oligonukleotidprimer mit dem gewünschten Genabschnitt der komplementären DNA-Matrize. Im letzten Schritt erfolgt die eigentliche DNA-Synthese. Dazu wird die Temperatur auf das Temperaturoptimum der spezifischen DNA-Polymerase erhöht, wodurch beide Primer in $5^{\prime} \rightarrow 3^{\prime}$ - Richtung elongiert werden. Dieser Zyklus wird 20 bis 30 Mal wiederholt, was einem Amplifikationsfaktor von $10^{6}$ bzw. $10^{7}$ entspricht.

\subsection{PCR-Analyse}

Die Polymerase-Kettenreaktion diente in der vorliegenden Arbeit der Qualitätskontrolle der reversen Transkription. In einem 0,5-ml-Eppendorfgefäß wurden $48 \mu \mathrm{l}$ Mastermix angesetzt (siehe Tab. 2.16). Der Mastermix wurde mit $2 \mu \mathrm{l}$ cDNA versetzt. Für die Negativkontrolle wurde die cDNA durch Wasser ersetzt. Der Mastermix wurde mit der cDNA-Probe vermischt und anschließend die PCR im Thermocycler nach dem Schema der Tab. 2.17 durchgeführt.

Tabelle 2.16: Mastermix-Zusammensetzung für die Standard-PCR

\begin{tabular}{lc}
\hline Reagenz & Volumen \\
\hline PCR-Puffer (10 x) & $5 \mu \mathrm{l}$ \\
Forward Primer (20pmol) & $1 \mu \mathrm{l}$ \\
Reverse Primer (20 pmol) & $1 \mu \mathrm{l}$ \\
dNTPs (jeweils 1,25 mM) & $3 \mu \mathrm{l}$ \\
Taq-Polymerase & $2 \mu \mathrm{l}$ \\
$\mathrm{H}_{2} \mathrm{O}$ & $31 \mu \mathrm{l}$ \\
\hline
\end{tabular}

Tabelle 2.17: Thermocycler-Programm für die Standard-PCR

\begin{tabular}{|c|c|c|c|}
\hline Zyklenzahl & Temperatur $\left({ }^{\circ} \mathrm{C}\right)$ & Zeit & Schritt \\
\hline 1 & 94 & $2 \min$ & initiale Denaturierung \\
\hline & 94 & 40 sek & Denaturierung \\
\hline 22 & $\begin{array}{l}56 \\
72\end{array}$ & $\begin{array}{l}50 \text { sek } \\
50 \text { sek }\end{array}$ & $\begin{array}{l}\text { Annealing } \\
\text { Elongation }\end{array}$ \\
\hline 1 & 72 & $10 \mathrm{~min}$ & finale Elongation \\
\hline
\end{tabular}




\subsubsection{Agarosegel-Elektrophorese}

Die Methode der Gelelektrophorese ist ein Trennungsverfahren, um DNA-Fragmente abhängig von ihrer Größe aufzutrennen und zu identifizieren (Mülhardt 2009). Dabei wird Agarosegel als Trägermedium verwendet, welches eine Art Siebstruktur aufweist.

Die negativ geladene DNA wird auf das Gel gegeben und anschließend wird ein elektrisches Feld angelegt. Innerhalb des elektrischen Feldes bewegen sich die DNA-Fragmente von der negativ geladenen Kathode je nach Größe und Ladung der Moleküle mit unterschiedlicher Geschwindigkeit zur positiv geladenen Anode. Da die Poren des Agarosegels für kleinere Fragmente weniger Widerstand darstellen, durchlaufen kurze DNA-Fragmente das Agarosegel schneller als längere Fragmente. Zur Überprüfung des 572 bp-PCR-Produktes (Glycerinaldehyd-3-Phosphat-Dehydrogenase, GAPDH) wurde ein 1,5\%iges Agarosegel herstellt, zur Überprüfung des 91-bp-PCR-Produktes (BCL6) ein $2 \%$ iges Agarosegel. Agarose wurde dafür in 0,5 x TBE-Puffer (Tris-Borat-EDTA-Puffer) gelöst und in der Mikrowelle erhitzt. Um die DNA im Gel sichtbar zu machen wurden $0,5 \mu \mathrm{g} / \mathrm{ml}$ Ethidiumbromid hinzugegeben. Das auspolymerisierte Agarosegel wurde in eine mit Elektrophoresepuffer (0,5 x TBE) gefültte Elektrophoresekammer gelegt. Die DNA-Fragmente wurden mit DNA Stopp vermischt und in die Geltaschen pipettiert. Dann wurde eine Spannung von $110 \mathrm{~V}$ angelegt und für 40-60 Minuten aufrechterhalten. Danach wurde das Ergebnis unter UV-Licht betrachtet und fotografiert.

\subsubsection{Quantitative TaqMan® real-time PCR}

Die quantitative real-time PCR ermöglicht die semi-quantitative Bestimmung der mRNAExpressionsspiegel. Diese Methode wird auch Echtzeit-PCR genannt, da im Gegensatz zur Standard-PCR die Detektion bereits während der Amplifikation stattfindet. Bei jedem realtime PCR-Zyklus wird das gewünschte Transkript verdoppelt. In dieser Arbeit wurde die realtime PCR nach dem TaqMan-Prinzip mit TaqMan®-Gene expression Assays (in dieser Arbeit als TaqMan®-Primer bezeichnet) durchgeführt. TaqMan®-Primer sind Oligonukleotide, welche sequenzspezifisch an komplementäre cDNA-Sequenzen binden und an die zwei Fluoreszenzfarbstoffe gebunden sind. Die Fluoreszenzfarbstoffe emittieren in Gegenwart einer Lichtquelle Licht. Das 5'-Ende der Sonden ist mit dem Reporterfarbstoff 6FAM $^{\text {TM }}$ (6-Carboxy-Fluorescein) belegt, das 3“-Ende mit dem Quencherfarbstoff TAMRA ${ }^{\mathrm{TM}}$ (6-Carboxy-Tetramethyl-Rhodamin). Die Methode macht sich den Fluoreszenz-ResonanzEnergie-Transfer (FRET) zunutze. Die Fluoreszenz des Reportferfarbstoffes wird durch den Quencherfarbstoff unterdrückt. Die TaqMan®-Primer binden während der real-time PCR an die DNA. Trifft die Taq-Polymerase während der Extensionsphase auf die spezifisch gebundene TaqMan-Sonde, so hydrolysiert die 5'-3'-Exonuklease-Aktivität der Polymerase die Sonde und trennt dabei den Reporter- vom Quencherfarbstoff. Daraus resultiert, dass die 
Fluoreszenzfarbstoffe des Reporters freigesetzt werden und Fluoreszenz emittieren. Die Lichtstärke korreliert mit der Menge freigesetzter Fluoreszenzfarbstoffe und demnach mit der Menge der vervielfältigten DNA. Die Messung der Fluoreszenz findet am Ende der Elongation in jedem Zyklus statt. Ein Zyklus der TaqMan® real-time PCR besteht aus folgenden Schritten:

- Denaturierung

- Annealing (= Hybridisierung der Primer)

- Elongation des zweiten DNA-Stranges mittels der Taq-Polymerase

Die eingesetze Taq-Polymerase hat eine Synthese- und eine Exonukleaseaktivität. Der Reaktionsansatz der TaqMan® real-time PCR setzte sich wie folgt zusammen:

Tabelle 2.18: Reaktionsansatz der TaqMan® real-time PCR

\begin{tabular}{ll}
\hline Reagenz & Volumen \\
\hline Reaktionspuffer (TaqMan@-Mastermix) $(2 \mathbf{x})$ & $10 \mu \mathrm{l}$ \\
TaqMan-Primer (20 x) & $1 \mu \mathrm{l}$ \\
cDNA-Probe & $1 \mu \mathrm{l}$ \\
$\mathrm{H}_{2} \mathrm{O}$ & $8 \mu \mathrm{l}$ \\
\hline
\end{tabular}

Pro Experiment wurden jeweils zwei Proben eines Transporters untersucht. Zusätzlich zu den zu untersuchenden Proben wurden pro Zelllinie auch jeweils zwei Proben des Referenzgens GAPDH sowie des Gens BCL6 untersucht. Die hergestellten Reaktionsansätze wurden in den real-time PCR-Thermocycler überführt und die real-time PCR bei dem in Tab. 2.19 angegebenen Temperatur-Zeit-Profil durchgeführt.

Tabelle 2.19: Bedingungen der TaqMan® real-time PCR

\begin{tabular}{lcc}
\hline Temperatur $\left({ }^{\circ} \mathbf{C}\right)$ & Zeit & Zyklenanzahl \\
\hline 50 & $2 \mathrm{~min}$ & 1 \\
95 & $10 \mathrm{~min}$ & 1 \\
95 & $15 \mathrm{sek}$ & 40 \\
60 & $1 \mathrm{~min}$ & 40 \\
\hline
\end{tabular}

Als Maß für die Quantifizierung der mRNA der untersuchten Gene ist der CT-Wert (cycle of threshold) von Bedeutung. Der CT-Wert entspricht der Anzahl von PCR-Zyklen die mindestens nötig sind, um ein konstantes Fluoreszenzniveau zu erreichen, welches sich vom Hintergrundrauschen unterscheidet (Pfaffl 2004). Niedrig exprimierte Gene benötigen mehr Zyklen zum Erreichen des CT-Wertes als höher exprimierte Gene. Die Auswertung der realtime PCR basiert auf der $\triangle C T$ Methode ( $\triangle C T=C T$ Zielgen $-C T$ Rerenzgen GAPDH). 
Dabei wird für jede untersuchte Probe der CT-Wert eines eingesetzten Referenzgens („Haushaltsgen“, housekeeping gene) vom CT-Wert des zu untersuchenden Gens subtrahiert. Als Referenzgen wurde GAPDH verwendet. Von diesem Gen kann eine konstante Expressionsmenge in allen untersuchten Proben vorausgesetzt werden.

\subsubsection{Immunfluoreszenz}

Für die Immunfluoreszenzfärbung wurden die 24-Well-Platten mit je einem Glasplättchen/Well belegt und mit Poly-D-Lysin beschichtet. Anschließend wurden die Zellen im Wachstumsmedium ohne Antibiotika kultiviert. Danach wurden die Zellen entweder mit dem Kontrollvektor pcDNA3 oder mit dem Expressionsvektor pcDNA3-BCL6 transfiziert. Die Transfektion wurde, wie in Kapitel 2.2.4 beschrieben, durchgeführt. 48 Stunden nach der Transfektion wurden die Zellen fixiert. Hierzu wurden die Zellen zweimal mit je $1 \mathrm{ml}$ PBS/Well gewaschen und anschließend für acht Minuten bei Raumtemperatur mit je $1 \mathrm{ml}$ 3,7\%iger Formaldehyd-Lösung (in PBS) pro Well fixiert. Danach wurden die Zellen erneut zweimal mit je $1 \mathrm{ml}$ PBS/Well gewaschen. Alle weiteren Schritte erfolgten ebenfalls bei Raumtemperatur. Nach der Fixierung wurden die Zellen für fünf Minuten mit je $1 \mathrm{ml} /$ Well

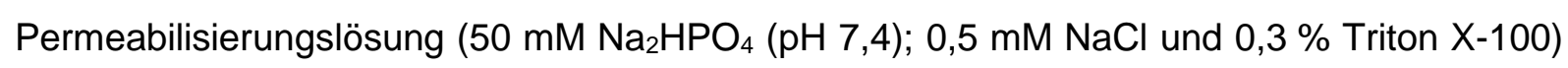
permeabilisiert. Anschließend wurden die Zellen erneut dreimal mit je $1 \mathrm{ml}$ PBS/Well gewaschen. Die fixierten und permeabilisierten Zellen wurden im Anschluss mit Antikörpern und dem Fluoreszenzfarbstoff, jeweils mit PBS und 0,1\% bovinem Serumalbumin (BSA) verdünnt, inkubiert. Im ersten Schritt wurden die Zellen mit $150 \mu \mathrm{l} /$ Well von $1 \mu \mathrm{g} / \mathrm{ml}$ Primärantikörper monoclonal-mouse-anti-BCL6 (Santa Cruz) für zwei Stunden bei Raumtemperatur und unter Schütteln bei ca. 250 Upm inkubiert. Nach der Inkubation erfolgten drei Waschschritte mit je $500 \mu \mathrm{l}$ PBS/Well für jeweils 15 Minuten. Im Anschluss wurden die Zellen mit $150 \mu$ der $1 \%$ igen PBS-BSA-Lösung/Well für 15 Minuten inkubiert, um unspezifische Bindungen zu blockieren. Dann wurde der verdünnte Sekundärantikörper Alexa Fluor® 488 goat anti-mouse lgG $(\mathrm{H}+\mathrm{L})$ (Invitrogen ${ }^{\mathrm{TM}}$ Life Technologies) in die Wells gegeben und die Zellen eine Stunde abgedunkelt inkubiert. Nach einer Stunde folgten drei Waschschritte mit je $500 \mu \mathrm{l}$ PBS/Well für jeweils 15 Minuten. Die letzte Anfärbung erfolgte durch Inkubation der Zellen mit je $300 \mu \mathrm{l}$ von 300 nM des Fluoreszenzfarbstoffs 4',6Diamidino-2-Phenylindol (DAPI, Invitrogen ${ }^{\mathrm{TM}}$ Life Technologies) für drei Minuten im Dunkeln. Abschließend wurden die Zellen dreimal mit je $500 \mu$ I PBS 15 Minuten gewaschen, bevor sie auf Objektträgern fixiert wurden. Die mikroskopische Analyse erfolgte mithilfe eines Fluoreszenzmikroskops (Axio Observer D1, Carl Zeiss AG). BCL6 wurde mit einer Wellenlänge von $488 \mathrm{~nm}$ angeregt, DAPI bei $365 \mathrm{~nm}$. Als Immersionsflüssigkeit diente Immersol ${ }^{\mathrm{TM}} 518 \mathrm{~F}$ (Carl Zeiss AG). Die Auswertung der Transfektionseffizienz erfolgte unter 200-facher Vergrößerung. Mit dem Programm ImageJ 1.44 wurden die mit DAPI angefärbten 
(blauen) Zellkerne gezählt und als $100 \%$ gesetzt. Dann wurden die mit BCL6-transfizierten angefärbten (grünen) Zellkerne ermittelt und diese Anzahl im Verhältnis zu den blau angefärbten Zellkernen bestimmt:

$$
\frac{\text { BCL6 - positive Zellkerne } \times 100}{\text { DAPI - positive Zellkerne }}
$$

\subsubsection{Untersuchung der Caspase-3-Aktivität}

$\mathrm{Zu}$ den morphologischen Merkmalen des programmierten Zelltodes gehören die Schrumpfung der Zellen, die nukleäre Fragmentierung, die Chromatin-Kondensation, die DNA-Fragmentierung und der Zerfall der Plasmamembran. Zu den wichtigsten Enzymen der Apoptose gehören Caspasen. Dabei handelt es sich um aspartatspezifische Cysteinproteasen. Diese Cysteinyl-Aspartasen spalten die Peptidbindungen C-terminal vom Aspartat ab. Initiatorcaspasen wie z.B. die Caspase 2 und 8 initiieren die Apoptose und aktivieren die Caspase 3 und 7. Aktivierte Caspase 3 dient als Nachweis für die induzierte Apoptose. Dieser Nachweis wurde in den durchgeführten Experimenten mit dem EnzChek® Caspase-3 Assay Kit \#2 (Molecular Probes) durchgeführt. Dazu wurden die Zellen 48 Stunden nach der Transfektion mit unterschiedlichen Konzentrationen von 5-Fluorouracil, Irinotecan und Oxaliplatin für 16 Stunden inkubiert. Dann wurden die Zellen mit $500 \mu \mathrm{l}$ PBS/Well gewaschen, mit $200 \mu \mathrm{l}$ Trypsin/Well abgelöst und anschließend zentrifugiert (drei Minuten, 300 x g, Raumtemperatur). Der Überstand wurde verworfen und die Zellen sofort bei $-80^{\circ} \mathrm{C}$ eingefroren. Zur Analyse der Caspaseaktivität wurden die Zellen abgetaut und mit je $70 \mu \mathrm{l}$ Lysepuffer inkubiert. Zur optimalen Lyse wurden die Zellen dreimal im flüssigen Stickstoff eingefroren und abgetaut und anschließend fünf Minuten zentrifugiert. Das weitere Vorgehen erfolgte nach Herstellerangaben. Mithilfe der Software Microwin 2000 Version 4.41 wurde die Fluoreszenz im Mikroplattenleser Mithras LB 940 ermittelt. Im Anschluss erfolgte die Quantifizierung der Proteinkonzentration nach Bradford (siehe Kapitel 2.2.7). Die ermittelte Fluoreszenz wurde zum Gesamtproteingehalt in Verhältnis gesetzt.

\subsubsection{Proteinbestimmung nach Bradford}

Die Proteinkonzentration wurde mithilfe der Methode nach Bradford ermittelt (Bradford, 1976). Die Methode ermöglicht die gleichmäßige Aufladung von Proteinmengen einer Probe. Das Verfahren basiert auf der Komplexbildung des Triphenylmethan-Farbstoffs CoomassieBrilliant-Blau mit Proteinen. Durch diese Reaktion entsteht ein anionischer, blauer Farbstoff und eine daraus folgende Veränderung des Absorptionsmaximums des Farbstoffs von $495 \mathrm{~nm}$ in der ungebundenen Form zu $595 \mathrm{~nm}$ in der gebundenen Form. In die Wells einer 96-Well-Platte wurden je $5 \mu \mathrm{l}$ der zu untersuchenden Probe pipettiert und im Verhältnis 1:5 
mit PBS verdünnt. Jede Probenlösung wurde mit je $200 \mu$ l Bradfordlösung gemischt, welche zuvor im Verhältnis 1:4 mit destilliertem Wasser verdünnt wurde. Zur Kalibrierung wurde eine Standardkurve mit den folgenden aufsteigenden Konzentrationen von bovinem Serumalbumin (BSA) in PBS erstellt: $50 \mu \mathrm{g} / \mathrm{ml}, 100 \mu \mathrm{g} / \mathrm{ml}, 200 \mu \mathrm{g} / \mathrm{ml}, 300 \mu \mathrm{g} / \mathrm{ml}, 400 \mu \mathrm{g} / \mathrm{ml}$, $500 \mu \mathrm{g} / \mathrm{ml}, 750 \mu \mathrm{g} / \mathrm{ml}$. Die Standardlösung wurde ebenso mit $200 \mu \mathrm{l}$ der Bradfordlösung vermischt. Nach zehn Minuten Inkubation bei Raumtemperatur wurde die Absorption photometrisch bei $595 \mathrm{~nm}$ im Mikroplattenleser mit der Software Microwin 2000 Version 4.41 gemessen. Für die Probenlösung und die Standardlösung wurden Doppelbestimmungen gemessen.

\subsubsection{Statistische Auswertungen}

Die statistische Analyse der real-time PCR-Daten und der Ergebnisse aus dem Apoptose Assay erfolgte mittels der GraphPad Prism-Software (Version 4).

Die Messdaten sind Mittelwerte \pm Standardfehler (SEM) aus vier bis fünf unabhängigen Experimenten. Die statistische Analyse der gemessenen Werte erfolgte für den Vergleich von zwei unabhängigen Proben durch den zweiseitigen ungepaarten t-Test (unpaired t-Test). Um signifikante Unterschiede zwischen mehreren Versuchsgruppen und einer Kontrollgruppe zu überprüfen, wurden die Daten mittels one-way ANOVA mit dem Dunnett's multiple comparison-Test analysiert. 


\section{Ergebnisse}

\subsection{Zellmorphologie und -wachstum}

Die lichtmikroskopischen Aufnahmen der Zelllinien 786-O, ACHN, LN78 und RCCNG1 zeigen deutliche Unterschiede in der Morphologie (Abb. 3.1 A-D). Die Zellen der Karzinomzellinie 786-O wachsen spindelförmig mit zum Teil langen Ausläufern, die Zellen der Zelllinien ACHN, LN78 sowie RCCNG1 eher polygonal mit rundem Zellkörper. Die Zelllinie RCCNG1 zeigt zum Teil lange Ausläufer, bevor sie die $100 \%$ ige Zelldichte erreicht. Die Zellen der Zelllinien ACHN und LN78 sind kleiner als die Zellen der Zelllinien 786-O und RCCNG1. Während die Zellen der Zelllinie 786-O eher in lockeren Zellverbänden wachsen, weisen die Zellen der Nierenkarzinomzellinien ACHN, LN78 und RCCNG1 ein dichteres Zellwachstum auf.
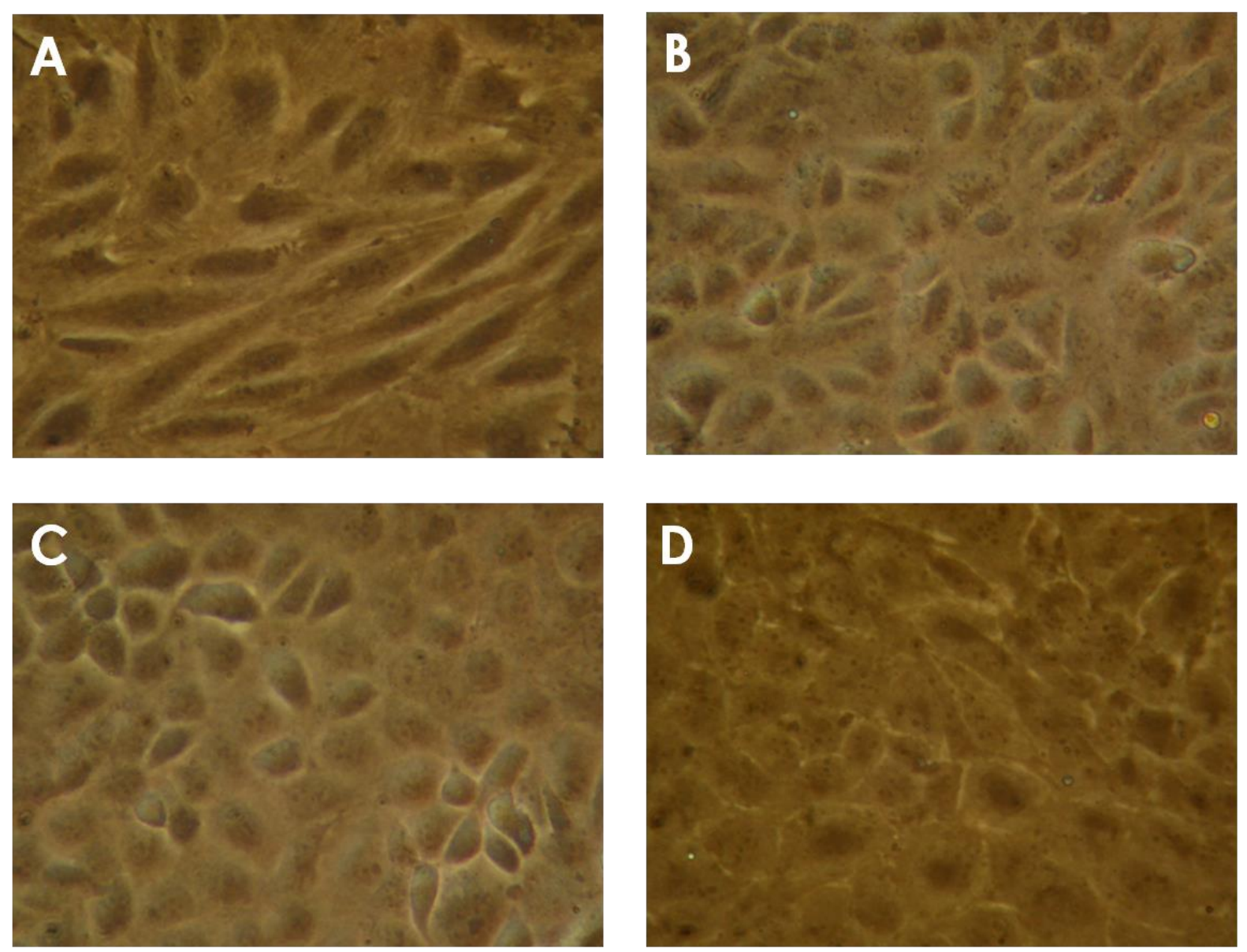

Abbildung 3.1: Lichtmikroskopische Aufnahmen der Zelllinien (A) 786-O, (B) ACHN, (C) LN78, (D) RCCNG1.

Die Nierenkarzinomzelllinien wurden im Zellkulturmedium Quantum 263 mit Penicillin/Streptomycin ausgesät und in einem $\mathrm{CO}_{2}$-Brutschrank bei $37^{\circ} \mathrm{C}$ kultiviert. 100 -fache Vergrößerung. 


\subsection{Nachweis des BCL6-Gens in Nierenkarzinomzelllinien}

Die Zellinien 786-O, ACHN, LN78 und RCCNG1 wurden entweder mit dem Expressionsvektor für BCL6 (pcDNA3-BCL6) oder mit dem Leervektor (pcDNA3) transfiziert. Anschließend wurde die RNA aus den Zellen isoliert und in cDNA umgeschrieben. Mithilfe einer PCR-Analyse wurde die Transfektion für jedes Experiment kontrolliert. Die Höhe der Banden an der DNA-Leiter trifft auf die errechneten Größen der angewandten Primer von 572 Basenpaaren (bp) für das verwendete Haushaltsgen GAPDH und 91 bp für das BCL6Gen zu. Für jede Zelllinie wurde das Experiment fünfmal in unabhängigen Versuchen durchgeführt. Das bedeutet, dass die Experimente mit Nierenkarzinomzellinien in verschiedenen Zell-Passagen durchgeführt wurden.

\subsubsection{Nachweis des BCL6-Gens in der Zelllinie 786-O}

Nach der Transfektion mit pcDNA3-BCL6 wurde das BCL6-Gen in der Zelllinie 786-O erfolgreich überexprimiert (siehe Abb. 3.2). BCL6 wurde in dieser Zelllinie auch endogen exprimiert, wenngleich die Bande für die pcDNA3-transfizierten Kontrollzellen nur schwach detektiert wurde.

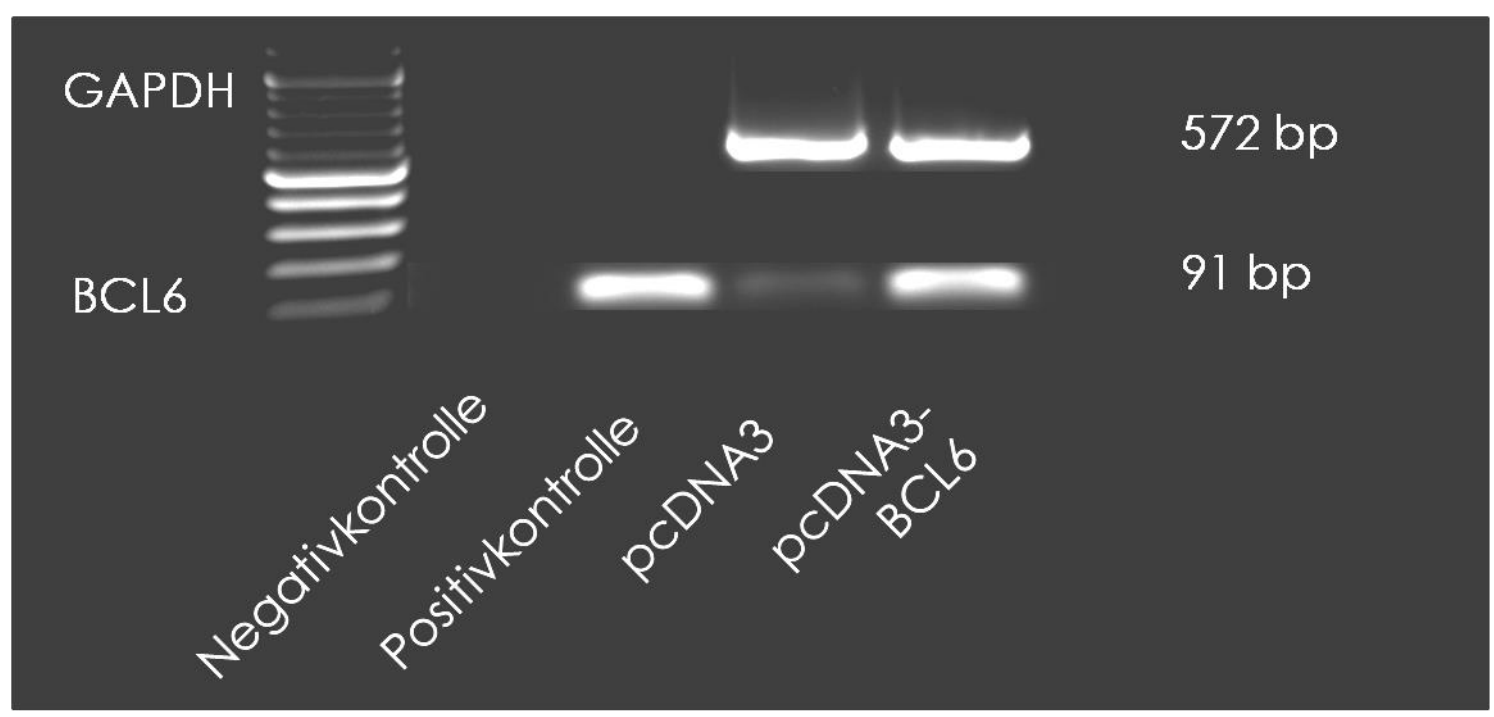

Abbildung 3.2: Nachweis des BCL6-Gens in der Zelllinie 786-O.

Die einzelnen PCR-Produkte wurden mittels Gel-Elektrophorese aufgetrennt und mithilfe von Ethidiumbromid detektiert. Die Abbildung zeigt ein repräsentatives Experiment aus einer Serie von fünf unabhängigen Versuchen. Negativkontrolle = Leerwert $\left(\mathrm{H}_{2} \mathrm{O}\right)$; Positivkontrolle = BCL6-Plasmid; pcDNA3 = mit Leervektor transfizierte Zellen; pcDNA3-BCL6 = mit BCL6-Expressionsplasmid transfizierte Zellen. 


\subsubsection{Nachweis des BCL6-Gens in der Zelllinie ACHN}

Das Expressionsplasmid pcDNA3-BCL6 wurde, wie in Abb. 3.3 dargestellt, in der Zelllinie ACHN erfolgreich transfiziert. Die Abbildung zeigt, dass ACHN-Zellen BCL6 auch endogen exprimieren.

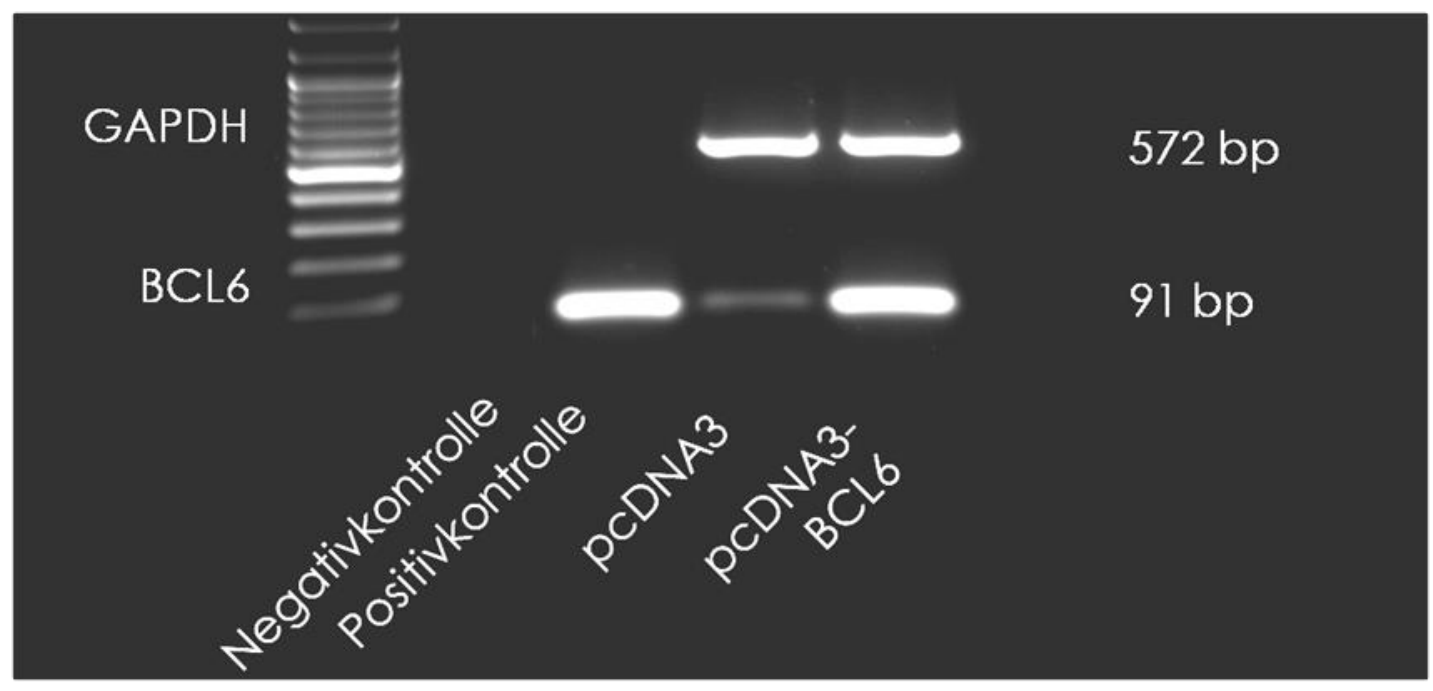

Abbildung 3.3: Nachweis des BCL6-Gens in der Zelllinie ACHN.

Die einzelnen PCR-Produkte wurden mittels Gel-Elektrophorese aufgetrennt und mithilfe von Ethidiumbromid detektiert. Die Abbildung zeigt ein repräsentatives Experiment aus einer Serie von fünf unabhängigen Versuchen. Negativkontrolle = Leerwert $\left(\mathrm{H}_{2} \mathrm{O}\right)$; Positivkontrolle = BCL6-Plasmid; pcDNA3 = mit Leervektor transfizierte Zellen; pcDNA3-BCL6 = mit BCL6-Expressionsplasmid transfizierte Zellen.

\subsubsection{Nachweis des BCL6-Gens in der Zelllinie LN78}

Wie die Abb. 3.4 zeigt, ist das BCL6-Gen nach der Transfektion in der Nierenkarzinomzelllinie LN78 nachweisbar. Die endogene BCL6-Expression konnte auch in dieser Nierenkarzinomzelllinie nachgewiesen werden.

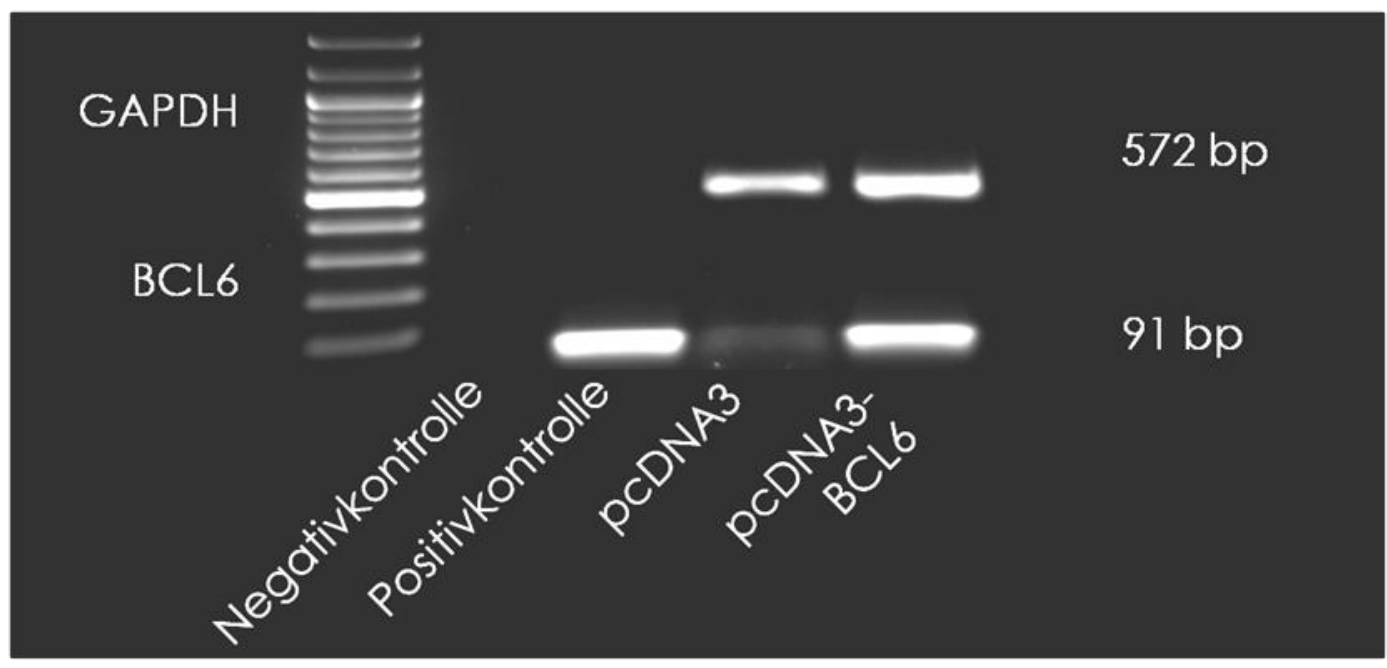

Abbildung 3.4: Nachweis des BCL6-Gens in der Zelllinie LN78. 
Die einzelnen PCR-Produkte wurden mittels Gel-Elektrophorese aufgetrennt und mithilfe von Ethidiumbromid detektiert. Die Abbildung zeigt ein repräsentatives Experiment aus einer Serie von fünf unabhängigen Versuchen. Negativkontrolle = Leerwert $\left(\mathrm{H}_{2} \mathrm{O}\right)$; Positivkontrolle = BCL6-Plasmid; pcDNA3 = mit Leervektor transfizierte Zellen; pcDNA3-BCL6 = mit BCL6-Expressionsplasmid transfizierte Zellen.

\subsubsection{Nachweis des BCL6-Gens in der Zelllinie RCCNG1}

Durch die Transfektion mit dem Transkriptionsfaktor pcDNA3-BCL6 wurde BCL6 in der Zelllinie RCCNG1 überexprimiert (siehe Abb. 3.5). Eine endogene BCL6-Expression wurde auch in den RCCNG1-Zellen nachgewiesen.

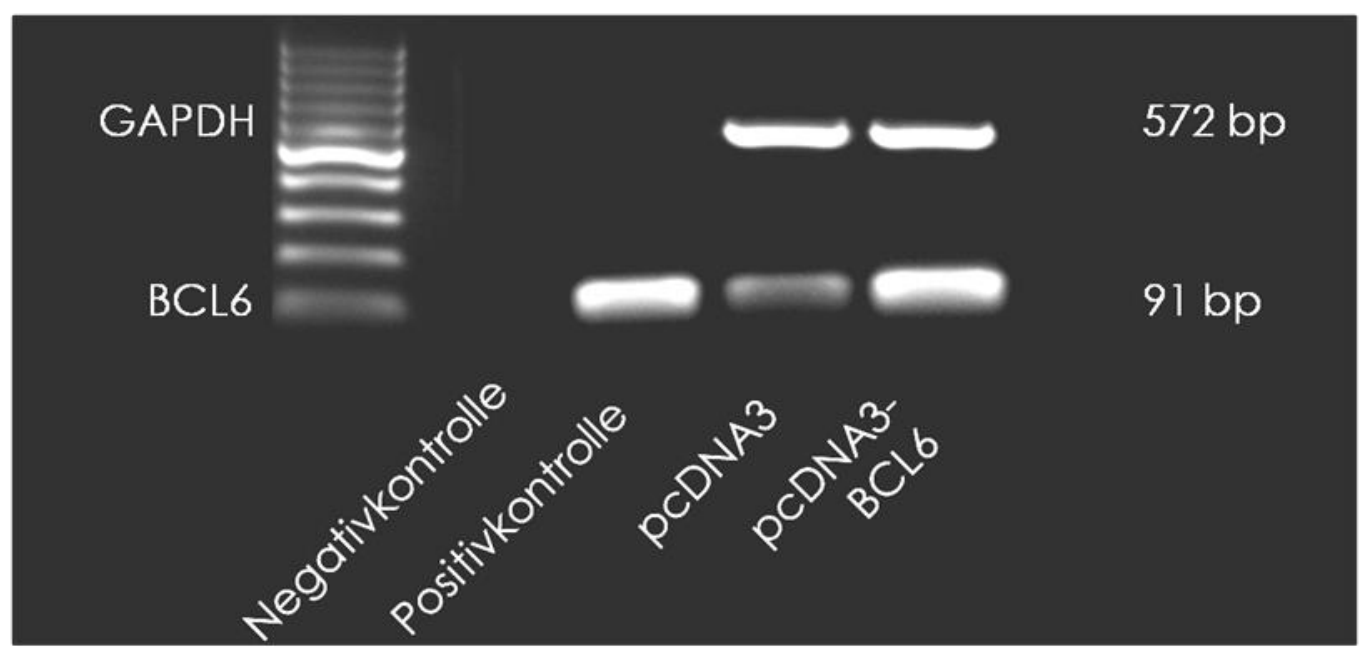

Abbildung 3.5: Nachweis des BCL6-Gens in der Zelllinie RCCNG1.

Die einzelnen PCR-Produkte wurden mittels Gel-Elektrophorese aufgetrennt und mithilfe von Ethidiumbromid detektiert. Die Abbildung zeigt ein repräsentatives Experiment aus einer Serie von fünf unabhängigen Versuchen. Negativkontrolle $=$ Leerwert $\left(\mathrm{H}_{2} \mathrm{O}\right)$; Positivkontrolle $=$ BCL6-Plasmid; pcDNA3 $=$ mit Leervektor transfizierte Zellen; pcDNA3-BCL6 = mit BCL6-Expressionsplasmid transfizierte Zellen.

\subsection{Expression von SLC-Transportern und ABC-Transportern in}

\section{Nierenkarzinomzelllinien}

In den Nierenkarzinomzelllinien 786-O, ACHN, LN78 und RCCNG1 wurde mittels quantitativer real-time PCR die mRNA-Expression der Transportproteine untersucht. Die überprüften Proben der Abbildungen 3.2 - 3.5 wurden als Ausgangsmaterial für die real-time PCR-Analyse eingesetzt. Jede Probe wurde in der real-time PCR-Analyse doppelt bestimmt. Aus den einzelnen Amplifikationskurven wurden mithilfe der Software MxPro CT-Werte errechnet. Die Intravarianz der einzelnen CT-Werte lag stets unter $5 \%$. Der CT-Wert gibt jeweils die Zyklenanzahl der PCR an, welche erforderlich ist, damit ein Fluoreszenzsignal detektiert werden kann. Das bedeutet, je niedriger ein Gen exprimiert ist, umso mehr PCRZyklen sind erforderlich, um das Gen zu detektieren. Der $\Delta$ CT-Wert gibt die Differenz zwischen dem untersuchten Gen und dem Haushaltsgen GAPDH an. Für die real-time PCR 
wurden ausschließlich TaqMan $®$-Primer verwendet, die spezifisch an die mRNA der untersuchten Gene binden.

\subsubsection{GAPDH-Expression unter Einfluss der BCL6-Überexpression}

Zur Kontrolle, ob das Haushaltsgen GAPDH tatsächlich konstant in allen Zellen exprimiert und durch die Transfektion der Zellen mit pcDNA3-BCL6 nicht beeinflusst wurde, diente das folgende Experiment. Dabei wurden aus jeder real-time PCR-Analyse die CT-Werte des Haushaltsgens zwischen BCL6- und Leervektor-transfizierten Zellen verglichen. Wie die Abbildung 3.6 zeigt, änderte sich GAPDH unter BCL6-Transfektion nicht signifikant. Es sind keine signifikanten Unterschiede zwischen pcDNA3-transfizierten Zellen (graue Balken) und pcDNA3-BCL6-transfizierten Zellen (schwarze Balken) nachweisbar. Demzufolge konnte man die GAPDH-Expression für die nachfolgenden Experimente als konstant betrachten.

\section{GAPDH-Expression}

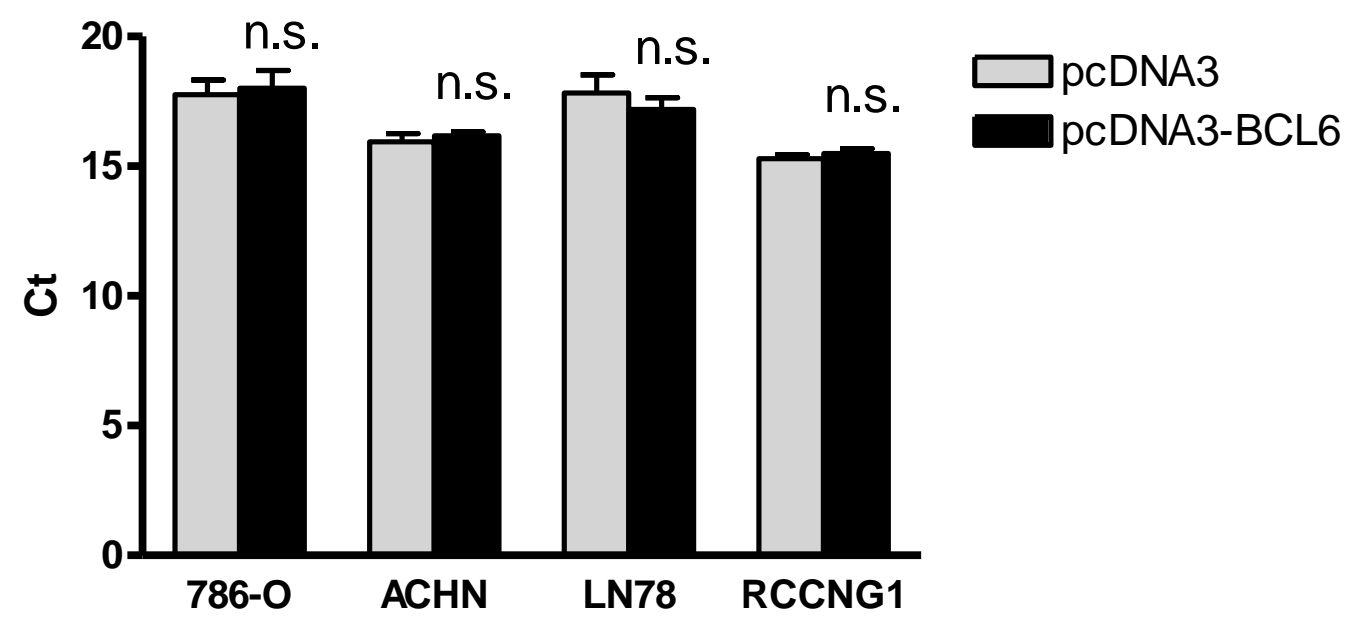

Abbildung 3.6: GAPDH-Expression in den Zellinien 786-O, ACHN, LN78 und RCCNG1 unter Einfluss der BCL6-Überexpression.

Die Zelllinien 786-O, ACHN, LN78 und RCCNG1 wurden entweder mit pcDNA3-BCL6 oder mit dem Kontrollvektor pcDNA3 transfiziert. Die Daten wurden dargestellt als Mittelwert \pm S.E.M.; $n=4$. Statistische Analyse durch unpaired t-Test. n.s. = nicht signifikant.

In den folgenden Säulendiagrammen (Abb. 3.7 - 3.10) wird die Genexpression der unterschiedlich transfizierten Zellen verglichen. Die Ergebnisse der real-time PCR-Analyse von OATs, OCTs und von ausgewählten ABC-Transportern (MDR1 und MRP2) in den Zelllinien 786-O, ACHN, LN78 und RCCNG1 werden im Folgenden einzeln dargestellt. 


\subsubsection{OATs und OCT1 in $786-O$}

Die real-time PCR zeigte, dass durch die Transfektion der Zellen der Nierenkarzinomzelllinie 786-O mit dem Expressionsplasmid pcDNA3-BCL6 die Expression von BCL6 in der Zelllinie 786-O signifikant erhöht wurde (Abb. 3.7). Die Transporter OAT4, OAT10 und OCT1 wurden in der Zelllinie 786-O nachgewiesen. Die mRNA-Spiegel von OAT4, OAT10 und OCT1 wurden in der Nierenkarzinomzelllinie 786-O durch die BCL6-Überexpression nicht beeinflusst. OAT1 und OAT3 wurden ebenso untersucht, waren jedoch in keinem Versuch zu detektieren.

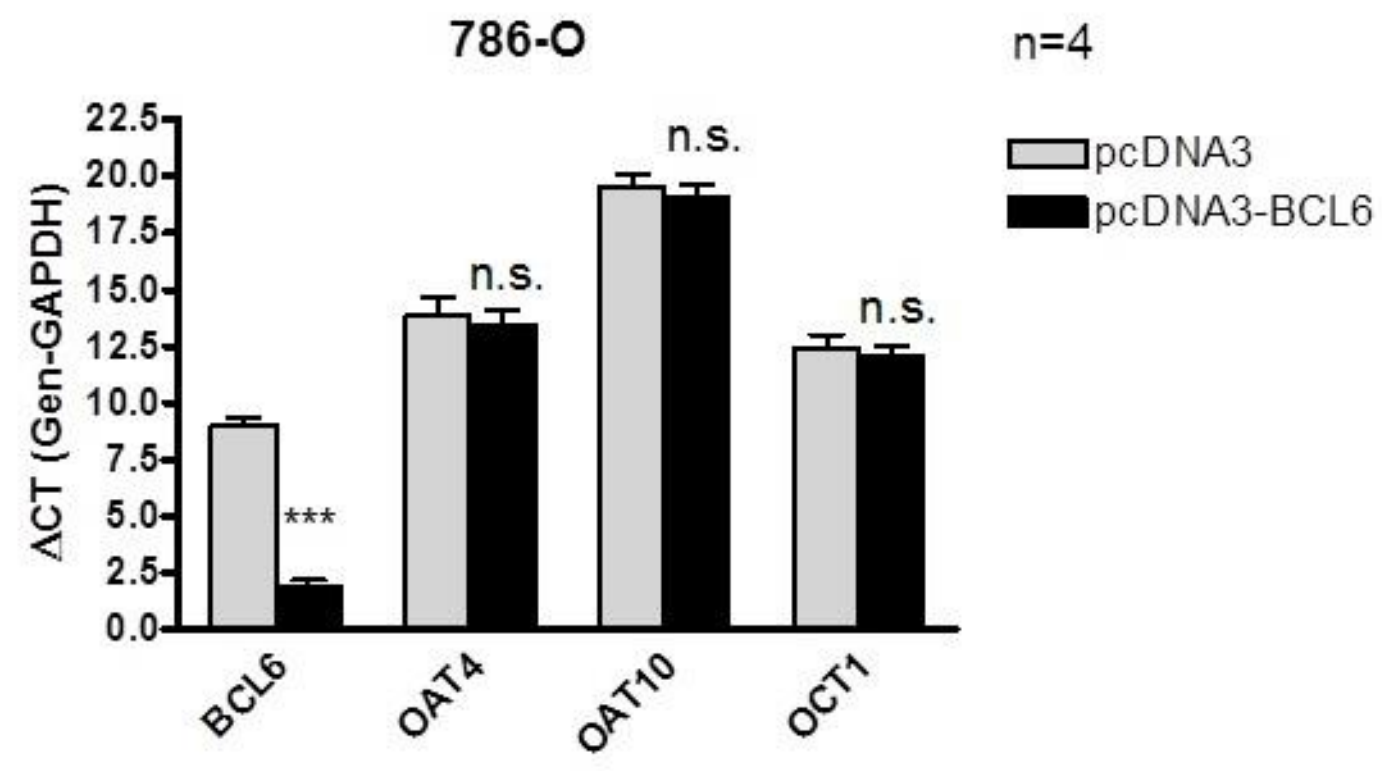

Abbildung 3.7: Beeinflussung der Expression von OATs und OCT1 durch BCL6-Überexpression in der Nierenkarzinomzelllinie 786-0.

Die Zellen wurden entweder mit dem Leervektor pcDNA3 (graue Balken) oder mit dem Expressionsplasmid pcDNA3-BCL6 (schwarze Balken) transfiziert. Die Daten wurden dargestellt als Mittelwert \pm S.E.M.; $n=4$. Statistische Analyse durch unpaired t-Test: ${ }^{* * *}=p<0,001,{ }^{*}=p<0,05$; n.s. $=$ nicht signifikant. $\Delta C T=$ Differenz zwischen dem untersuchten Gen und dem Haushaltsgen (GAPDH).

\subsubsection{OATs und OCT1 in ACHN}

Die Expressionsrate des BCL6-Gens wurde durch die Transfektion der Zellen mit dem BCL6Expressionsplasmid signifikant erhöht. Die Transporter OAT1, OAT3 und OAT4 waren in dieser Zelllinie nicht nachweisbar. OAT10 war in ACHN sehr niedrig exprimiert und es wurde kein Unterschied zwischen BCL6-transfizierten Zellen und Kontrollzellen nachgewiesen. Der Vergleich der $\triangle \mathrm{CT}$-Werte zeigte einen signifikanten Einfluss von BCL6 auf OCT1-mRNA. Die OCT1-mRNA wurde nach der Transfektion der Zellen mit BCL6 statistisch signifikant supprimiert. Die OCT1-mRNA wurde in BCL6-transfizierten Zellen durchschnittlich bei Zyklus 
35 detektiert. Da die Differenz zu den Leervektor-transfizierten Zellen relativ gering war, wurde der Transporter OCT1 (SLC22A1) nicht weiter untersucht.

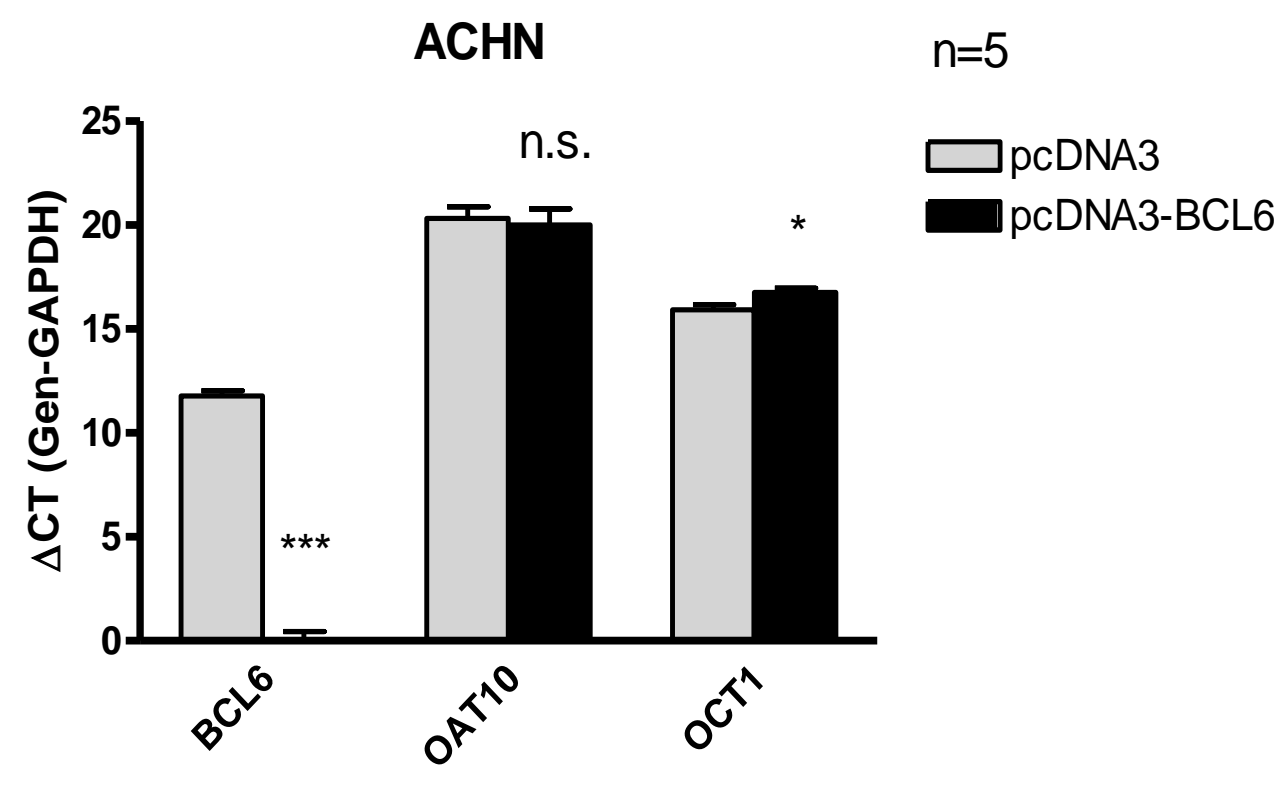

Abbildung 3.8: Beeinflussung der Expression von OAT10 und OCT1 durch BCL6-Überexpression in der Nierenkarzinomzelllinie ACHN.

Die Zellen wurden entweder mit dem Leervektor pcDNA3 (graue Balken) oder mit dem Expressionsplasmid pcDNA3-BCL6 (schwarze Balken) transfiziert. Die Daten wurden dargestellt als Mittelwert \pm S.E.M.; $n=5$. Statistische Analyse durch unpaired t-Test: ${ }^{* * *}=p<0,001,{ }^{*}=p<0,05$; n.s. $=$ nicht signifikant. $\Delta C T=$ Differenz zwischen dem untersuchten Gen und dem Haushaltsgen (GAPDH).

\subsubsection{OATs und OCT1 in LN78}

In den Zellen der Karzinomzelllinie LN78 wurde nachgewiesen, dass BCL6-mRNA in BCL6transfizierten Zellen im Vergleich zu Kontrollvektor-transfizierten Zellen signifikant erhöht wird (Abb. 3.9). Die mRNA von OAT1, OAT3 und OAT4 wurde in LN78-Zellen nicht exprimiert. Die Transporter OAT10 und OCT1 wurden in dieser Zelllinie nachgewiesen. Der Vergleich von pcDNA3- und BCL6-transfizierten Zellen zeigte in dieser Zelllinie für OAT10 und OCT1 keine signifikanten Unterschiede. 
LN78

$n=4$

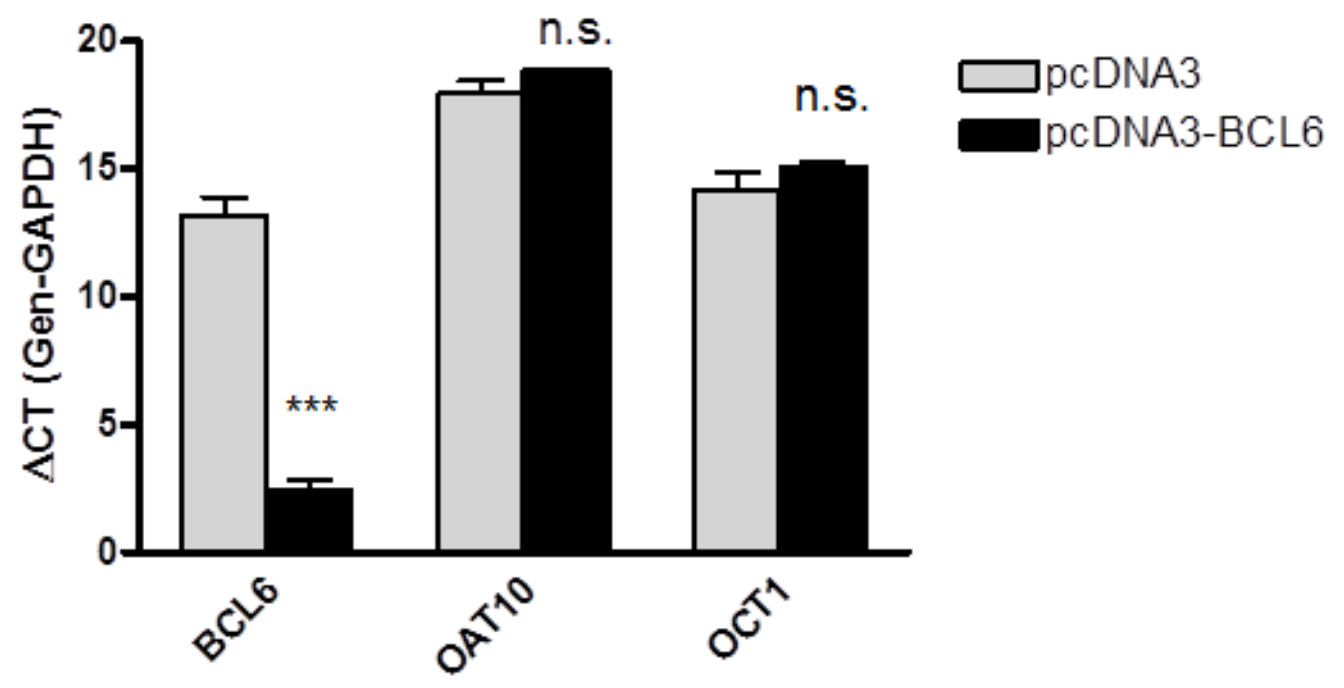

Abbildung 3.9: Beeinflussung der Expression von OATs und OCT1 durch BCL6-Überexpression in der Nierenkarzinomzelllinie LN78.

Die Zellen wurden entweder mit dem Leervektor pcDNA3 (graue Balken) oder mit dem Expressionsplasmid pcDNA3-BCL6 (schwarze Balken) transfiziert. Die Daten wurden dargestellt als Mittelwert \pm S.E.M.; $n=4$. Statistische Analyse durch unpaired $\mathrm{t}-$ Test: $^{* * *}=\mathrm{p}<0,001$; n.s. $=$ nicht signifikant. $\Delta \mathrm{CT}=$ Differenz zwischen dem untersuchten Gen und dem Haushaltsgen (GAPDH).

\subsubsection{OATs, OCTs, MRP2 und MDR1 in RCCNG1}

Der mRNA-Spiegel von BCL6 wurde durch die Transfektion mit dem Expressionsplasmid pcDNA3-BCL6 in der Zellinie RCCNG1 erhöht. RCCNG1-Zellen exprimieren nicht die Transportproteine OAT1, OAT3 und OCT3. Das Transportprotein OCT1 wurde nicht durch die BCL6-Überexpression beeinflusst. In dieser Zelllinie wurden zusätzlich zwei Mitglieder aus der Gen-Familie der ABC-Transporter, MRP2 und MDR1 untersucht. Die beiden ABCTransporter wurden in der Zelllinie RCCNG1 zwar exprimiert, aber durch die BCL6Transfektion nicht beeinflusst. Nach durchschnittlich 29,7 Zyklen wurde MRP2-mRNA detektiert. Bei dem Transportprotein MDR1 waren im Durchschnitt 37 PCR-Zyklen erforderlich, damit ein Fluoreszenzsignal detektiert werden konnte. MRP2 wurde in RCCNG1-Zellen demnach höher exprimiert als der Efflux-Transporter MDR1. 
RCCNG1

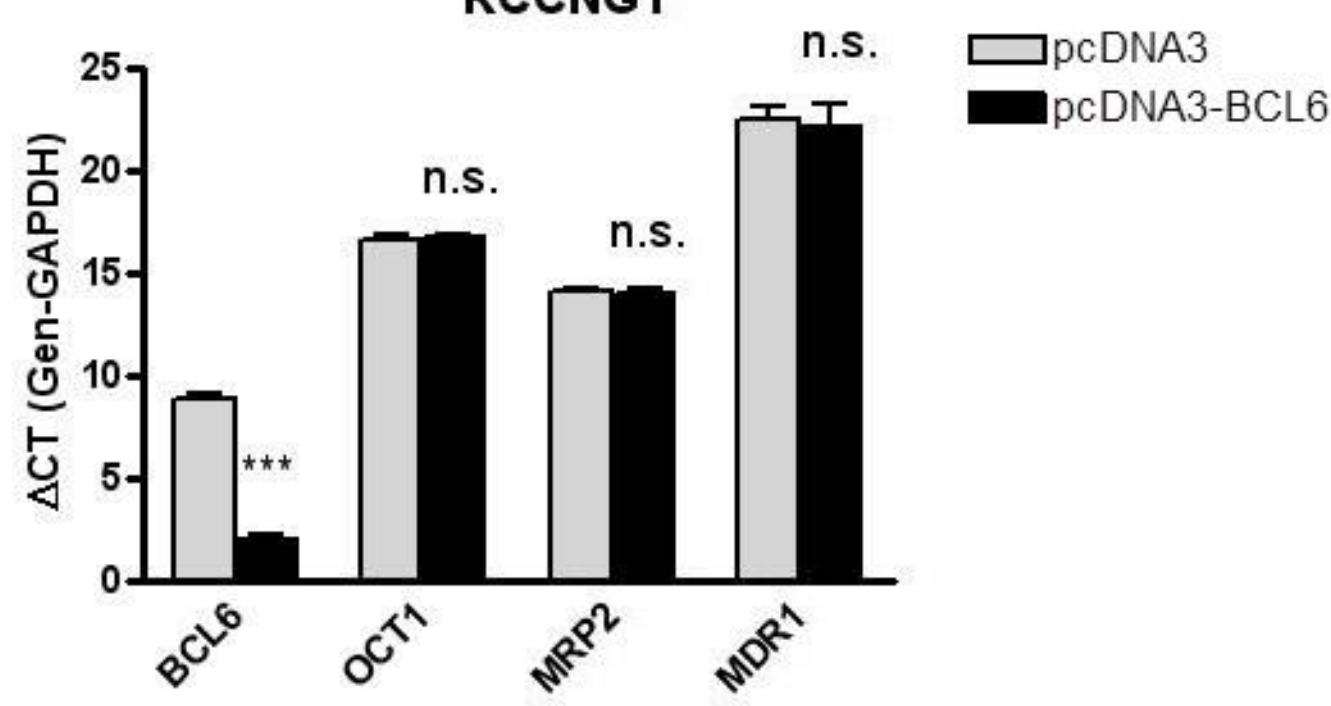

Abbildung 3.10: Beeinflussung der Expression von OATs, OATs, OCTs MRP2 und MDR1 durch BCL6Überexpression in der Nierenkarzinomzelllinie RCCNG1.

Die Zellen wurden entweder mit dem Leervektor pcDNA3 (graue Balken) oder mit dem Expressionsplasmid pcDNA3-BCL6 (schwarze Balken) transfiziert. Die Daten wurden dargestellt als Mittelwert \pm S.E.M.; $n=5$. Statistische Analyse durch unpaired $\mathrm{t}$-Test: ${ }^{* \star \star}=\mathrm{p}<0,001$; n.s. $=$ nicht signifikant. $\Delta \mathrm{CT}=$ Differenz zwischen dem untersuchten Gen und dem Haushaltsgen (GAPDH).

\subsubsection{Zusammenfassung der real-time PCR-Analyse}

In den Nierenkarzinomzelllinien 786-O, ACHN, LN78 und RCCNG1 wurde die Expression von OATs, OCTs und ABC-Transportern infolge der BCL6-Überexpression untersucht. Die Transfektion mit pcDNA3-BCL6 führte zu einer Überexpression des BCL6-Gens, aber zu keiner Änderung der untersuchten Transporter. Lediglich OCT1-mRNA wurde in der Zelllinie ACHN durch BCL6-Transfektion supprimiert. Die Suppression war statistisch signifikant, aber dennoch relativ gering. Aus diesem Grund wurde der Transporter OCT1 in der Zelllinie ACHN nicht weiter untersucht. Die folgende Tabelle (Tab. 3.1) gibt einen Überblick über die untersuchten Transporter. Außerdem wurden die Differenzen zwischen den pcDNA3- und pcDNA3-BCL6-transfizierten Zelllinien zusammengefasst. 


\section{Tabelle 3.1: Tabellarische Zusammenfassung der real-time PCR-Analyse}

Diese Tabelle stellt eine Zusammenfassung der Ergebnisse der real-time PCR dar. Es wird gezeigt, welche Transportproteine in den einzelnen Zelllinien exprimiert wurden und welche nicht. - = nicht detektiert; + = detektiert; n.u. = nicht untersucht; n.s. $=$ nicht signifikant; ${ }^{*}=p<0,05$.

\begin{tabular}{|c|c|c|c|c|c|c|c|c|c|}
\hline $\begin{array}{l}\text { Transporter } \\
\text { Zelllinie }\end{array}$ & OAT1 & OAT3 & OAT4 & OAT10 & OCT1 & ОСТ2 & OCT3 & MRP2 & MDR1 \\
\hline $786-0$ & - & - & $\begin{array}{r}+ \\
\text { n.s. }\end{array}$ & $\begin{array}{c}+ \\
\text { n.s. }\end{array}$ & $\begin{array}{r}+ \\
\text { n.s. }\end{array}$ & n.u. & n.u & n.u & n.u \\
\hline $\mathrm{ACHN}$ & - & - & - & $\begin{array}{r}+ \\
\text { n.s. }\end{array}$ & + & n.u. & n.u. & n.u & n.u \\
\hline LN78 & - & - & - & $\begin{array}{c}\mathbf{+} \\
\text { n.s. }\end{array}$ & $\begin{array}{r}+\boldsymbol{t} \\
\text { n.s. }\end{array}$ & n.u. & n.u. & n.u & n.u \\
\hline RCCNG1 & - & - & n.u & n.u & $\begin{array}{r}+ \\
\text { n.s. }\end{array}$ & - & - & $\begin{array}{r}+ \\
\text { n.s. }\end{array}$ & $\begin{array}{r}+ \\
\text { n.s. }\end{array}$ \\
\hline
\end{tabular}

\subsection{Untersuchung des BCL6-Proteins}

In diesem Experiment wurde zur Untersuchung des BCL6-Proteins die immunhistochemische Färbung für alle untersuchten Nierenkarzinomzelllinien angewendet, nachdem BCL6 mithilfe der real-time PCR nachgewiesen wurde. Dazu wurden die Zelllinien 786-O, ACHN, LN78 und RCCNG1 in unabhängigen Versuchen mit pcDNA3 oder pcDNA3BCL6 transfiziert. Die Immunfluoreszenz-Analyse von BCL6 zeigte in den Zellen der Nierenkarzinomzelllinie RCCNG1 BCL6-transfizierte Zellen (siehe Abb. 3.11). In dieser Zelllinie wurde BCL6 im Zellkern detektiert. Im Zytoplasma und in der Zellmembran konnte keine BCL6-Expression nachgewiesen werden. In RCCNG1-Zellen wurde BCL6 somit erfolgreich als Protein exprimiert. In den pcDNA3-transfizierten Kontrollzellen konnte keine endogene BCL6-Expression nachgewiesen werden (Abb. 3.11). Es wurden etwa 6,5\% RCCGN1-Zellen erfolgreich transfiziert. Bei der immunhistochemischen Analyse von BCL6 in den Zellinien 786-O, ACHN und LN78 wurden BCL6-positive Zellkerne nur in geringer Anzahl detektiert. Dabei waren unter $1 \%$ der Zellen nach der Transfektion mit pcDNA3BCL6 BCL6-positiv (Abb. 3.12). 


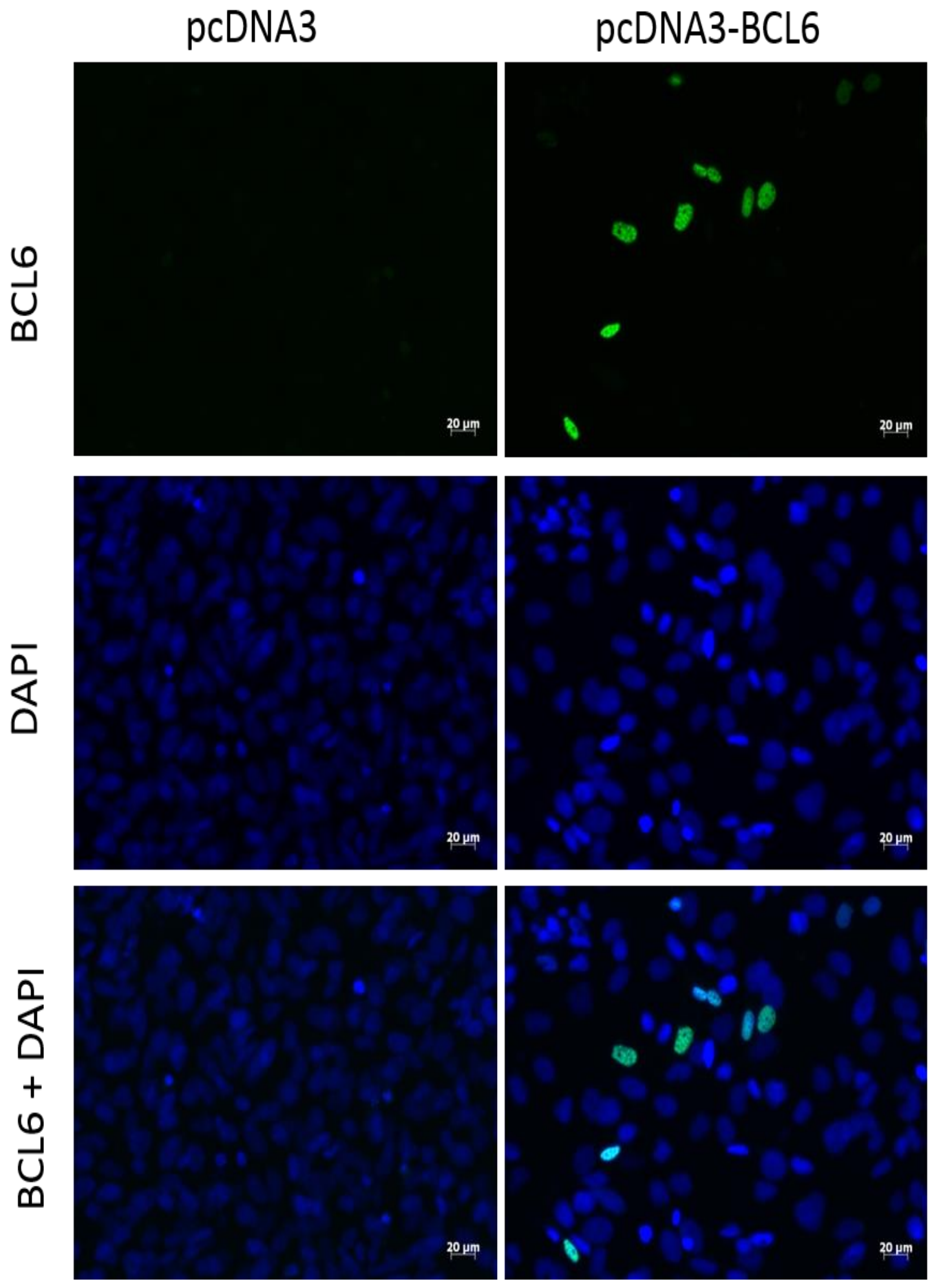

Abbildung 3.11: BCL6-Expression in RCCNG1-Zellen. Immunhistochemische Färbung.

Die Zellen der Zelllinie RCCNG1 wurden entweder mit dem Leervektor pcDNA3 oder mit dem Expressionsplasmid pcDNA3-BCL6 transfiziert und anschließend die Expression des BCL6-Proteins durch immunhistochemische Färbung analysiert. Als Primärantikörper wurde monoconal mouse anti BCL6 eingesetzt, als Sekundärantikörper Alexa Fluor 488 goat anti-mouse IgG. Zu sehen sind BCL6-transfizierte Zellkerne (grün) oder mit Fluoreszenzfarbstoff 4',6-Diamidino-2-Phenylindol (DAPI) gefärbte Zellkerne (blau); Auflösung $20 \mu \mathrm{m}$; Repräsentative Abbildung der Zellline RCCNG1. 
Das folgende Säulendiagramm (Abb. 3.12) gibt einen Überblick über die immunhistochemische Analyse der BCL6-Expression nach der BCL6-Transfektion in den Nierenkarzinomzelllinien 786-O, ACHN, LN78 und RCCNG1. Dabei wird deutlich, dass die BCL6-Transfektion nur die Protein-Expression von BCL6 in der Nierenkarzinomzelllinie RCCNG1 beeinflusste.

\section{Immunfluoreszenz}

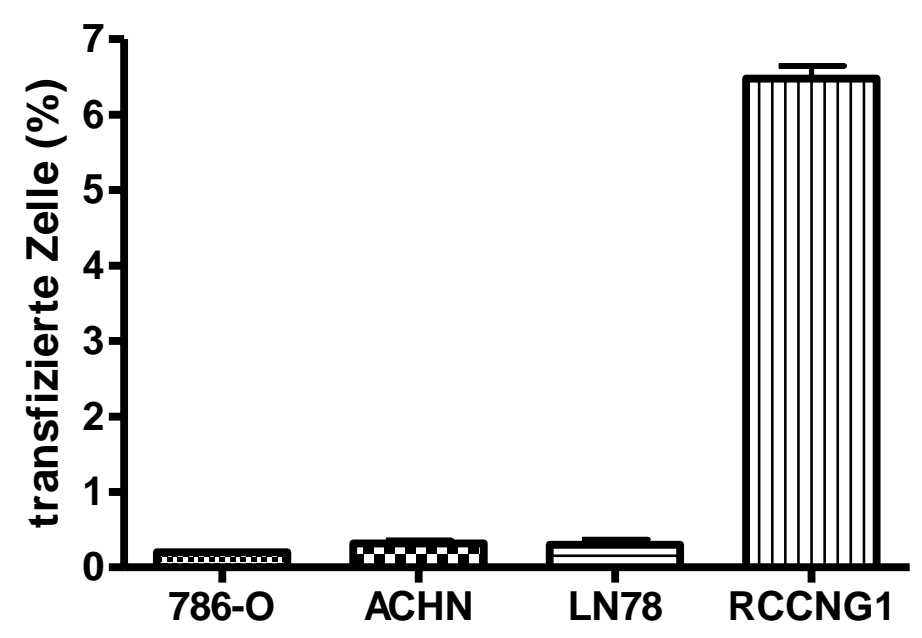

Abbildung 3.12: Immunfluoreszenz-Nachweis von BCL6 in 786-O, ACHN, LN78 und RCCNG1.

Überblick der immunhistochemischen Analyse der Zelllinien 786-O, ACHN, LN78 und RCCNG1. Die Zellen wurden entweder mit dem Leerfektor pcDNA3 oder mit dem Expressionsplasmid pcDNA3-BCL6 transfiziert und anschließend die Expression des BCL6-Proteins durch immunhistochemische Färbung analysiert. Als Primärantikörper wurde monoconal mouse anti BCL6 eingesetzt, als Sekundärantikörper diente Alexa Fluor 488 goat anti-mouse IgG. Die Balken zeigen jeweils an, wie viele Zellen der Zelllinien 786-O, ACHN, LN78 und RCCNG1 erfolgreich mit dem Expressionsplasmid pcDNA3-BCL6 transfiziert wurden.

\subsection{Der Effekt von BCL6 auf die Chemosensitivität der Nierenkarzinomzelllinie RCCNG1}

Im Folgenden sollte untersucht werden, ob die Chemosensitivität der Nierenkarzinomzelllinie RCCNG1 durch BCL6-Transfektion erhöht wird. Dazu wurde der Einfluss verschiedener Zytostatika auf den programmierten Zelltod der Zelllinie RCCNG1 untersucht. Die Apoptose wurde in BCL6- und in Leervektor-transfizierten Zellen untersucht. Für diese Experimente wurden drei Agenzien verschiedener Wirkstoffklassen in verschiedenen Konzentrationen getestet: der Antimetabolit 5-Fluorouracil (5-FU), der Topoisomerase-Hemmer Irinotecan und das Platinderivat Oxaliplatin. Das Experiment wurde viermal durchgeführt. Die Induktion der Apoptose aktiviert Caspasen. In den folgenden Experimenten wurde nach 16-stündiger Inkubation mit den jeweiligen Zytostatika die Enzymaktivität der Caspase-3 gemessen. Zudem wurde untersucht, ob mit ansteigenden Konzentrationen des zugefügten Zytostatikums Apoptose induziert wird und welchen Einfluss der Transkriptionsfaktor BCL6 
auf die Apoptose hat. Die Messungen wurden nach 30, 60 und 90 Minuten durchgeführt um zu analysieren, wann die Messung optimal ist.

\subsubsection{Der Einfluss von BCL6 auf die Chemosensitivität von RCCNG1-Zellen gegenüber 5-Fluorouracil}

Die pcDNA3- und pcDNA3-BCL6-transfizierten Zellen der Zelllinie RCCNG1 wurden 16 Stunden mit ansteigenden Konzentrationen 5-Fluorouracil ( $1 \mu \mathrm{M}, 10 \mu \mathrm{M}$ und $100 \mu \mathrm{M})$ oder mit dem organischen Lösungsmittel DMSO (Dimethylsulfoxid) inkubiert. Anschließend wurde die Caspaseaktivität gemessen. Es wurden bei keiner der eingesetzten Konzentrationen signifikante Unterschiede zwischen den BCL6-transfizierten Zellen und Kontrollzellen nachgewiesen (Abb. 3.13). Nach der Inkubation der Zellen mit $10 \mu \mathrm{M}$ 5-FU wurde bei BCL6transfizierten Zellen eine höhere Caspase-3-Aktivität gemessen als bei den Leervektortransfizierten Zellen. Dieser Unterschied ist jedoch nicht signifikant $(p>0,05)$. Bei den Konzentrationen $1 \mu \mathrm{M}$ und $100 \mu \mathrm{M}$ ist die Apoptoserate bei pcDNA3-transfizierten Zellen geringfügig höher.

\section{RCCNG1}

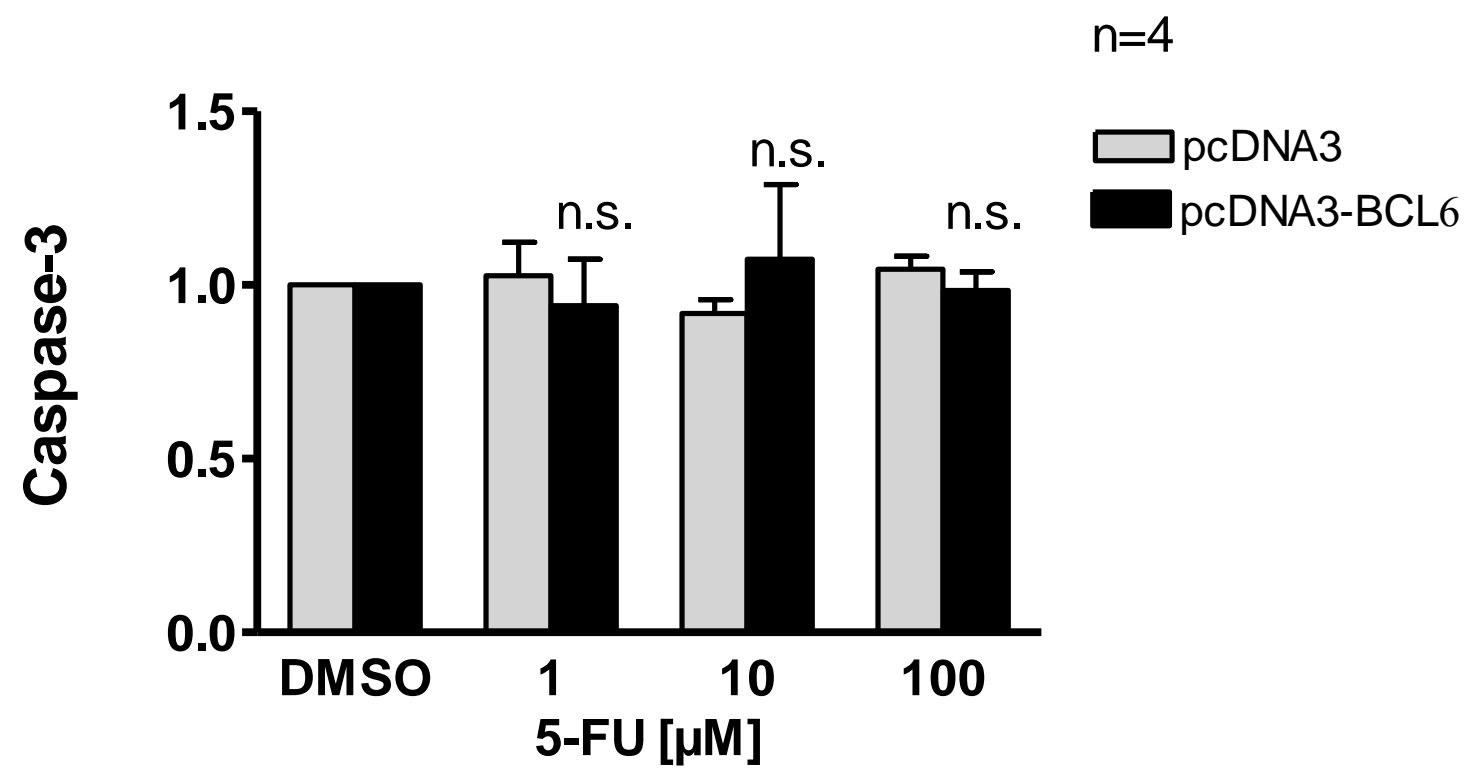

Abbildung 3.13: Caspaseaktivität nach Inkubation mit 5-FU.

Die RCCNG1-Zellen wurden nach der Transfektion mit dem Leervektor pcDNA3 (graue Balken) oder mit dem Expressionsvektor pcDNA3-BCL6 (schwarze Balken) entweder mit DMSO (Dimethylsulfoxid) als Kontrolle oder mit dem Zytostatikum 5-Fluorouracil in den Konzentrationen $1 \mu \mathrm{M}, 10 \mu \mathrm{M}$ sowie $100 \mu \mathrm{M}$ exponiert und 16 Stunden inkubiert. Die Caspaseaktivität wurde mithilfe des EnzChek® Caspase-3-Assay Kit \# 2 gemessen. Die Daten wurden dargestellt als Mittelwert \pm S.E.M.; $n=4$; n.s. = nicht signifikant. Statistische Analyse durch den zweiseitigen ungepaarten t-Test: Vergleich zwischen pcDNA3- und pcDNA3-BCL6-transfizierten Zellen. Der 
Vergleich der verschiedenen Konzentrationen mit der Lösungsmittelkontrolle (Dimethylsulfoxid oder Wasser) erfolgte durch one-way ANOVA mit dem Dunnett's multiple comparison-Test.

\subsubsection{Der Einfluss von BCL6 auf die Chemosensitivität von RCCNG1-Zellen gegenüber Irinotecan}

In diesem Versuch wurden die Zellen 16 Stunden mit dem Zytostatikum Irinotecan inkubiert und die Caspaseaktivität untersucht. Auch Irinotecan induziert keine Apoptose von BCL6und Leervektor-transfizierten Zellen (Abb. 3.14). Bei einer Konzentration von $10 \mu \mathrm{M}$ wurde die höchste Caspase-3-Aktivität sowohl bei BCL6-transfizierten Zellen als auch bei den Kontrollzellen nachgewiesen. Bei den Leervektor-transfizierten Zellen konnte man bei der Konzentration von $10 \mu \mathrm{M}$ Irinotecan eine höhere Caspaseaktivität nachweisen als bei BCL6transfizierten RCCNG1-Zellen. Der Transkriptionsfaktor BCL6 führte zu keiner signifikant veränderten Chemosensitivität der RCCNG1-Zellen gegenüber Irinotecan.

\section{RCCNG1}

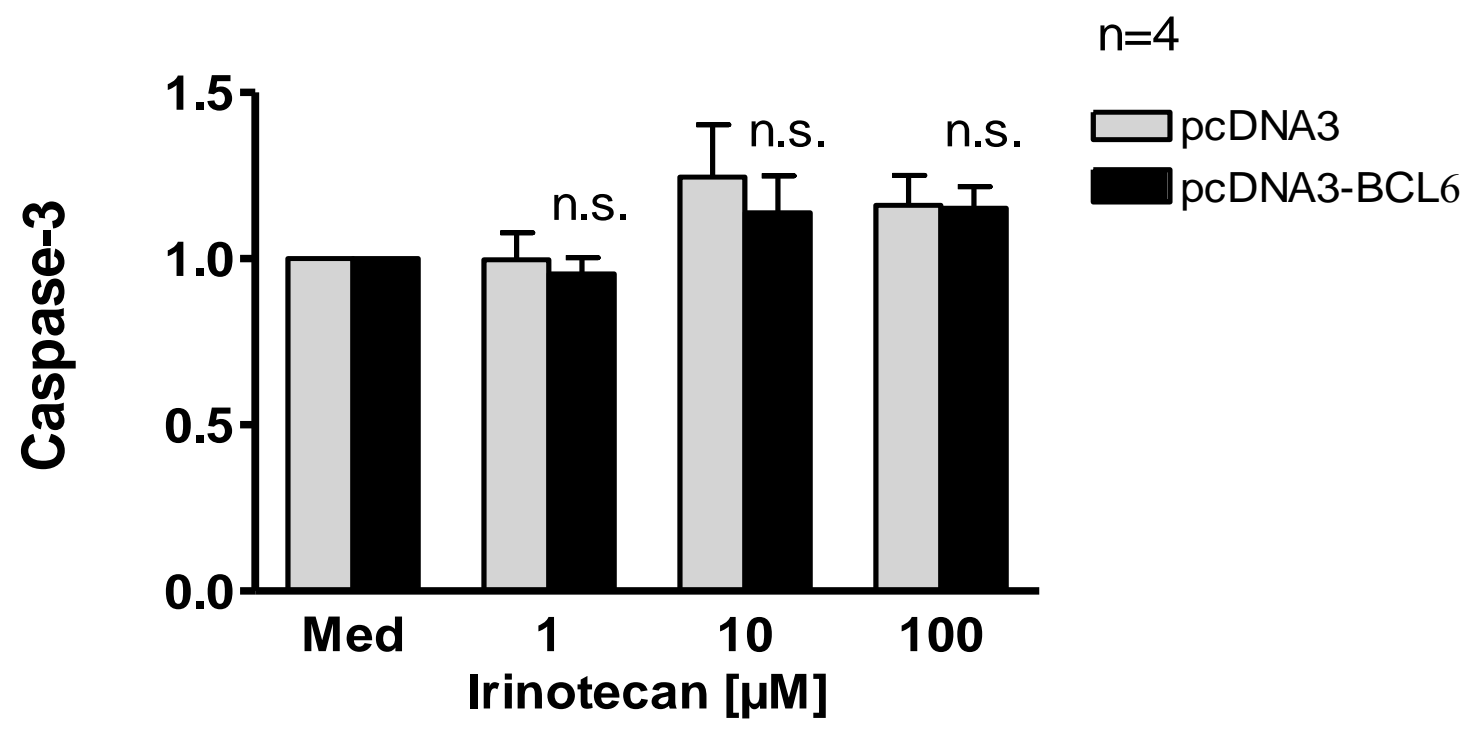

Abbildung 3.14: Caspaseaktivität nach Inkubation mit Irinotecan.

Die RCCNG1-Zellen wurden nach der Transfektion mit dem Leervektor pcDNA3 (graue Balken) oder mit dem Expressionsvektor pcDNA3-BCL6 (schwarze Balken) entweder mit Medium (Med) als Kontrolle oder mit dem Zytostatikum Irinotecan in den Konzentrationen $1 \mu \mathrm{M}, 10 \mu \mathrm{M}$ sowie $100 \mu \mathrm{M}$ exponiert und 16 Stunden inkubiert. Die Caspaseaktivität wurde mithilfe des EnzChek® Caspase-3-Assay Kit \# 2 gemessen. Die Daten wurden dargestellt als Mittelwert \pm S.E.M.; $n=4 ;$ n.s. = nicht signifikant. Statistische Analyse durch den zweiseitigen ungepaarten t-Test: Vergleich zwischen pcDNA3- und pcDNA3-BCL6-transfizierten Zellen. Der Vergleich der verschiedenen Konzentrationen mit der Lösungsmittelkontrolle (Dimethylsulfoxid oder Wasser) erfolgte durch one-way ANOVA mit dem Dunnett's multiple comparison-Test. 


\subsubsection{Der Einfluss von BCL6 auf die Chemosensitivität von RCCNG1-Zellen gegenüber Oxaliplatin}

Das Zytostatikum Oxaliplatin wurde in diesem Experiment neben den Konzentrationen $1 \mu \mathrm{M}$, $10 \mu \mathrm{M}$ und $100 \mu \mathrm{M}$ zusätzlich mit der Konzentration $150 \mu \mathrm{M}$ getestet. Dabei wurde bei der höchsten eingesetzten Konzentration die höchste Caspaseaktivität bei sowohl BCL6transfizierten als auch pcDNA3-transfizierten Zellen nachgewiesen. Die Caspaseaktivität war bei den Konzentrationen $10 \mu \mathrm{M}, 100 \mu \mathrm{M}$ und $150 \mu \mathrm{M}$ bei den Leervektor-transfizierten Zellen höher als bei den Zellen, die mit dem Expressionsplasmid BCL6 transfiziert wurden. Mit aufsteigender Oxaliplatin-Konzentration ist bei den Leervektor-transfizierten Zellen ein Trend zur höheren Apoptoserate zu erkennen, wenngleich mithilfe des Dunnett-Tests kein signifikanter Unterschied nachgewiesen werden konnte.

\section{RCCNG1}

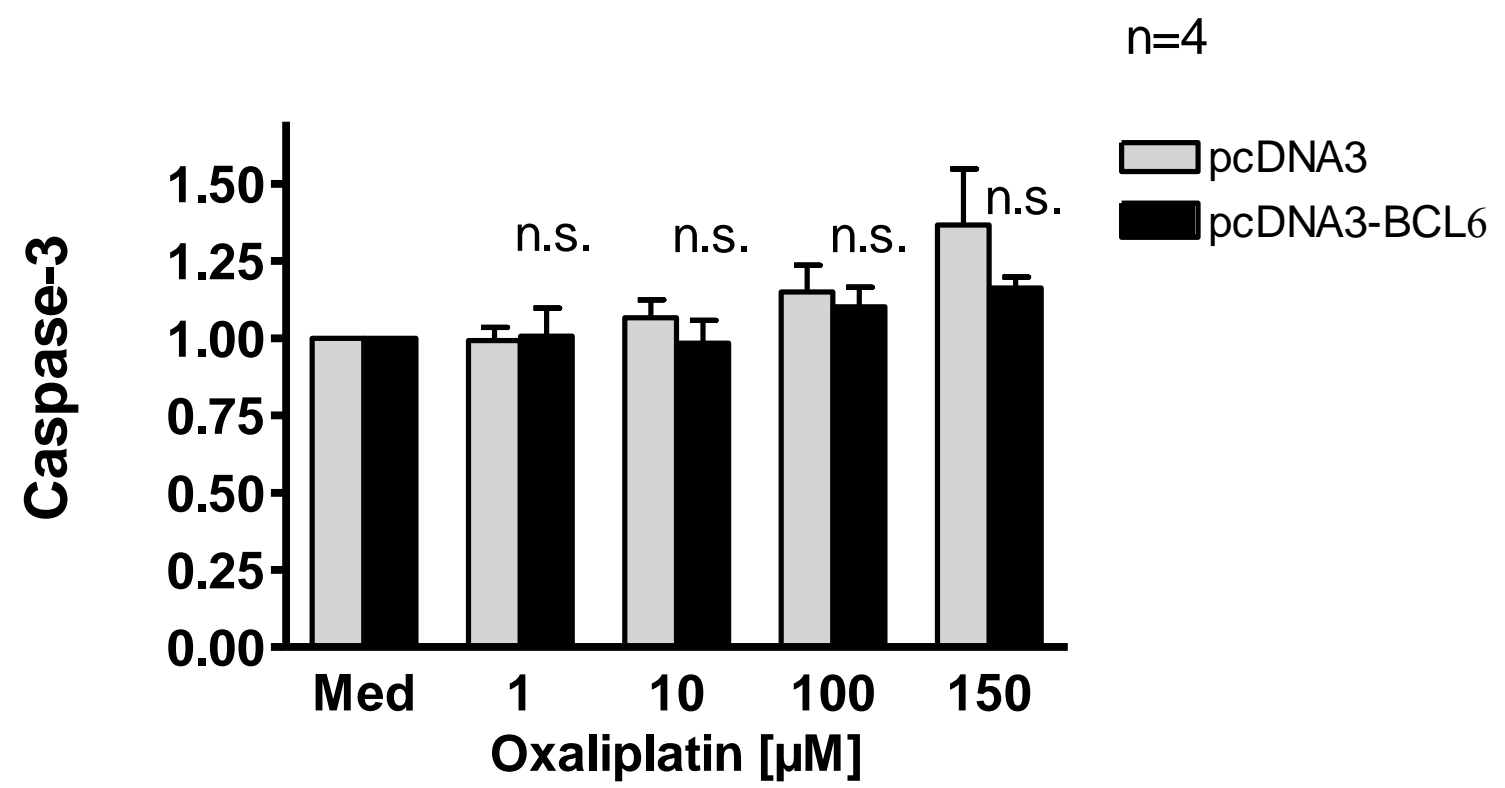

Abbildung 3.15: Caspaseaktivität nach Inkubation mit Oxaliplatin.

Die RCCNG1-Zellen wurden nach der Transfektion mit dem Leervektor pcDNA3 (graue Balken) oder mit dem Expressionsvektor pcDNA3-BCL6 (schwarze Balken) entweder mit Medium (Med) als Kontrolle oder mit dem Zytostatikum Oxaliplatin in den Konzentrationen $1 \mu \mathrm{M}, 10 \mu \mathrm{M}, 100 \mu \mathrm{M}$ sowie $150 \mu \mathrm{M}$ exponiert und 16 Stunden inkubiert. Die Caspaseaktivität wurde mithilfe des EnzChek® Caspase-3-Assay Kit \# 2 gemessen. Die Daten wurden dargestellt als Mittelwert \pm S.E.M.; $n=4 ; n . s .=$ nicht signifikant. Statistische Analyse durch den zweiseitigen ungepaarten t-Test: Vergleich zwischen pcDNA3- und pcDNA3-BCL6-transfizierten Zellen. Der Vergleich der verschiedenen Konzentrationen mit der Lösungsmittelkontrolle (Dimethylsulfoxid oder Wasser) erfolgte durch one-way ANOVA mit dem Dunnett's multiple comparison-Test. 


\section{Diskussion}

Das Nierenzellkarzinom nimmt mit weltweit schätzungsweise 271.000 Neuerkrankungen und 116.000 Todesfällen im Jahr 2008 stark an Inzidenz und Mortalität zu (Xu et al. 2014). In den meisten Fällen ist die Chemotherapie als Behandlungsmethode erfolglos (Martel und Lara 2003). Die Chemoresistenz beruht neben anderen Ursachen auf dem beschleunigten Zytostatika-Efflux aus den Karzinomzellen (Sharom 2008, Zhou 2008). Für den Efflux der Zytostatika sind unter anderem die ABC-Transporter MDR1 und MRP2 verantwortlich, welche in Tumorgeweben im Gegensatz zu gesunden Geweben erhöht exprimiert werden (Soini et al. 2001). Bisher ist nicht geklärt, ob die Chemoresistenz auch aus der herabgesetzten Aktivität der Influx-Transporter resultieren könnte (Huang 2007). Es wäre möglich, dass der durch SLC-Transporter vermittelte Influx bestimmter Zytostatika in die Nierenkarzinomzellen einen entscheidenden Punkt für die erfolgreiche Chemotherapie darstellen könnte. Es ist unklar, wie viele Zytostatika-Moleküle tatsächlich in die Karzinomzelle gelangen und welche Faktoren den Influx beeinflussen. Es stellt sich die Frage, ob man die Expression der SLC-Transportproteine in Nierenkarzinomzellen exogen beeinflussen und auf diese Weise eine Überexpression der Aufnahmetransporter induzieren kann. In der Vergangenheit wurden bereits einige Transkriptionsfaktoren (z.B. HNF1 und BCL6) nachgewiesen, welche die Expression der Transportproteine regulieren (Miles et al. 2005, Kikuchi et al. 2006, Saji et al. 2008, Jin et al. 2012, Wegner et al. 2012, Wegner et al. 2014). Erste Resultate über den Einfluss von B-cell CLL/lymphoma 6 (BCL6) auf Nierenzellen wurden von Wegner et al. veröffentlicht (Wegner et al. 2012). Die Arbeitsgruppe erbrachte später den Nachweis, dass BCL6 indirekt durch die Erhöhung des Transkriptionsfaktors hepatocyte nuclear factor 1 alpha (HNF1a) die Expression des OAT1Promotors erhöht (Wegner et al. 2014). Unter Berücksichtigung dieser Erkenntnisse stellt sich die Frage, ob BCL6 auch einen Einfluss auf weitere OATs, OCTs und ABC-Transporter in Nierenkarzinomzellen ausüben könnte. In diesem Zusammenhang ist anzunehmen, dass Nierenkarzinomzellen durch eine erhöhte BCL6-induzierte Expression der SLC-Transporter sensitiver gegenüber Zytostatika werden. Zur Überprüfung dieser Hypothese wurden Experimente auf molekularbiologischer, zellbiologischer, immunhistochemischer und pharmakologischer Ebene durchgeführt.

\subsection{Nachweis des BCL6-Gens in den Nierenkarzinomzelllinien}

Die verwendeten Nierenkarzinomzelllinien 786-O, ACHN, LN78 und RCCNG1 wurden entweder mit dem Leervektor pcDNA3 oder mit dem Expressionsplasmid pcDNA3-BCL6 transfiziert. Die präsentierten Daten der PCR-Analyse zeigen, dass die Nierenkarzinomzelllinien 786-O, ACHN, LN78 und RCCNG1 BCL6-mRNA auch endogen exprimieren (siehe Abb. 3.2 - 3.5). Dieses Ergebnis unterstützt die von Wagner et al. 
beschriebene Annahme, dass BCL6 in Tumorzellen erhöht exprimiert sein könnte (Wagner et al. 2011). Die Arbeitsgruppe begründet diese Annahme damit, dass BCL6-mRNA ein Ziel für miR-127 (mikroRNA-127) darstellt (Saito et al. 2006). Dabei handelt es sich um eine kurze, nicht-kodierende RNA, welche durch sequenzspezifische Interaktion mit ihrer ZielmRNA deren Translation reprimieren kann. Da Karzinomzellen weniger miR-127 exprimieren als gesunde Zellen, könnte dies eine gesteigerte BCL6-Expression zur Folge haben (Wagner et al. 2011). Um herauszufinden, ob BCL6 in Nierenkarzinomzellen tatsächlich höher exprimiert ist als in gesunden Nierenzellen, müssten zum Vergleich Untersuchungen an gesunden Nierenzellen durchgeführt werden.

\subsection{Beeinflussung der Expression renaler Transportproteine in 786-0, ACHN, LN78 und RCCNG1 durch BCL6}

Da die Reaktion der Karzinomzellen auf die Chemotherapie von der intrazellulären Zytostatikakonzentration abhängig ist (Huang 2007), war das eigentliche Ziel der Untersuchungen herauszufinden, ob sich die Expression der Influx-Transporter der SLC22Familie infolge der BCL6-Überexpression in den Nierenkarzinomzellinien 786-O, ACHN, LN78 und RCCNG1 erhöhen lässt. Neben der Superfamilie der SLC-Membranproteine beeinflusst auch die Superfamilie der ABC-Transporter die Pharmakokinetik von Medikamenten (Huang 2007). Die MRPs sind ATP-getriebene Transportsysteme, die vornehmlich Zytostatika und andere Substrate aus der Zelle exportieren und somit deren Akkumulation in den Zellen verhindern (siehe Kapitel 1.4). Die Tatsache, dass Nierenkarzinomzellen Multidrug-Resistance-Transporter höher exprimieren als gesunde Zellen, unterstützt die Annahme, dass Nierenkarzinomzellen als chemoresistent anzusehen sind (Soini et al. 2001). Aus diesem Grund wurden im Rahmen dieser Arbeit zusätzlich zu den SLC22-Transportern auch zwei Efflux-Transporter der ABC-Familie in der Nierenkarzinomzelllinie RCCNG1 untersucht. Die folgende Tabelle gibt einen Überblick über die für den Zytostatika-Transport potentiellen SLC-Transporter. Im Anschluss werden die Ergebnisse der real-time PCR-Analyse diskutiert. 
Tabelle 4.1: Mögliche Zytostatika-Transporter der SLC- und ABC-Familie

Transporter der SLC- und ABC-Familie, welche in dieser Arbeit untersucht wurden und mit Zytostatika interagieren. $+=$ Interaktion, $\mathrm{u}=$ unbekannt (Toffoli et al. 2003, Yonezawa et al. 2006, Zhang et al. 2006, Kusuhara und Sugiyama 2009, Shnitsar et al. 2009).

\begin{tabular}{|l|l|l|l|}
\hline Transporter & 5-Flourouracil & Irinotecan & Oxaliplatin \\
\hline OAT1 & $\mathrm{u}$ & $\mathrm{u}$ & $\mathrm{u}$ \\
\hline OAT3 & $\mathrm{u}$ & $\mathrm{u}$ & $\mathrm{u}$ \\
\hline OAT4 & $\mathrm{u}$ & $\mathrm{u}$ & $\mathrm{u}$ \\
\hline OAT10 & $\mathrm{u}$ & $\mathrm{u}$ & $\mathrm{u}$ \\
\hline OCT1 & $\mathrm{u}$ & + & + \\
\hline OCT2 & $\mathrm{u}$ & $\mathrm{u}$ & + \\
\hline OCT3 & $\mathrm{u}$ & + & + \\
\hline MRP2 & $\mathrm{u}$ & + & $\mathrm{u}$ \\
\hline MDR1 & $\mathrm{u}$ & + & $\mathrm{u}$ \\
\hline
\end{tabular}

\subsubsection{Beeinflussung der Expression der Influx-Transporter in 7860-O, ACHN, LN78 und RCCNG1 durch BCL6}

In den Experimenten wurde die Expression von OAT1, OAT3, OAT4 und OAT10 in pcDNA3BCL6-und in Leervektor pcDNA3-transfizierten Nierenkarzinomzelllinien 786-O, ACHN, LN78 und RCCNG1 untersucht. Die Transporter OAT1 und OAT3 konnten in keiner der untersuchten Nierenkarzinomzelllinien nachgewiesen werden. Diese beiden OrganischeAnionen-Transporter sind für die Aufnahme einer Vielzahl von negativ geladenen Arzneimitteln vom Blut in die proximalen Nierentubuluszellen verantwortlich (Burckhardt und Burckhardt 2003). Es ist bekannt, dass OAT1 und OAT3 das Zytostatikum Methotrexat transportieren (Takeda et al. 2002, Burckhardt und Burckhardt 2011, Burckhardt 2012). Aus diesem Grund wurde angenommen, dass OAT1 und OAT3 auch für den Influx anderer Zytostatika verantwortlich sein könnten. Da Gupta et al. die OAT3-Expression sowohl in Leukämiezellen als auch bei Patienten mit chronischer lymphatischer Leukämie nachgewiesen haben (Gupta et al. 2011a), war eine OAT3-Expression auch in anderen Karzinomzellen denkbar. Die Tatsache, dass DNA-Methylierung die Promotoraktivität des OAT1 und des OAT3 unterdrückt (Kikuchi et al. 2006, Jin et al. 2012), könnte eine mögliche Ursache dafür sein, dass die beiden Transporter in den Karzinomzellinien nicht nachgewiesen werden konnten. Interessanterweise konnten Hagos et al. erstmalig in RCCNG1-Zellen die Expression von OAT1 durch Transfektion mit dem Transkriptionsfaktor hepatocyte nuclear factor 4 alpha (HNF4 $\alpha$ ) nachweisen und im Gegensatz zu Leervektortransfizierten Zellen erhöhen (Hagos et al. 2014). Allerdings war der mRNA-Level von OAT1 in dieser Studie sehr niedrig und konnte erst nach etwa 36 PCR-Zyklen detektiert werden. Dennoch stützt das Ergebnis von Hagos et al. (2014) die Annahme, dass OAT1-mRNA 
durch Transkriptionsfaktoren moduliert werden kann. Die möglichen Gründe, warum BCL6 keinen Effekt auf die OAT1-Expression in RCCNG1-Zellen ausübt, werden weiter unten diskutiert (siehe Kapitel 4.3).

Derzeit liegen keine Berichte über die spezifische Expression des OAT4 in Karzinomzellen vor (Gupta et al. 2011a). Nur in der Nierenkarzinomzelllinie 786-O wurde die mRNA des asymmetrischen Antiporters OAT4 nachgewisen (siehe Tab. 3.1). Die Karzinomzelllinien ACHN und LN78 haben dieses Transportprotein nicht exprimiert. Dieses Ergebnis zeigt, dass sich die exprimierten Transporter zwischen Nierenkarzinomzelllinien verschiedener Patienten unterscheiden.

Des Weiteren wurde OAT10 in den Zellinien 786-O, ACHN und LN78 untersucht und detektiert. Allerdings zeigen die präsentierten Daten, dass sich die Expression von OAT10 in BCL6-transfizierten Zellen im Vergleich zu Leervektor-transfizierten Zellen nicht signifikant änderte. Dieses Ergebnis lässt vermuten, dass der Transkriptionsfaktor BCL6 keinen Einfluss auf die Expression von OAT10 in Nierenkarzinomzelllinien hat. In diesem Zusammenhang ist hinzuzufügen, dass bis zum heutigen Zeitpunkt hierzu noch keine Experimente durchgeführt wurden. Es bleibt unklar, ob die Genexpression vom Typ des Nierenzellkarzinoms abhängig sein könnte. Sültmann et al. konnten beispielsweise nachweisen, dass die Genexpression des MDR1 nur im papillären Typ des Nierenzellkarzinoms, nicht aber im Klarzellkarzinom erhöht wird (Sültmann et al. 2005).

Da OCTs eine breite Substratspezifität aufweisen, könnten auch diese Transportproteine eine Rolle in der Chemosensitivität der Karzinomzellen spielen (Koepsell et al. 2007). In der Vergangenheit konnte in den Untersuchungen von Hayer-Zillgen et al. die Expression von OCTs in verschiedenen humanen Karzinomzelllinien nachgewiesen werden (Hayer-Zillgen et al. 2002). In den vorliegenden Experimenten wurde daher die Expression von OCT1, OCT2 und OCT3 untersucht. Die mRNA der drei Transportproteine konnten bisher gemeinsam nur in der Kolonkarzinomzelllinie Caco-2 nachgewiesen werden (Bleasby et al. 2000, HayerZillgen et al. 2002). Untersuchungen von Heise et al. ergaben, dass OCT1 und OCT3 in Zellen des hepatozellulären Karzinoms herunterreguliert werden (Heise et al. 2012). Es ist bekannt, dass OCT1 Zytostatika transportieren kann (Zhang et al. 2006, Gupta et al. 2011a). OCT1 konnte in den vorliegenden Versuchen in allen vier untersuchten Nierenkarzinomzelllinien nachgewiesen werden. In der Zelllinie ACHN wurde die Expression von OCT1 entgegen der Erwartungen durch Transfektion mit BCL6 supprimiert. Dieses Ergebnis zeigt, dass BCL6 einen negativen Einfluss auf die OCT1-Expression in der Zelllinie $\mathrm{ACHN}$ hat. Die Suppression war statistisch signifikant, aber relativ gering. Deshalb wurde das Transportprotein OCT1 in der Zelllinie ACHN nicht weiter untersucht. In einer Studie von 
Hagos et al. konnte OCT1-mRNA in der Zelllinie RCCNG1 durch Überexpression des Transkriptionsfaktors HNF4a signifikant erhöht werden (Hagos et al. 2014). OCT2 vermittelt die Aufnahme des Zytostatikums Cisplatin in die proximalen Nierentubuli und ist somit für die Nephrotoxizität dieses Arzneimittels verantwortlich (Ciarimboli et al. 2005). Aus diesem Grund wurde OCT2 in der Karzinomzellinie RCCNG1 untersucht. Eine erhoffte Expression dieses Transporters blieb jedoch aus. Hagos et al. konnten OCT2 in RCCNG1-Zellen nach 40 PCR-Zyklen ebenfalls nicht nachweisen (Hagos et al. 2014). Eine veränderte Expression des OCT3 konnte bisher in verschiedenen Karzinomen festgestellt werden (Shnitsar et al. 2009, Heise et al. 2012). OCT3 wurde nur in RCCNG1-Zellen untersucht und nach 40 PCRZyklen nicht detektiert. Shnitsar et al. konnten OCT3 in RCCNG1-Zellen nach 30 PCRZyklen nicht nachweisen (Shnitsar et al. 2009). Da Shnitsar et al. jedoch erstmals die Expression und auch Funktionalität des OCT3 in einer Nierenkarzinomzelllinie (Zelllinie A498) nachweisen konnten (Shnitsar et al. 2009), haben wir zu Beginn der Untersuchungen auch eine Expression des OCT3 in RCCNG1-Zellen vermutet. Spätere Untersuchungen zeigten die Expression des OCT3 in 786-O, ACHN und LN78, wobei unterschiedliche Expressionslevel des Transporters ausgemacht werden konnten (Hagos et al. 2014, Marada 2014).

Die Karzinomzellen verfügen über verschiedene epigenetische und genetische Mechanismen, mit denen sie ihre Genexpression verändern können (Shen et al. 2012). Unter Berücksichtigung dieser Erkenntnis kann die Hypothese aufgestellt werden, dass Nierenkarzinomzellen aufgrund veränderter Genexpression die Expression von InfluxTransportern als eine Art Selbstschutzmechanismus herunterregulieren. Ein mögliches Beispiel für einen solchen Mechanismus ist die hoch- und herunterregulierte Expression von mikroRNA (miRNA) in Karzinomzellen (Masereeuw und Russel 2012, Shen et al. 2012). Die miRNAs sind in der Lage, die Genexpression durch Repression der Translation der ZielmRNA oder durch RNA-Abbau zu beeinflussen (lorio et al. 2005). Die Beeinflussung der Genexpression durch miRNAs kann sowohl durch Herunterregulierung als auch durch Hochregulierung der Translation der mRNA erfolgen (Valinezhad Orang et al. 2014). In der Literatur wird berichtet, dass miRNAs die Expression von Transportproteinen beeinflussen können (Pullen et al. 2011, Masereeuw und Russel 2012). In einer Doktorarbeit der Abteilung konnte kein Einfluss von untersuchten miRNAs auf die Expression des InfluxTransporters OCT3 in Nierenkarzinomzellen gezeigt werden (Marada 2014). Ein weiteres Beispiel für eine veränderte Genexpression von Transportproteinen in den Karzinomzellen stellen DNA-Methylierungen und Histon-Modifizierungen dar (Masereeuw und Russel 2012). Diese epigenetischen Mechanismen haben einen Einfluss auf die Expression einiger SLCTransporter in Kolonkarzinomzelllinien (Ikehata et al. 2012). Marada erbrachte hingegen den 
Nachweis, dass sowohl Deacetylierung der Histone als auch DNA-Methylierung nicht für eine verminderte OCT3-Expression in ACHN-Zellen verantwortlich sind (Marada 2014). Im Gegensatz dazu wurden die Promotoraktivitäten von OAT1 und OAT3 durch DNAMethylierung unterdrückt (Kikuchi et al. 2006, Jin et al. 2012).

\subsubsection{Beeinflussung der Expression der Efflux-Transporter MDR1 und MRP2 in RCCNG1 durch BCL6}

Im Gegensatz zu bereits publizierten Daten (Shnitsar et al. 2009), in denen MDR1 in der Karzinomzellinie RCCNG1 mithilfe der Standard-PCR nicht detektiert werden konnte, wurde MDR1 in dieser Arbeit mithilfe der real-time PCR-Analyse in RCCNG1 nachgewiesen. Eine mögliche Erklärung dafür ist, dass die Arbeitsgruppe Shnitsar et al. nur bis PCR-Zyklus 30 amplifiziert hat, die Experimente der vorliegenden Arbeit hingegen bis Zyklus 40 durchgeführt wurden. Das ermittelte Expressionsprofil der real-time PCR zeigt, dass die Expression der MDR1-mRNA relativ niedrig ist. Diese Ergebnisse führen zu der Annahme, dass die Ursache für die Chemoresistenz der Nierenkarzinomzelllinie RCCNG1 nicht in der Expression des ABC-Transporters MDR1 zu suchen ist. MRP2 ist klinisch sehr wichtig, da es die Pharmakokinetik vieler Medikamente moduliert und die Expression sowie die Aktivität dieses Transportproteins durch bestimmte Medikamente und Krankheitsstadien verändert werden kann (Gerk und Vore 2002). Die veränderte Funktion des MRP2-Transporters kann die Clearance vieler klinisch wichtiger Arzneimittel verändern. Dazu zählen u.a. Zytostatika (Irinotecan, Methotrexat und Vinblastin) und verschiedene Antibiotika (Gerk und Vore 2002). In den vorliegenden Experimenten wurde MRP2 in RCCNG1-Zellen höher exprimiert als der ABC-Transporter MDR1 und die Transportproteine OCT1 und OCT2. Dieses Ergebnis unterstützt die Annahme, dass MRP2 zur Chemoresistenz der Nierenkarzinomzelllinie RCCNG1 beitragen könnte. Der Transkriptionsfaktor BCL6 hat in RCCNG1 Zellen jedoch keinen signifikanten Einfluss auf die Expression von MRP2. Für die erhöhte Expression des Transporters MRP2 in RCCNG1-Zellen können jedoch verschiedene andere Faktoren verantwortlich sein. $\mathrm{Zu}$ diesen Faktoren könnten die veränderte Aktivität anderer Transkriptionsfaktoren in Karzinomzellen, Gen-Polymorphismen, Genumlagerungen und Hypo- oder Hypermethylierungen der Promotoren zählen (Kim et al. 2006, Masereeuw und Russel 2012).

Weiterhin ist zu erwähnen, dass auch experimentelle Ursachen zu den erzielten Ergebnissen geführt haben könnten. Da die RNA in den vorliegenden Experimenten 48 Stunden nach der BCL6-Transfektion isoliert wurde, könnte es möglich sein, dass die RNA nach dieser Inkubationszeit bereits abgebaut war. Experimente, die eine Zeitreihenanalyse mit einschließen, müssten sich anschließen, um diese Vermutung endgültig zu bestätigen. 


\subsection{Nachweis des BCL6-Proteins in den Nierenkarzinomzelllinien}

Die Auswertung der Daten zeigte, dass eine hohe BCL6-Expression auf mRNA-Ebene vorliegt. Dennoch war unklar, warum BCL6 keinen Einfluss auf die Aktivierung der untersuchten Transportproteine hat. Aufgrund dessen wurde im Rahmen dieser Arbeit eine Antikörperfärbung in der Arbeitsgruppe etabliert, mit der BCL6 in den untersuchten Nierenkarzinomzelllinien als Protein nachgewiesen werden sollte. Die immunhistochemische Färbung diente dem Nachweis, ob die Translation, die Synthese des BCL6-Proteins in den Nierenkarzinomzelllinien, erfolgreich war. Dazu wurden die Zelllinien 786-O, ACHN, LN78 und RCCNG1 entweder mit pcDNA3 oder pcDNA3-BCL6 transfiziert und anschließend die Expression des BCL6-Proteins durch immunhistochemische Färbung analysiert. Eine Expression des BCL6-Proteins konnte mithilfe der Immunfluoreszenz-Analyse nur für die Zellinie RCCNG1 nachgewiesen werden. Dadurch wird bestätigt, dass mit BCL6-transfizierte RCCNG1-Zellen den Transkriptionsfaktor BCL6 im Zellkern exprimieren. Obwohl das Plasmid pcDNA3-BCL6 exogen zugefügt wurde, wird das Gen in den Zelllinien 786-O, ACHN und LN78 nicht translatiert. Die Tatsache, dass das BCL6-Protein nur in der Nierenkarzinomzellinie RCCNG1 geringfügig nachweisbar ist, lässt vermuten, dass der Prozess der Translation in den anderen untersuchten Nierenkarzinomzelllinien gestört sein könnte. Da Karzinomzellen generell ihre Genexpression verändern können (Shen et al. 2012), wäre es zum einen vorstellbar, dass die Nierenkarzinomzellinien 786-O, ACHN und LN78 über einen Mechanismus verfügen, mit dem sie RNA schneller abbauen können, sodass eine Synthese von Proteinen anhand von mRNA in den Ribosomen nicht mehr möglich ist. Zum anderen wäre möglich, dass die Nierenkarzinomzelllinien das Gen trotz Transfektion mit dem Expressionsplasmid BCL6 nicht translatieren. Das GenExpressionsmuster der Zelllinie RCCNG1 ähnelt proximalen Tubuluszellen mehr als die anderen untersuchten Nierenkarzinomzellinien (Hagos et al. 2014). Diese Tatsache könnte eine mögliche Ursache dafür sein, dass nur die Zelllinie RCCNG1 BCL6 als Protein exprimiert.

\subsection{Einfluss des BCL6-Proteins auf die Chemosensitivität von RCCNG1- Zellen}

Da das BCL6-Protein nur in der Karzinomzellinie RCCNG1 nachgewiesen werden konnte, wurden die Zelllinien 786-O, ACHN und LN78 in dieser Phase der Experimente vernachlässigt.

So wurde in den vorliegenden Experimenten untersucht, ob sich die Chemosensitivität der Nierenkarzinomzelllinie RCCNG1 gegenüber ausgewählten Zytostatika (siehe Tab. 4.1) 
durch BCL6-Überexpression erhöhen lässt. Die RCCNG1-Zellen wurden dafür nach der Transfektion mit dem Leervektor pcDNA3 oder mit dem Expressionsvektor pcDNA3-BCL6 16 Stunden mit unterschiedlichen Konzentrationen eines der drei ausgewählten Zytostatika behandelt. Im Anschluss wurde die Caspase-3-Aktivität gemessen.

Zunächst wurde der Effekt von BCL6 auf die Chemosensitivität der RCCNG1-Zellen gegenüber 5-Fluorouracil (5-FU) getestet. Der Pyrimidin-Antimetabolit 5-FU wurde 1957 entwickelt (Heidelberger et al. 1957). 5-FU wird intrazellulär durch verschiedene Phosyphorylierungsschritte zu seinen aktiven Metaboliten 5-Fluorodeoxyurinmonophospat (5-FdUMP), 5-Fluorodeoxyuridintriphosphat (5-FdUTP), oder Fluorouridintriphosphat (5FUTP) umgewandelt (Schilsky 1998). Die aktiven Metaboliten 5-FdUTP bzw. 5-FUTP können aufgrund ihrer Strukturähnlichkeit mit den Pyrimidinbasen Cytosin, Thymidin und Uracil in die DNA bzw. RNA eingebaut werden (Schilsky 1998). Auf diese Weise hemmt 5FU die DNA- und RNA-Synthese und wirkt somit zytotoxisch (Schilsky 1998). Zudem hemmt 5-FdUMP das Enzym Thymidylat-Synthase und inhibiert dadurch ebenfalls die DNASynthese (Schilsky 1998). Seit einigen Jahren wird 5-FU in Form von kontinuierlichen intravenösen Infusionen als Kombinationstherapie mit anderen Therapien zur Behandlung des Nierenzellkarzinoms eingesetzt (Gebrosky et al. 1997). Die Kombinationstherapie besteht meist aus der Kombination aus Interleukin-2, Interferon- $\alpha$ und 5-FU (Dempke 2006). 5-FU ist ein nachgewiesenes Substrat des OAT2 (Kobayashi et al. 2005). Die präsentierten Daten zeigen, dass sowohl Leervektor-transfizierte als auch BCL6-transfizierte RCCNG1Zellen nach 16-stündiger Inkubation mit 5-FU nicht mit Apoptose reagieren. Im Gegensatz dazu wurde in der Arbeit von Hagos et al. die Caspase-3-Aktivität in HNF4a-transfizierten RCCNG1-Zellen nach 16-stündiger Inkubation mit sowohl $1 \mu \mathrm{M}$ als auch $10 \mu \mathrm{M}$ 5-FU signifikant erhöht (Hagos et al. 2014). Der wahrscheinlichste Grund für den Unterschied zwischen dem erzielten Ergebnis und den von Hagos et al. publizierten Daten ist die Verwendung unterschiedlicher Transkriptionsfaktoren.

Es bleibt außerdem zu klären, ob weitere, in dieser Arbeit nicht untersuchte Transportproteine zur Chemosensitivität der RCCNG1-Zellen gegenüber 5-FU beitragen. Die Arbeitsgruppe Pratt et al. konnte in Experimenten an mit MRP5 tranfizierten HEK293-Zellen (Zellen aus humaner emybronaler Niere) die MRP5-vermittelte Chemoresistenz gegenüber 5-FU detektieren (Pratt et al. 2005). Als mögliche weitere Transporter kommen die equilibrativen Nukleosid-Transporter 1-3 (equilibrative nucleoside transporter, ENT1, ENT2, ENT3) der SLC29-Familie für einen gesteigerten Efflux oder verminderten Influx von 5-FU in Frage. Shnitsar konnte die Transporter ENT1-3 in RCCNG1-Zellen nachweisen und hat eine Affinität von ENT1 und ENT2 für 5-FU beschrieben (Shnitsar 2008). Hagos et al. konnten die mRNA von ENT1, ENT2 und ENT3 nach 28-29 PCR-Zyklen in RCCNG1-Zellen nachweisen (Hagos et al. 2014). Die Arbeitsgruppe hat zudem den konzentrativen Nukleosid-Transporter 
3 (concentrative nucleoside transporter 3, CNT3), ein Membrantransporter der SCL28Familie, als Kandidaten für die 5-FU-induzierte Chemosensitivität in RCCNG1-Zellen beschrieben (Hagos et al. 2014). CNT3 steigert die Akkumulation von 5-Fluordeoxyuridin (5FUDR), dem Metabolit von 5-FU (Hagos et al. 2014).

Als weiteres Zytostatikum wurde für die Experimente der Topoisomerase-I-Inhibitor Irinotecan ausgewählt. Irinotecan wird in Kombination mit 5-FU und Folinsäure (FOLFIRI) zur Behandlung des kolorektalen Karzinoms eingesetzt (Lee et al. 2005). Irinotecan ist ein halbsynthetisches Camptothecinderivat. Das Alkaloid Camptothecin wird aus der Pflanze Camptotheca acuminata isoliert. Irinotecan ist ein Prodrug, welches in der Leber durch Carboxylesterasen in die aktive Form SN38 metabolisiert wird (Rivory et al. 1996, Wu et al. 2002, Ramesh et al. 2010). Die Bindung von SN38 an die DNA-Topoisomerase-I bewirkt eine Enzymhemmung. Die Topoisomerase-I ist für die DNA-Replikation, die RNA-Translation und den Zellzyklus essentiell (Rothenberg 1997). Durch Glucuronidierung wird SN38 in der Leber zu SN38-Glucuronid inaktiviert. Auch nach 16-stündiger Inkubation mit Irinotecan wurde keine Apoptose in den RCCNG1-Zellen induziert. BCL6 kann die Chemosensitivität der RCCNG1-Zellen gegenüber Irinotecan nicht beeinflussen. Die Tatsache, dass die Zellen der Karzinomzelllinie RCCNG1 auf Irinotecan nicht mit Apoptose reagieren, könnte zu einem darauf zurückzuführen sein, dass die intrazelluläre Wirkkonzentration von Irinotecan nicht ausreichend ist, um zytotoxisch wirksam zu sein. Shnitsar et al. zeigten, dass der Aufnahmetransporter OCT3 die Aufnahme von Irinotecan vermittelt (Shnitsar et al. 2009), doch dieser Transporter wurde in RCCNG1-Zellen nicht exprimiert. Zudem wurde die Interaktion von OCT1 mit Irinotecan beschrieben (Gupta et al. 2011b). OCT1 wird in der untersuchten Zelllinie RCCNG1 exprimiert und könnte somit u.a. für die Aufnahme von Irinotecan in RCCNG1-Zellen verantwortlich sein. Dennoch stellt sich die Frage, warum sich RCCNG1-Zellen trotz wahrscheinlicher intrazellulärer Anreicherung des Arzneimittels den zelltoxischen Einflüssen des Zytostatikums entziehen und durch hohe Zytostatikagaben nicht in ihrem autonomen Zellwachstum gehindert werden. In diesem Prozess spielen wahrscheinlich die Efflux-Transporter eine Rolle. Irinotecan gilt als Substrat für den EffluxTransporter MDR1 (Toffoli et al. 2003, Kusuhara und Sugiyama 2009). Damit kann festgehalten werden, dass die intrazelluläre Konzentration des aktiven Metaboliten SN38 von drei Faktoren abhängig ist: von der Carboxylesteraseaktivität, der UDPGlucuronosyltransferaseaktivität und von der Aktivität des Efflux-Transporters MDR1. Da die Expression der MDR1-mRNA in den präsentierten Daten als niedrig nachgewiesen werden konnte, ist der Transporter MDR1 nicht als wahrscheinliche Ursache für einen vermehrten Efflux von SN38 zu werten. Der Transport von Irinotecan durch den MRP2 konnte bisher invitro nachgewiesen werden (Chen und Tiwari 2011). Diese Erkenntnis lässt die Annahme zu, 
dass RCCNG1-Zellen auf das Zytostatikum Irinotecan nicht mit Apoptose reagieren, da das Medikament durch den in der Zelllinie RCCNG1 exprimierten Transporter MRP2 vermehrt aus den Karzinomzellen heraustransportiert wird. Genauso könnten auch andere Transporter am Efflux des Medikaments beteiligt sein. Mögliche Kandidaten wären die Multidrug-andToxin-Extrusion-Transporter 1 und 2 (MATE1 und MATE2) der SLC47-Familie, die beide in der luminalen Membran der proximalen Tubuluszellen exprimiert werden (Otsuka et al. 2005, Masuda et al. 2006). MATE-Transportproteine sezernieren sowohl endogene als auch exogene Substanzen. Es wurde bereits gezeigt, dass das Zytostatikum Oxaliplatin von MATE1 und MATE2-K transportiert wird (Yonezawa et al. 2006). MATE1 transportiert zudem die Zytostatika Topotecan (Tanihara et al. 2007) und Cisplatin (Yonezawa et al. 2006). Obwohl MATE1 insbesondere als Efflux-Transportprotein beschrieben wird (Otsuka et al. 2005, Tanihara et al. 2007), konnte MATE1 in einigen Studien als Aufnahmetransporter nachgewiesen werden (Chen et al. 2007, Watanabe et al. 2010, Minematsu und Giacomini 2011). Grottker et al. konnten in Experimenten eine Interaktion von MATE1 mit Irinotecan nachweisen, lieferten jedoch keine endgültige Aussage, ob MATE1 den Transport von Irinotecan vermittelt (Grottker et al. 2011).

Als drittes Zytostatikum wurde in den durchgeführten Experimenten die antineoplastische Substanz Oxaliplatin ausgewählt. Oxaliplatin ist ein Platinderivat der dritten Generation, das insbesondere zur Behandlung des kolorektalen Karzinoms, häufig in Kombination mit 5-FU und Folinsäure (FOLFOX-Therapieschema), eingesetzt wird (De Gramont et al. 2000, Van Cutsem et al. 2010). Im Gegensatz zum Zytostatikum Cisplatin induziert Oxaliplatin keine Nephrotoxizität und weist somit ein günstigeres Toxizitätsprofil auf (Raymond et al. 2002). Die antitumorale Wirkung von Oxaliplatin soll auf der Bildung von Di-Platin-DNA-Addukten und deren Interaktion mit der DNA beruhen, wodurch die DNA-Replikation und -Transkription gestört werden (Rothenberg 2000). Die durch die Platinierung entstandenen DNA-Schäden induzieren der programierten Zelltod (Todd und Lippard 2009). Oxaliplatin ist ein bekanntes Substrat des OCT1 und des OCT2 (Yonezawa et al. 2006, Zhang et al. 2006). Die präsentieren Daten zeigen, dass OCT1 in der Nierenkarzinomzelllinie RCCNG1 exprimiert ist und damit zur Aufnahme von Oxaliplatin in die RCCNG1-Zellen beitragen könnte. Da die Zytotoxizität und Akkumulation von Oxaliplatin insbesondere durch die Expression von OCT1 (Zhang et al. 2006) und OCT2 (Yonezawa et al. 2006, Zhang et al. 2006) erhöht wird, war eine Oxaliplatin-induzierte Apoptose der RCCNG1-Zellen zu erwarten. Die erzielten Ergebnisse zeigen allerdings zum einen, dass Oxaliplatin keine Apoptose in RCCNG1-Zellen auslöst, und zum anderen, dass BCL6 keinen positiven Effekt auf die Chemosensitivität der RCCNG1-Zellen gegenüber Oxaliplatin bewirkt. Oxaliplatin ist ein Substrat für die Transporter OCT1, OCT2, OCT3, MATE1 und MATE2-K (Yonezawa et al. 2006, Zhang et al. 2006, Lovejoy et al. 2008, Burger et al. 2010). Des Weiteren sind die in dieser Arbeit nicht 
betrachteten Zwitterionen-/Kationentransporter OCTN1 und OCTN2 (OrganischeKationen/Carnitin-Transporter) der SLC22-Familie an der Aufnahme von Oxaliplatin beteiligt (Jong et al. 2011). Es wäre möglich, dass RCCNG1-Zellen verschiedene, in dieser Arbeit nicht untersuchte Efflux-Transporter überexprimieren könnten, welche Oxaliplatin vermehrt aus den Zellen heraustransportieren. Dazu zählen die Transporter MATE1 und MATE2-K, die bereits mit dem Oxaliplatin-Efflux aus proximalen Tubuluszellen in Zusammenhang gebracht wurden (Yonezawa et al. 2006, Yokoo et al. 2007). Eine verringerte intrazelluläre Oxaliplatin-Konzentration wurde auch durch eine erhöhte Expression der Transporter MRP1 und MRP4 in Ovarialkarzinomzellen beschrieben (Beretta et al. 2010). Shnitsar et al. konnten zeigen, dass MRP4 in 786-O, ACHN, LN78 und RCCNG1 exprimiert ist (Shnitsar et al. 2009). Aus diesem Grund müssten für eine vollständige Erklärung der Chemoresistenz von RCCNG1-Zellen auch die Transportproteine MATE1, MATE2-K, MRP1 und MRP4 berücksichtigt und untersucht werden. Des Weiteren könnten andere Transkriptionsfaktoren einen Einfluss auf die Oxaliplatin-induzierte Apoptose in RCCNG1-Zellen haben. Hagos et al. haben den Effekt des Transkriptionsfaktors HNF4 $\alpha$ auf die Chemosensitivität von RCCNG1Zellen gegenüber Oxaliplatin untersucht und konnten beobachten, dass die Caspaseaktivität in HNF4a-transfizierten RCCNG1-Zellen im Gegensatz zu Kontrollzellen signifikant erhöht wird (Hagos et al. 2014).

\subsection{Einfluss weiterer Faktoren auf die Nierenkarzinomtherapie}

Es bleibt zu diskutieren, welche anderen Zielstrukturen und Strategien zur gezielten Karzinomtherapie eingesetzt werden könnten. Einen möglichen Ansatzpunkt stellen miRNAs dar. In der Vergangenheit wurden verschiedene miRNAs beobachtet, welche die Chemosensitivität von Cisplatin-resistenten Zelllinien durch Regulation der Apoptose erhöhen können (Shen et al. 2012). Diese Tatsache lässt die Annahme zu, dass miRNAs möglicherweise auch die Chemosensitivität der Zelllinie RCCNG1 beeinflussen könnten. Untersuchungen von $\mathrm{Xu}$ et al. an Nierenkarzinomzellinien ergaben, dass mi182-5p in Nierenkarzinomzellinien herunterreguliert ist und eine induzierte Überexpression dieser miRNA die Proliferation der Karzinomzellen supprimiert ( $\mathrm{Xu}$ et al. 2014). Einen weiteren möglichen Ansatzpunkt stellt der Wnt-Signalweg dar, welcher die Zellproliferation und die Zelldifferenzierung reguliert (MacDonald et al. 2009). Die Fehlregulation des Wnt-Signalwegs wird mit der Tumorentstehung, -progression und -aggresivität verschiedener Organe in Verbindung gebracht (Waaler et al. 2011). Die Signalmoleküle der Wnt-Signalwege sind Wnt-Proteine. Eine zentrale Rolle dieser Signalkaskade nimmt das intrazelluläre Protein $\beta$ Catenin ein (Clevers 2006). Durch Bindung des Wnt-Liganden an seinen Rezeptor reichert sich $\beta$-Catenin im Zellkern und im Zytoplasma an und kann im Zellkern an Transkriptionsfaktoren binden, wodurch die Transkription bestimmter Wnt-Zielgene aktiviert 
wird (Clevers 2006, MacDonald et al. 2009). Untersuchungen von Hsu et al. ergaben, dass der Wnt10A-Ligand in Nierenkarzinomzelllinien hochreguliert ist (Hsu et al. 2012). Die Überexpression von Wnt10A und $\beta$-Catenin im NZK hat eine erhöhte Zellproliferation, Zellinvasion, Zellmigration und eine erhöhte Chemoresistenz zur Folge (Hsu et al. 2012). Hagos et al. konnten eine hohe Expression von $\beta$-Catenin im Zytoplasma, in der Zellmembran und im Zellkern von RCCNG1-Zellen nachweisen (Hagos et al. 2014). In Anlehnung an diese Erkenntnis wäre es denkbar, dass eine Herunterregulierung des $\beta$ Catenins und/oder des Wnt10A-Liganden zu einer erhöhten Chemosensitivität der RCCNG1Zellen führen könnte. Pal et al. konnten erstmals nachweisen, dass spezifische TelomerBindungsfaktoren und deren Inhibition durch siRNA (small interfering RNA) als Angriffspunkte zur Therapie des Nierenkarzinoms dienen könnten (Pal et al. 2015). Telomere sind spezifische DNA-Sequenzen am Ende der Chromosomen, die keine kodierenden Information besitzen und für den Schutz der Chromosomen unverzichtbar sind (Armanios und Blackburn 2012). Die Telomere selbst werden durch spezifische Bindungsproteine geschützt, die dem sogenannten Shelterin-Komplex angehören (De Lange 2005). Zwei dieser Bindungsproteine sind die von $\mathrm{Pal}$ et al. untersuchten telomeric repeat binding factors TRF1 und TRF2 (De Lange 2005). In ihren Untersuchungen konnte in Nierenkarzinomzellinien eine erhöhte Expression von TRF1 und TRF2 sowohl auf mRNAals auch auf Proteinebene im Vergleich zum gesunden Nierenparenchym beobachtet werden (Pal et al. 2015). Somit stellten Pal et al. die Hypothese auf, dass diese Hochregulation ein genereller Mechanismus von Nierenkarzinomzellen sein könnte. Weiterhin wurde festgestellt, dass der Einsatz von siRNA die Expression von TRF1 und TRF2 in der Nierenkarzinomzellllinie A498 unterdrückt. Diese experimentelle Stillegung der Bindungsproteine hatte Auswirkungen auf den Zellzyklus („Zellzyklus-Arrest“), verminderte die Zellproliferation und induzierte 96 Stunden nach der Behandlung mit siRNA eine erhöhte Apoptoserate in der Nierenkarzinomzelllinie im Vergleich sowohl zu unbehandelten Zellen als auch zu Kontrollzellen in-vitro (Pal et al. 2015). Die präsentierten Ergebnisse dieser Publikation führen zu der Annahme, dass die siRNA von Telomer-Bindungsproteinen effektive Substanzen zur Behandlung des Nierenzellkarzinoms darstellen könnten, möglicherweise auch im Hinblick auf die Chemosensitivität. 


\section{Zusammenfassung}

Das Nierenzellkarzinom stellt mit $86 \%$ den häufigsten bösartigen Tumor der Nieren dar. Viele Patienten mit Nierenzellkarzinom weisen bereits bei der Diagnosestellung Metastasen auf. Die Therapiemöglichkeiten zur Behandlung des Nierenzellkarzinoms sind bis heute limitiert. Aus diesem Grund ist die Etablierung neuer Behandlungsmöglichkeiten unumgänglich. Ich habe mit dieser Studie versucht, einen Beitrag zur Verbesserung der Chemotherapie des Nierenzellkarzinoms zu leisten, indem ich mögliche Beeinflussungsmöglichkeiten der Expression von Zytostatika-Transportern des Nephrons zur zielgerichteten Chemotherapie untersucht habe. Eine klare Aussage, die von dieser Arbeit abgeleitet werden kann, ist, dass der untersuchte Transkriptionsfaktor BCL6 keinen signifikanten Einfluss auf die Expression von Transportproteinen in den Nierenkarzinomzelllinien 786-O, ACHN, LN78 und RCCNG1 ausübt und auch daraus resultierend die Chemosensitivität dieser Nierenkarzinomzelllinien nicht erhöht. Entgegen den Erwartungen konnte in der Nierenkarzinomzelllinie ACHN ein geringfügiger negativer Einfluss von BCL6 auf die OCT1-Expression nachgewiesen werden. Die immunhistochemische Analyse lieferte den Nachweis, dass die Nierenkarzinomzelllinien 786-O, ACHN und LN78 den Transkriptionsfaktor BCL6 nicht als Protein exprimieren. Die Behandlung der RCCNG1-Zellen mit den Zytostatika 5-FU, Irinotecan und Oxaliplatin führte nicht zur gewünschten Apoptoserate und konnte durch BCL6 nicht beeinflusst werden. Da die Expression der untersuchten Transportproteine zwischen den Nierenkarzinomzelllinien verschiedener Patienten variiert, sollte die Chemotherapie der Patienten individuell auf deren Transporter-Expression abgestimmt werden. 


\section{Anhang}

\subsection{Abkürzungsverzeichnis}

\begin{tabular}{|c|c|}
\hline Abb. & Abbildung \\
\hline ABC & ATP-binding cassette \\
\hline ACE & angiotensin converting enzyme \\
\hline$\alpha$ & Alpha \\
\hline ATP & Adenosintriphosphat \\
\hline ANOVA & analysis of variance \\
\hline BCL6 & B-cell lymphoma 6 \\
\hline$\beta$ & Beta \\
\hline$\beta-\mathrm{ME}$ & $\beta$-Mercatoethanol \\
\hline BSA & bovines Serumalbumin \\
\hline $\begin{array}{l}\text { BTB/POZ } \\
\text { ca. }\end{array}$ & $\begin{array}{l}\text { Bric à Brac/Tramtrack/Broad complex/POX Virus Zink-Finger } \\
\text { circa }\end{array}$ \\
\hline cDNA & complementary DNA \\
\hline CNT3 & $\begin{array}{l}\text { konzentrativer Nukleosid-Transporter } 3 \text { (concentrative nucleoside } \\
\text { transporter } 3 \text { ) }\end{array}$ \\
\hline CT & cycle of threshold \\
\hline DAPI & 4',6-Diamidino-2-Phenylindol \\
\hline$\Delta$ & Delta \\
\hline DMEM & Dulbecco's Modified Eagle Medium \\
\hline DMSO & Dimethylsulfoxid \\
\hline DNA & Desoxyribonukleinsäure (deoxyribonucleic acid) \\
\hline dNTPs & Desoxyribonukleosidtriphosphate \\
\hline EDTA & Ethylendiamintetraacetat \\
\hline ENT & $\begin{array}{l}\text { equilibrativer Nukleosid-Transporter (equilibrative nucleoside } \\
\text { transporter) }\end{array}$ \\
\hline FAM & Carboxy-Fluorescein \\
\hline FCS & fetal calf serum \\
\hline FRET & Fluoreszenz-Resonanz-Energie-Transfer \\
\hline 5-FdUMP & 5-Fluorodeoxyurinmonophospat \\
\hline 5-FdUTP & 5-Fluorodeoxyuridintriphosphat \\
\hline $5-F U$ & 5-Fluorouracil \\
\hline 5-FUDR & 5-Fluordeoxyuridin \\
\hline 5-FUTP & Fluorouridintriphosphat \\
\hline
\end{tabular}




\begin{tabular}{|c|c|}
\hline GAPDH & Glycerinaldehyd-3-Phosphat-Dehydrogenase \\
\hline$H G$ & high glucose \\
\hline HNF & hepatocyte nuclear factor \\
\hline $\mathrm{H}_{2} \mathrm{O}$ & Wasser \\
\hline MATE & multidrug and toxin extrusion \\
\hline MDR1 & Multidrug-Resistance-Protein 1 \\
\hline mRNA & messenger RNA (Boten-RNA) \\
\hline miRNA & mikroRNA \\
\hline MRP2 & Multidrug-Resistance-associated-Protein 2 \\
\hline $\mathrm{n}$ & Anzahl (number) \\
\hline n.s. & nicht signifikant \\
\hline n.u. & nicht untersucht \\
\hline NZK & Nierenzellkarzinom \\
\hline OAT & Organische-Anionen-Transporter \\
\hline OCT & Organische-Kationen-Transporter \\
\hline OCTN & Organische-Kationen/Carnitin-Transporter \\
\hline Oligo-dT & Oligo-Desoxythymidin \\
\hline $\mathrm{PAH}$ & para-Aminohippursäure \\
\hline PBS & Phosphat-gepufferte Salzlösung (phosphate buffered saline) \\
\hline PCR & Polymerase-Kettenreaktion (polymerase chain reaction) \\
\hline RNA & Ribonukleinsäure (ribonucleic acid) \\
\hline rRNA & ribosomale RNA \\
\hline RNase & Ribonuklease \\
\hline SEM & standard error of the mean \\
\hline SiRNA & small interfering RNA \\
\hline SLC & solute carrier \\
\hline SN38 & 7-Ethyl-10-Hydroxy-Camptothecin, aktiver Metabolit von Irinotecan \\
\hline Tab. & Tabelle \\
\hline TAMRA & 6-Carboxy-Tetramethyl-Rhodamin \\
\hline TBE & Tris-Borat-EDTA-Puffer \\
\hline TRF & telomeric repeat binding factor \\
\hline Tris & Trishydroxymethylaminomethan \\
\hline tRNA & Transfer-RNA \\
\hline Upm & Umdrehungen pro Minute \\
\hline UV & ultraviolett \\
\hline
\end{tabular}




\subsection{Einheiten}

$\begin{array}{llll}\text { bp } & \text { Basenpaar } & \text { M } & \text { Molarität } \\ { }^{\circ} \mathrm{C} & \text { Grad Celsius } & \mu & \text { Mikro } \\ \mathrm{g} & \text { Fallbeschleunigung } & \mathrm{n} & \text { Nano } \\ \mathrm{g} & \text { Gramm } & \mathrm{p} & \text { Pico } \\ \mathrm{kb} & \text { Kilobasenpaar } & \text { sek } & \text { Sekunden } \\ \mathrm{kDa} & \text { Kilodalton } & \mathrm{U} & \text { unit (Einheit der Enzymaktivität) } \\ \mathrm{I} & \text { Liter } & \mathrm{V} & \text { Volt } \\ \mathrm{m} & \text { Milli } & \text { w/v } & \text { Masse pro Volumen (weight per volume) }\end{array}$

min Minute

\subsection{Abbildungsverzeichnis}

Abbildung 1.1: Das Nephron.

Abbildung 1.2: Schematische Darstellung des BCL6-Proteins.

Abbildung 1.3: Die Chemoresistenz der Nierenkarzinomzellen könnte durch gesteigerte Expression der SLC22-Transporter überwunden werden.

Abbildung 3.1: Lichtmikroskopische Aufnahmen der Zelllinien (A) 786-O, (B) ACHN, (C)

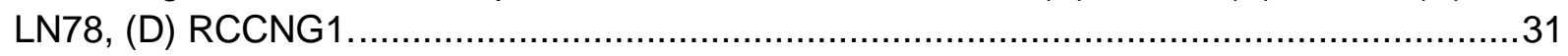

Abbildung 3.2: Nachweis des BCL6-Gens in der Zelllinie 786-O. .......................................32

Abbildung 3.3: Nachweis des BCL6-Gens in der Zelllinie ACHN. ....................................33

Abbildung 3.4: Nachweis des BCL6-Gens in der Zelllinie LN78.....................................33

Abbildung 3.5: Nachweis des BCL6-Gens in der Zelllinie RCCNG1. .................................34

Abbildung 3.6: GAPDH-Expression in den Zelllinien 786-O, ACHN, LN78 und RCCNG1

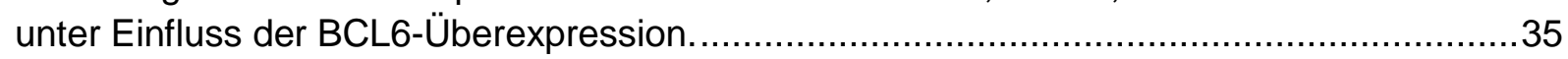

Abbildung 3.7: Beeinflussung der Expression von OATs und OCT1 durch BCL6-

Überexpression in der Nierenkarzinomzelllinie 786-O.

Abbildung 3.8: Beeinflussung der Expression von OAT10 und OCT1 durch BCL6-

Überexpression in der Nierenkarzinomzelllinie ACHN.

Abbildung 3.9: Beeinflussung der Expression von OATs und OCT1 durch BCL6-

Überexpression in der Nierenkarzinomzelllinie LN78.

Abbildung 3.10: Beeinflussung der Expression von OATs, OATs, OCTs MRP2 und MDR1 durch BCL6-Überexpression in der Nierenkarzinomzelllinie RCCNG1. .

Abbildung 3.11: BCL6-Expression in RCCNG1-Zellen. Immunhistochemische Färbung. .....41

Abbildung 3.12: Immunfluoreszenz-Nachweis von BCL6 in 786-O, ACHN, LN78 und RCCNG1.

Abbildung 3.13: Caspaseaktivität nach Inkubation mit 5-FU. 
Abbildung 3.14: Caspaseaktivität nach Inkubation mit Irinotecan. .44

Abbildung 3.15: Caspaseaktivität nach Inkubation mit Oxaliplatin. .45

\subsection{Tabellenverzeichnis}

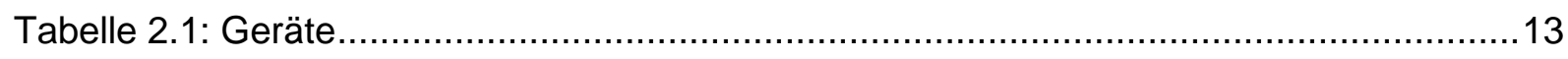

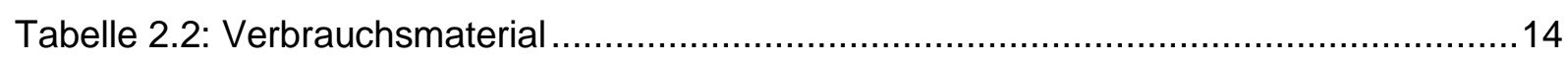

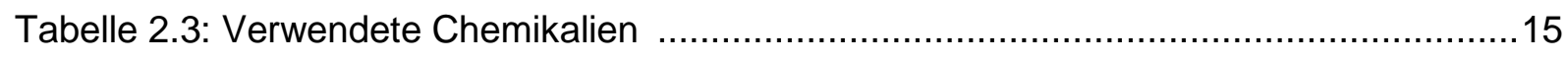

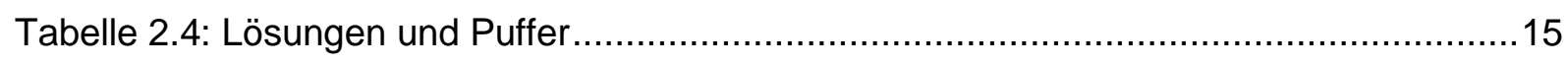

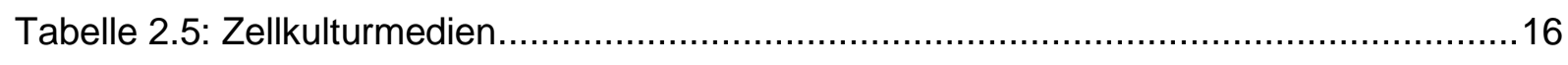

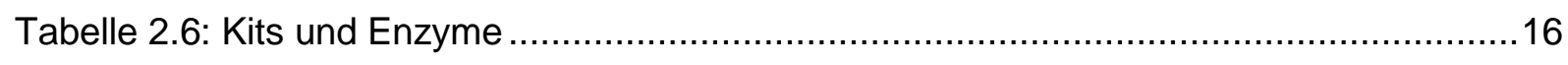

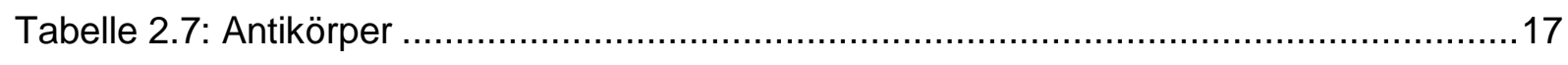

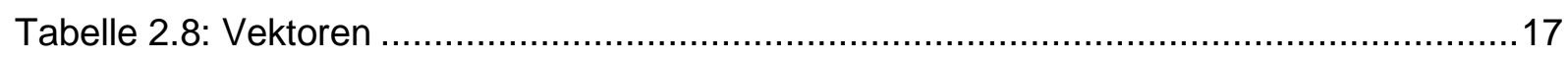

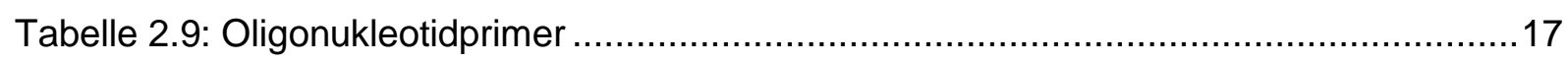

Tabelle 2.10: Übersicht über die verwendeten TaqMan® Assays mit ihren Spleißvarianten 18

Tabelle 2.11: Software........................................................................................ 19

Tabelle 2.12: Online-Datenbanken ....................................................................... 19

Tabelle 2.13: Temperaturvorgaben Schritt 1: Denaturierung der RNA ...............................24

Tabelle 2.14: Zusammensetzung des Mastermixes für die cDNA-Synthese .........................24

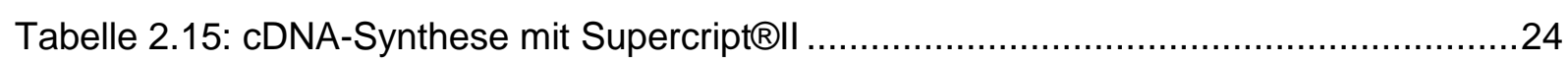

Tabelle 2.16: Mastermix-Zusammensetzung für die Standard-PCR ..................................25

Tabelle 2.17: Thermocycler-Programm für die Standard-PCR .......................................25

Tabelle 2.18: Reaktionsansatz der TaqMan® real-time PCR .........................................27

Tabelle 2.19: Bedingungen der TaqMan $\AA$ real-time PCR .............................................27

Tabelle 3.1: Tabellarische Zusammenfassung der real-time PCR-Analyse.........................40

Tabelle 4.1: Mögliche Zytostatika-Transporter der SLC- und ABC-Familie .........................48 


\section{Literaturverzeichnis}

Alberts B, Johnson A, Lewis J, Raff M, Roberts K, Walter P:

Molekularbiologie der Zelle.

5. Auflage;

Übersetzung hrsg. v. Schäfer U.

Wiley-VCH Verlag, Weinheim 2011

Alebouyeh M, Takeda M, Onozato ML, Tojo A, Noshiro R, Hasannejad H, Inatomi J, Narikawa S, Huang XL, Khamdang S, Anzai N, Endou H (2003):

Expression of human organic anion transporters in the choroid plexus and their interactions with neurotransmitter metabolites.

J Pharmacol Sci $\underline{93}, 430-436$

Altieri P, Spallarossa P, Barisione C, Garibaldi S, Garuti A, Fabbi P, Ghigliotti G, Brunelli C (2012):

Inhibition of doxorubicin-induced senescence by PPAR $\delta$ activation agonists in cardiac muscle cells: cooperation between PPAR $\delta$ and Bcl6.

PLoS One $\underline{7}$, e46126

Armanios M, Blackburn EH (2012):

The telomere syndromes.

Nat Rev 13, 693-704

Bahn A, Hagos Y, Reuter S, Balen D, Brzica H, Krick W, Burckhardt BC, Sabolic I, Burckhardt G (2008):

Identification of a new urate and high affinity nicotinate transporter, hOAT10 (SLC22A13).

J Biol Chem 283, 16332-16341

Basso K, Dalla-Favera $R$ (2012):

Roles of BCL6 in normal and transformed germinal center B cells.

Immunol Rev 247, 172-183

Bereshchenko OR, Gu W, Dalla-Favera R (2002):

Acetylation inactivates the transcriptional repressor BCL6.

Nat Genet $\underline{32}$, 606-613

Beretta GL, Benedetti V, Cossa G, Assaraf YG, Bram E, Gatti L, Corna E, Carenini N, Colangelo D, Howell SB, Zunino F, Perego P (2010):

Increased levels and defective glycosylation of MRPs in ovarian carcinoma cells resistant to oxaliplatin.

Biochem Pharmacol $\underline{79}, 1108-1117$

Bergeron MJ, Simonin A, Bürzle M, Hediger MA (2008):

Inherited epithelial transporter disorders--an overview.

$\mathrm{J}$ Inherit Metab Dis $\underline{31}, 178-187$ 
Bleasby K, Chauhan S, Brown CD (2000):

Characterization of MPP+ secretion across human intestinal Caco-2 cell monolayers: role of $\mathrm{P}$-glycoprotein and a novel $\mathrm{Na}(+)$-dependent organic cation transport mechanism.

Br J Pharmacol $\underline{129}, 619-625$

\section{Bradford MM (1976):}

A rapid and sensitive method for the quantitation of microgram quantities of protein utilizing the principle of protein-dye binding.

Anal Biochem $\underline{72}, 248-254$

Burckhardt BC, Burckhardt G (2003):

Transport of organic anions across the basolateral membrane of proximal tubule cells.

Rev Physiol Biochem Pharmacol 146, 95-158

Burckhardt G (2012):

Drug transport by Organic Anion Transporters (OATs).

Pharmacol Ther $\underline{136}, 106-130$

Burckhardt G, Wolff NA (2000):

Structure of renal organic anion and cation transporters.

Am J Physiol Renal Physiol 278, F853-866

Burckhardt G, Burckhardt BC (2011):

In Vitro and In Vivo Evidence oft he Importance of Organic Anion Transporters (OATs) in Drug Therapy.

Handb Exp Pharmacol 201, 29-104

Burger H, Zoumaro-Djayoon A, Boersma AW, Helleman J, Berns EM, Mathijssen RH, Loos WJ, Wiemer EA (2010):

Differential transport of platinum compounds by the human organic cation transporter hOCT2 (hSLC22A2).

Br J Pharmacol 159, 898-908

Campbell NA, Reece JB:

Biologie.

6., überarbeitete Auflage;

Pearson Education Deutschland, München 2006

964

Cha SH, Sekine T, Kusuhara H, Yu E, Kim JY, Kim DK, Sugiyama Y, Kanai Y, Endou H (2000):

Molecular cloning and characterization of multispecific organic anion transporter 4 expressed in the placenta.

J Biol Chem 275, 4507-4512

Cha SH, Sekine T, Fukushima Jl, Kanai Y, Kobayashi Y, Goya T, Endou H (2001): Identification and characterization of human organic anion transporter 3 expressing predominantly in the kidney.

Mol Pharmacol $\underline{59}$, 1277-1286 
Chang CC, Ye BH, Chaganti RS and Dalla-Favera $R$ (1996):

$\mathrm{BCL}-6$, a POZ/zinc-finger protein, is a sequence-specific transcriptional repressor.

Proc Natl Acad Sci U S A $\underline{93}$, 6947-6952

Chen Y, Zhang S, Sorani M, Giacomini KM (2007):

Transport of paraquat by human organic cation transporters and multidrug and toxic compound extrusion family.

J Pharmacol Exp Ther $\underline{322}$, 695-700

Chen Y, Li S, Brown C, Cheatham S, Castro RA, Leabman MK, Urban TJ, Chen L, Yee SW, Choi JH, Huang Y, Brett CM, Burchard EG, Giacomini KM (2009):

Effect of genetic variation in the organic cation transporter 2 on the renal elimination of metformin.

Pharmacogenet Genomics $\underline{19}$, 497-504

Chen ZS, Tiwari AK (2011):

Multidrug resistance proteins (MRPs/ABCCs) in cancer chemotherapy and genetic diseases.

FEBS J 2 278, 3226-3245

Chomczynski P, Sacchi N (1987):

Single-step method of RNA isolation by acid guanidinium thiocyanate-phenol-chloroform extraction.

Anal Biochem 162, 156-159

Ciarimboli G, Ludwig T, Lang D, Pavenstädt H, Koepsell H, Piechota HJ, Haier J, Jaehde U, Zisowsky J, Schlatter E (2005):

Cisplatin nephrotoxicity is critically mediated via the human organic cation transporter 2 .

Am J Pathol $\underline{167}, 1477-1484$

Ciarimboli G, Holle SK, Vollenbröcker B, Hagos Y, Reuter S, Burckhardt G, Bierer S, Herrmann E, Pavenstädt $H$, Rossi R, Kleta R, Schlatter E (2011):

New clues for nephrotoxicity induced by ifosfamide: preferential renal uptake via the human organic cation transporter 2.

Mol Pharm $\underline{8}, 270-279$

Clevers H(2006):

$\mathrm{Wnt} /$ beta-catenin signaling in development and disease.

Cell $\underline{127}, 469-480$

Costoya JA (2007):

Functional analysis of the role of POK transcriptional repressors.

Brief Funct Genomic Proteomic $\underline{6}$, 8-18

Cui Y, König J, Buchholz JK, Spring H, Leier I, Keppler D (1999):

Drug resistance and ATP-dependent conjugate transport mediated by the apical multidrug resistance protein, MRP2, permanently expressed in human and canine cells.

Mol Pharmacol $\underline{55}$, 929-937 
De Gramont A, Figer A, Seymour M, Homerin M, Hmissi A, Cassidy J, Boni C, CortesFunes $H$, Cervantes A, Freyer G, Papamichael D, Le Bail N, Louvet C, Hendler D, de Braud F, Wilson C, Morvan F, Bonetti A (2000):

Leucovorin and fluorouracil with or without oxaliplatin as first-line treatment in advanced colorectal cancer.

J Clin Oncol 18, 2938-2947

De Lange T (2005):

Shelterin: the protein complex that shapes and safeguards human telomeres.

Genes Dev $\underline{19}$, 2100-2110

Dean M, Allikmets $R$ (1995):

Evolution of ATP-binding cassette transporter genes.

Curr Opin Genet Dev $\underline{5}, 779-785$

\section{Dempke W:}

Lehrbuch Hämato-Onkologie.

1. Auflage;

Verlag Hans Huber, Hogrefe 2006

$269-276$

Dent AL, Vasanwala FH, Toney LM (2002):

Regulation of gene expression by proto-oncogene BCL-6.

Crit Rev Oncol Hematol 41, 1-9

Dutcher J (2002):

Current status of interleukin-2 therapy for metastatic renal cell carcinoma and metastatic melanoma.

Oncology $\underline{16}$, 4-10

Ekaratanawong S, Anzai N, Jutabha $P$, Miyazaki H, Noshiro R, Takeda M, Kanai $Y$, Sophasan S, Endou H (2004):

Human organic anion transporter 4 is a renal apical organic anion/dicarboxylate exchanger in the proximal tubules.

J Pharmacol Sci $\underline{94}, 297-304$

Emami Riedmaier A, Nies AT, Schaeffeler E, Schwab M (2012):

Organic anion transporters and their implications in pharmacotherapy.

Pharmacol Rev $\underline{64}, 421-449$

Foley FB, Mulvaney WP, Richardson EJ, Victor I (1952):

Radical nephrectomy for neoplasms.

J Urol $\underline{68}, 39-49$

Fulton DL, Sundararajan S, Badis G, Hughes TR, Wasserman WW, Roach JC, Sladek R (2009):

TFCat: the curated catalog of mouse and human transcription factors.

Genome Biol $\underline{10}$, R29 
Gebrosky NP, Koukol S, Nseyo UO, Carpenter C, Lamm DL (1997):

Treatment of renal cell carcinoma with 5-fluorouracil and alfa-interferon.

Urology $\underline{50}$, 863-867

George CM, Vogelzang NJ, Rini BI, Geoffroy FJ, Kollipara P, Stadler WM (2002):

A phase II trial of weekly intravenous gemcitabine and cisplatin with continuous infusion fluorouracil in patients with metastatic renal cell carcinoma.

Ann Oncol $\underline{13}, 116-120$

Gerk PM, Vore M (2002):

Regulation of expression of the multidrug resistance-associated protein 2 (MRP2) and its role in drug disposition.

J Pharmacol Exp Ther $\underline{302}, 407-415$

Gorboulev V, Ulzheimer JC, Akhoundova A, Ulzheimer-Teuber I, Karbach U, Quester S, Baumann C, Lang F, Busch AE, Koepsell H (1997):

Cloning and characterization of two human polyspecific organic cation transporters.

DNA Cell Biol 16, 871-881

Goyal R, Gersbach E, Yang XJ, Rohan SM (2013):

Differential diagnosis of renal tumors with clear cytoplasm: clinical relevance of renal tumor subclassification in the era of targeted therapies and personalized medicine.

Arch Pathol Lab Med 137, 467-480

Grottker J, Rosenberger A, Burckhardt G, Hagos Y (2011):

Interaction of human multidrug and toxin extrusion 1 (MATE1) transporter with antineoplastic agents.

Drug Metabol Drug Interact 26, 181-189

Gupta S, Burckhardt G, Hagos Y (2011a):

SLC22 transporter family proteins as targets for cytostatic uptake into tumor cells.

Biol Chem 392, 117-124

Gupta S, Wulf G, Henjakovic M, Koepsell H, Burckhardt G, Hagos Y (2011b).

Human organic cation transporter 1 is expressed in lymphoma cells and increases susceptibility to irinotecan and paclitaxel.

J Pharmacol Exp Ther 341, 16-23

Hagos Y, Stein D, Ugele B, Burckhardt G, Bahn A (2007):

Human renal organic anion transporter 4 operates as an asymmetric urate transporter.

J Am Soc Nephrol 18, 430-439

Hagos Y, Wegner W, Kuehne A, Floerl S, Marada VV, Burckhardt G, Henjakovic M (2014):

HNF4 $\alpha$ induced chemosensitivity to oxaliplatin and 5-FU mediated by OCT1 and CNT3 in renal cell carcinoma.

J Pharm Sci 103, 3326-3334 
Hautmann RE, Huland H:

Urologie.

2., vollständig überarbeitete Auflage;

Springer-Verlag, Berlin 2001

Hayer-Zillgen M, Brüss M, Bönisch H (2002):

Expression and pharmacological profile of the human organic cation transporters hOCT1, hOCT2 and hOCT3.

Br J Pharmacol 136, 829-836

Heidelberger C, Chaudhuri NK, Danneberg P, Mooren D, Griesbach L, Duschinsky R, Schnitzer RJ, Pleven E, Scheiner J (1957):

Fluorinated pyrimidines, a new class of tumor-inhibitory compounds.

Nature $\underline{197}, 663-666$

Heise M, Lautem A, Knapstein J, Schattenberg JM, Hoppe-Lotichius M, Foltys D, Weiler N, Zimmermann A, Schad A, Grundemann D, Otto G, Galle PR, Schuchmann M, Zimmermann T (2012):

Downregulation of organic cation transporters OCT1 (SLC22A1) and OCT3 (SLC22A3) in human hepatocellular carcinoma and their prognostic significance.

BMC Cancer 12, 109

Hilgendorf C, Ahlin G, Seithel A, Artursson P, Ungell AL, Karlsson J (2007):

Expression of thirty-six drug transporter genes in human intestine, liver, kidney, and organotypic cell lines.

Drug Metab Dispos 35, 1333-1340

Hoffmann U, Kroemer HK (2004):

The ABC Transporters MDR1 and MRP2: Multiple Functions in Disposition of Xenobiotics and Drug Resistance.

Drug Metab Rev $\underline{36}, 669-701$

Hosoyamada M, Sekine T, Kanai Y, Endou H (1999):

Molecular cloning and functional expression of a multispecific organic anion transporter from human kidney.

Am J Physiol 276, F122-128

Hsu RJ, Ho JY, Cha TL, Yu DS, Wu CL, Huang WP, Chu P, Chen YH, Chen JT, Yu CP (2012):

WNT10A plays an oncogenic role in renal cell carcinoma by activating WNT/beta-catenin pathway.

PLoS One $\underline{7}$, e47649

Huang $Y$ (2007):

Pharmacogentics/genomics of membrane transporters in cancer chemotherapy.

Cancer and Metastasis Reviews 26, 183-201 
Huls M, Russel FG, Masereeuw R (2009):

The role of ATP binding cassette transporters in tissue defense and organ regeneration.

J Pharmacol Exp Ther $\underline{328}$, 3-9

Ikehata M, Ueda K, Iwakawa S (2012):

Different involvement of DNA methylation and histone deacetylation in the expression of solute-carrier transporters in 4 colon cancer cell lines.

Biol Pharm Bull 35, 301-307

Iorio MV, Ferracin M, Liu CG, Veronese A, Spizzo R, Sabbioni S, Magri E, Pedriali M, Fabbri M, Campiglio M, Ménard S, Palazzo JP, Rosenberg A, Musiani P, Volinia S, Nenci I, Calin GA, Querzoli P, Negrini M, Croce CM (2005):

MicroRNA gene expression deregulation in human breast cancer.

Cancer Res $\underline{65}$, 7065-7070

Jacobsson JA, Haitina T, Lindblom J, Fredriksson R (2007):

Identification of six putative human transporters with structural similarity to the drug transporter SLC22 family.

Genomics $\underline{90}, 595-609$

Jin L, Kikuchi R, Saji T, Kusuhara H, Sugiyama Y (2012):

Regulation of tissue-specific expression of renal organic anion transporters by hepatocyte nuclear factor $1 \alpha / \beta$ and DNA methylation.

J Pharmacol Exp Ther $\underline{340}, 648-655$

Jong NN, Nakanishi T, Liu JJ, Tamai I, McKeage MJ (2011):

Oxaliplatin transport mediated by organic cation/carnitine transporters OCTN1 and OCTN2 in overexpressing human embryonic kidney 293 cells and rat dorsal root ganglion neurons.

J Pharmacol Exp Ther $\underline{338}, 537-547$

Jonker JW, Schinkel AH (2004):

Pharmacological and physiological functions of the polyspecific organic cation transporters: OCT1, 2, and 3.

J Pharmacol Exp Ther $\underline{308}, 2-9$

Kikuchi R, Kusuhara H, Hattori N, Shiota K, Kim I, Gonzalez FJ, Sugiyama Y (2006):

Regulation of the expression of human organic anion transporter 3 by hepatocyte nuclear factor $1 \alpha / \beta$ and DNA methylation.

Mol Pharmacol $\underline{70}$, 887-896

Kim DH, Park JY, Sohn SK, Lee NY, Baek JH, Jeon SB, Kim JG, Suh JS, Do YR, Lee KB (2006):

Multidrug resistance-1 gene polymorphisms associated with treatment outcomes in de novo acute myeloid leukemia.

Int J Cancer 118, 2195-2201 
Kitada N, Takara K, Minegaki T, Itoh C, Tsujimoto M, Sakaeda T, Yokoyama T (2008):

Factors affecting sensitivity to antitumor platinum derivatives of human colorectal tumor cell lines.

Cancer Chemother Pharmacol $\underline{62}$, 577-584

Klinke R, Pape HC, Silbernagl S:

Physiologie.

6. Auflage;

Georg Thieme Verlag, Stuttgart 2010

Kobayashi Y, Ohshiro N, Tsuchiya A, Kohyama N, Ohbayashi M, Yamamoto T (2004):

Renal transport of organic compounds mediated by mouse organic anion transporter 3 (mOat3): further substrate specificity of mOat3.

Drug Metab Dispos $\underline{32}, 479-483$

Kobayashi Y, Ohshiro N, Sakai R, Ohbayashi M, Kohyama N, Yamamoto T (2005): Transport mechanism and substrate specificity of human organic anion transporter 2 (hOat2 [SLC22A7]).

J Pharm Pharmacol $\underline{57}, 573-578$

Koepsell H, Endou H (2004):

The SLC22 drug transporter family.

Pflugers Arch $\underline{447}, 666-676$

Koepsell H, Schmitt, BM, Gorboulev V (2003):

Organic cation transporters.

Rev Physiol Biochem Pharmacol 150, 36-90

Koepsell H, Lips K, Volk C (2007):

Polyspecific organic cation transporters: structure, function, physiological roles, and biopharmaceutical implications.

Pharm Res 노, 1227-1251

Kojima S, Hatano M, Okada S, Fukuda T, Toyama Y, Yuasa S, Ito H, Tokuhisa T (2001): Testicular germ cell apoptosis in Bcl6-deficient mice.

Development $\underline{128}$, 57-65

Koul H, Huh JS, Rove KO, Crompton L, Koul S, Meacham RB, Kim FJ (2011):

Molecular aspects of renal cell carcinoma: a review.

Am J Cancer Res 1, 240-254

Kusuhara H, Sugiyama $Y$ (2009):

In vitro-in vivo extrapolation of transporter-mediated clearance in the liver and kidney. Drug Metab Pharmacokinet 24, 37-52 
Lee MA, Byun JH, Shim BY, Woo IS, Kang JH, Hong YS, Lee KS, Choi MG, Chang SK, Oh ST, Choi SI, Lee DS (2005):

Irinotecan, continuous 5-fluorouracil, and low dose of leucovorin (modified FOLFIRI) as first line of therapy in recurrent or metastatic colorectal cancer.

Korean J Intern Med 20, 205-209

Lemercier C, Brocard MP, Puvion-Dutilleul F, Kao HY, Albagli O, Khochbin S (2002):

Class II histone deacetylases are directly recruited by BCL6 transcriptional repressor.

J Biol Chem 277, 22045-22052

Liu L, White MJ, MacRae TH (1999):

Transcription factors and their genes in higher plants functional domains, evolution and regulation.

Eur J Biochem 262, 247-257

Ljungberg B, Campbell SC, Choi HY, Jacqmin D, Lee JE, Weikert S, Kiemeney LA (2011):

The epidemiology of renal cell carcinoma.

Eur Urol $\underline{60}, 615-621$

\section{Löffler G, Petrides PE:}

Biochemie \& Pathobiochemie.

9. Auflage;

Springer-Verlag, Berlin 2014

Longo R, D'Andrea MR, Sarmiento R, Salerno F, Gasparini G (2007):

Integrated therapy of kidney cancer.

Ann Oncol 18, vi141-148

Lovejoy KS, Todd RC, Zhang S, McCormick MS, D'Aquino JA, Reardon JT, Sancar A, Giacomini KM, Lippard SJ (2008):

cis-Diammine(pyridine)chloroplatinum(II), a monofunctional platinum(II) antitumor agent: Uptake, structure, function, and prospects.

Proc Natl Acad Sci USA 105, 8902-8907

MacDonald BT, Tamai K, He X (2009):

Wnt/beta-catenin signaling: components, mechanisms, and diseases.

Dev Cell 17, 9-26

\section{Marada VVVR:}

Interaction of hepatic uptake transporters with antineoplastic compounds and regulation of the expression of organic cation transporter 3 in renal carcinoma cells.

Naturwiss. Diss. Göttingen 2014

Martel CL, Lara PN (2003):

Renal cell carcinoma: current status and future directions.

Crit Rev Oncol Hematol 45, 177-190 
Masereeuw R, Russel FGM (2012):

Regulatory Pathways for ATP-binding Cassette Transport Proteins in Kidney Proximal Tubules.

The AAPS Journal $\underline{14}$, 883-894

Masuda S, Terada T, Yonezawa A, Tanihara Y, Kishimoto K, Katsura T, Ogawa O, Inui $K$ (2006):

Identification and functional characterization of a new human kidney-specific $\mathrm{H}+$ /organic cation antiporter, kidney-specific multidrug and toxin extrusion 2.

J Am Soc Nephrol 17, 2127-2135

Miles RR, Crockett DK, Lim MS, Elenitoba-Johnson KS (2005):

Analysis of BCL6-interacting proteins by tandem mass spectrometry.

Mol Cell Proteomics 4, 1898-1909

Minematsu T, Giacomini KM (2011):

Interactions of tyrosine kinase inhibitors with organic cation transporters and multidrug and toxic compound extrusion proteins.

Mol Cancer Ther 10, 531-539

Motohashi H, Sakurai Y, Saito H, Masuda S, Urakami Y, Goto M, Fukatsu A, Ogawa O, Inui K (2002):

Gene expression levels and immunolocalization of organic ion transporters in the human kidney.

J Am Soc Nephrol 13, 866-874

Motzer RJ, Bander NH, Nanus DM (1996):

Renal-Cell Carcinoma.

N Engl J Med $\underline{335}, 865-875$

\section{Mülhardt C:}

Der Experimentator: Molekularbiologie/Genomics.

6. Auflage;

Spektrum Akademischer Verlag, Heidelberg 2009

Nishimura M, Naito S (2005):

Tissue-specific mRNA expression profiles of human ATPbinding cassette and solute carrier transporter families.

Drug Metab Pharmacokinet 20, 452-477

Nomura M, Matsunami T, Kobayashi K, Uchibayashi T, Koshida K, Tanaka M, Namiki M, Mizuhara Y, Akiba T, Yokogawa K, Moritani S, Miyamoto K (2005):

Involvement of $A B C$ transporters in chemosensitivity of human renal cell carcinoma, and regulation of MRP2 expression by conjugated bilirubin.

Anticancer Res 25, 2729-2735 
Ogasawara K, Terada T, Asaka J, Katsura T, Inui K (2006):

Human organic anion transporter 3 gene is regulated constitutively and inducibly via a cAMPresponse element.

J Pharmacol Exp Ther $\underline{319}$, 317-322

Otsuka M, Matsumoto T, Morimoto R, Arioka S, Omote H, Moriyama Y (2005):

A human transporter protein that mediates the final excretion step for toxic organic cations.

Proc Natl Acad Sci U S A 102, 17923-17928

Pal D, Sharma U, Singh SK, Kakkar N, Prasad R (2015):

Over-Expression of Telomere Binding Factors (TRF1 \& TRF2) in Renal Cell Carcinoma and Their Inhibition by Using SiRNA Induce Apoptosis, Reduce Cell Proliferation and Migration Invitro.

PLoS One $\underline{10}$, e0115651

\section{Pfaffl MW (2004):}

Real-time RT-PCR: Neue Ansätze zur exakten mRNA Quantifizierung.

Biospektrum 1, 92-95

Pratt S, Shepard RL, Kandasamy RA, Johnston PA, Perry W 3rd, Dantzig AH (2005):

The multidrug resistance protein 5 (ABCC5) confers resistance to 5-fluorouracil and transports its monophosphorylated metabolites.

Mol Cancer Ther $\underline{4}, 855-863$

Pullen TJ, da Silva Xavier G, Kelsey G, Rutter GA (2011):

miR-29a and miR-29b contribute to pancreatic beta-cell-specific silencing of monocarboxylate transporter 1 (Mct1).

Mol Cell Biol 31, 3182-3194

Ramesh M, Ahlawat $P$, Srinivas NR (2010):

Irinotecan and its active metabolite, SN-38: review of bioanalytical methods and recent update from clinical pharmacology perspectives.

Biomed Chromatogr 24, 104-123

Raymond E, Faivre S, Chaney S, Woynarowski J, Cvitkovic E (2002):

Cellular and molecular pharmacology of oxaliplatin.

Mol Cancer Ther 1 , 227-235

Rivory LP, Bowles MR, Robert J, Pond SM (1996):

Conversion of irinotecan (CPT-11) to its active metabolite, 7-ethyl-10-hydroxycamptothecin (SN-38), by human liver carboxylesterase.

Biochem Pharmacol 52, 1103-1111

Rizwan AN, Burckhardt G (2007):

Organic anion transporters of the SLC22 family: biopharmaceutical, physiological, and pathological roles.

Pharm Res $\underline{24}, 450-470$ 
Rothenberg ML (1997):

Topoisomerase I inhibitors: review and update.

Ann Oncol $\underline{8}$, 837-855

Rothenberg ML (2000):

Efficacy of oxaliplatin in the treatment of colorectal cancer.

Oncology $\underline{14}, 9-14$

Saito Y, Liang G, Egger G, Friedman JM, Chuang JC, Coetzee GA, Jones PA (2006):

Specific activation of microRNA-127 with downregulation of the proto-oncogene BCL6 by chromatin-modifying drugs in human cancer cells.

Cancer Cell $\underline{9}, 435-443$

Saji T, Kikuchi R, Kusuhara H, Kim I, Gonzalez FJ, Sugiyama Y (2008):

Transcriptional regulation of human and mouse organic anion transporter 1 by hepatocyte nuclear factor 1 alpha/beta.

J Pharmacol Exp Ther 324, 784-790

Sakurai Y, Motohashi H, Ueo H, Masuda S, Saito H, Okuda M, Mori N, Matsuura M, Doi T, Fukatsu A, Ogawa O, Inui K (2004):

Expression levels of renal organic anion transporters (OATs) and their correlation with anionic drug excretion in patients with renal diseases.

Pharm Res 21, 61-67

Sata R, Ohtani H, Tsujimoto M, Murakami H, Koyabu N, Nakamura T, Uchiumi T, Kuwano M, Nagata H, Tsukimori K, Nakano H, Sawada $Y$ (2005):

Functional analysis of organic cation transporter 3 expressed in human placenta.

J Pharmacol Exp Ther $\underline{315}$, 888-895

Schaub TP, Kartenbeck J, König J, Spring H, Dörsam J, Staehler G, Störkel S, Thon WF, Keppler D (1999):

Expression of the MRP2 gene-encoded conjugate export pump in human kidney proximal tubules and in renal cell carcinoma.

J Am Soc Nephrol 10, 1159-1169

Schilsky RL (1998):

Biochemical and clinical pharmacology of 5-fluorouracil.

Oncology $\underline{12}, 13-8$

\section{Schmidt R, Lang F, Heckmann M:}

Physiologie des Menschen mit Pathophysiologie.

31. Auflage;

Springer Medizin Verlag, Heidelberg 2010

Sekine T, Watanabe N, Hosoyamada M, Kanai Y, Endou H (1997):

Expression cloning and characterization of a novel multispecific organic anion transporter.

J Biol Chem 272, 18526 - 18529 
Sekine T, Miyazaki H, Endou H (2006):

Molecular physiology of renal organic anion transporters.

Am Am J Physiol Renal Physiol 290, F251-F261

\section{Sharom FJ (2008):}

ABC multidrug transporters: structure, function and role in chemoresistance.

Pharmacogenomics $\underline{9}, 105-127$

Shen DW, Pouliot LM, Hall MD, Gottesman MM (2012):

Cisplatin Resistance: A Cellular Self-Defense Mechanism Resulting from Multiple Epigenetic and Genetic Changes.

Pharmacol Rev $\underline{64}, 706-721$

\section{Shnitsar V:}

The expression of polyspecific transporters in renal tumors and their role in chemotherapeutical treatment.

Naturwiss. Diss. Göttingen 2008

Shnitsar V, Eckardt R, Gupta S, Grottker J, Müller GA, Koepsell H, Burckhardt G, Hagos $Y$ (2009):

Expression of human organic cation transporter 3 in kidney carcinoma cell lines increases chemosensitivity to melphalan, irinotecan, and vincristine.

Cancer Res $\underline{69}$, 1494-1501

\section{Silbernagl S, Despopoulos A:}

Taschenatlas Physiologie.

\section{Auflage;}

Georg Thieme Verlag, Stuttgart 2012

Soini Y, Järvinen K, Kaarteenaho-Wiik R, Kinnula V (2001):

The expression of P-glycoprotein and multidrug resistance proteins 1 and 2 (MRP1 and MRP2) in human malignant mesothelioma.

Ann Oncol 12, 1239-1245

Stadler WM, Halabi S, Rini B, Ernstoff MS, Davila E, Picus J, Barrier R, Small EJ; Cancer and Leukemia Group B (2006):

A phase II study of gemcitabine and capecitabine in metastatic renal cancer: a report of Cancer and Leukemia Group B protocol 90008.

Cancer 107, 1273-1279

Staudt LM, Dent AL, Shaffer AL, Yu X (1999):

Regulation of lymphocyte cell fate decisions and lymphomagenesis by BCL-6.

Int Rev Immunol 18, 381-403

Sültmann H, von Heydebreck A, Huber W, Kuner R, Buness A, Vogt M, Gunawan B, Vingron M, Füzesí L, Poustka A (2005):

Gene expression in kidney cancer is associated with cytogenetic abnormalities, metastasis formation, and patient survival.

Clin Cancer Res 11, 646-655 
Takeda M, Khamdang S, Narikawa S, Kimura H, Hosoyamada M, Cha SH, Sekine T, Endou $H$ (2002):

Characterization of methotrexate transport and its drug interactions with human organic anion transporters.

J Pharmacol Exp Ther $\underline{302}, 666-671$

Tanihara Y, Masuda S, Sato T, Katsura T, Ogawa O, Inui K (2007):

Substrate specificity of MATE1 and MATE2-K, human multidrug and toxin extrusions/ $\mathrm{H}_{+-}$ organic cation antiporters.

Biochem Pharmacol $\underline{74}$, 359-371

Todd RC, Lippard SJ (2009):

Inhibition of transcription by platinum antitumor compounds.

Metallomics 1 , 280-291

Toffoli G, Cecchin E, Corona G, Boiocchi M (2003):

Pharmacogenetics of irinotecan.

Curr Med Chem Anticancer Agents $\underline{3}, 225-237$

Valinezhad Orang A, Safaralizadeh R, Kazemzadeh-Bavili M (2014):

Mechanisms of miRNAMediated Gene Regulation from Common Downregulation to mRNASpecific Upregulation.

Int J Genomics 2014, 970607

Van Cutsem E, Nordlinger B, Cervantes A; ESMO Guidelines Working Group (2010):

Advanced colorectal cancer: ESMO Clinical Practice Guidelines for treatment.

Ann Oncol 21, v93-97

Waaler J, Machon O, von Kries JP, Wilson SR, Lundenes E, Wedlich D, Gradl D, Paulsen JE, Machonova O, Dembinski JL, Dinh H, Krauss S (2011):

Novel synthetic antagonists of canonical Wnt signaling inhibit colorectal cancer cell growth.

Cancer Res 1ㅡ, 197-205

Wagner SD, Ahearne M, Ferrigno PK (2011):

The role of BCL6 in lymphomas and routes to therapy.

British Journal of Haematology 152, 3-12

Walsh N, Larkin A, Kennedy S, Connolly L, Ballot J, Ooi W, Gullo G, Crown J, Clynes M, O'Driscoll L (2009):

Expression of multidrug resistance markers ABCB1 (MDR-1/P-gp) and ABCC1 (MRP-1) in renal cell carcinoma.

BMC Urol $\underline{9}, 6$

Watanabe S, Tsuda M, Terada T, Katsura T, Inui K (2010):

Reduced renal clearance of a zwitterionic substrate cephalexin in MATE1-deficient mice.

J Pharmacol Exp Ther 334, 651-656 
Waters JS, Moss C, Pyle L, James M, Hackett S, A'hern R, Gore M, Eisen T (2004):

Phase II clinical trial of capecitabine and gemcitabine chemotherapy in patients with metastatic renal carcinoma.

Br J Cancer 91, 1763-1768

Wegner W, Burckhardt BC, Burckhardt G, Henjakovic M (2012):

Male-dominant activation of rat renal organic anion transporter 1 (Oat1) and 3 (Oat3) expression by transcription factor BCL6.

PLoS One $\underline{7}$, e35556

Wegner W, Burckhardt G, Henjakovic M2 (2014):

Transcriptional regulation of human organic anion transporter 1 by B-cell CLL/lymphoma 6 .

Am J Physiol Renal Physiol 307, F1283-1291

Wright SH, Dantzler WH (2004):

Molecular and cellular physiology of renal organic cation and anion transport.

Physiol Rev 84, 987-1049

Wu MH, Yan B, Humerickhouse R, Dolan ME (2002):

Irinotecan activation by human carboxylesterases in colorectal adenocarcinoma cells.

Clin Cancer Res $\underline{8}$, 2696-2700

Wu W, Baker ME, Eraly SA, Bush KT, Nigam SK (2009):

Analysis of a large cluster of SLC22 transporter genes, including novel USTs, reveals species-specific amplification of subsets of family members.

Physiol Genomics $\underline{38}$, 116-124

Wu X, Huang W, Ganapathy ME, Wang H, Kekuda R, Conway SJ, Leibach FH, Ganapathy V (2000):

Structure, function, and regional distribution of the organic cation transporter OCT3 in the kidney.

Am J Physiol Renal Physiol 279, F449-458

Xu X, Wu J, Li S, Hu Z, Xu X, Zhu Y, Liang Z, Wang X, Lin Y, Mao Y, Chen H, Luo J, Liu $B$, Zheng $X$, Xie L (2014):

Downregulation of microRNA-182-5p contributes to renal cell carcinoma proliferation via activating the AKT/FOXO3a signaling pathway.

Mol Cancer $\underline{13}, 109$

Ye BH, Lista F, Lo Coco F, Knowles DM, Offit K, Chaganti RS, Dalla Favera R (1993):

Alterations of a zinc finger-encoding gene, BCL-6, in diffuse large-cell lymphoma

Sciene $\underline{262}, 747-750$

Yokoo S, Yonezawa A, Masuda S, Fukatsu A, Katsura T, Inui K (2007):

Differential contribution of organic cation transporters, OCT2 and MATE1, in platinum agentinduced nephrotoxicity.

Biochem Pharmacol $\underline{74}, 477-487$ 
Yonezawa A, Masuda S, Yokoo S, Katsura T, Inui K (2006):

Cisplatin and oxaliplatin, but not carboplatin and nedaplatin, are substrates for human organic cation transporters (SLC22A1-3 and multidrug and toxin extrusion family).

J Pharmacol Exp Ther $\underline{319}$, 879-886

Zhang L, Dresser MJ, Gray AT, Yost SC, Terashita S, Giacomini KM (1997):

Cloning and functional expression of a human liver organic cation transporter.

Mol. Pharmacol $\underline{51}, 913-921$

Zhang S, Lovejoy KS, Shima JE, Lagpacan LL, Shu Y, Lapuk A, Chen Y, Komori T, Gray JW, Chen X, Lippard SJ, Giacomini KM (2006):

Organic cation transporters are determinants of oxaliplatin cytotoxicity.

Cancer Res $\underline{66}, 8847-8857$

Zhang Y, Laz EV, Waxman DJ (2012):

Dynamic, sex-differential STAT5 and BCL6 binding to sex-biased, growth hormone-regulated genes in adult mouse liver.

Mol Cell Biol $\underline{32}, 880-896$

Zhou SF (2008):

Structure, function and regulation of P-glycoprotein and its clinical relevance in drug disposition.

Xenobiotica $\underline{38}, 802-832$ 


\section{Danksagung}

Ich bedanke mich zu allererst bei Frau Dr. Maja Henjakovic. Sie hat mich vom ersten Tag meiner Arbeit begleitet und stand mir mit ihrer stetigen Unterstützung und Geduld jederzeit mit Rat und Tat zur Seite. Ihre engagierte Betreuung hat entscheidend zum Gelingen meiner Dissertation beigetragen.

Herrn Prof. Dr. Gerhard Burckhardt, meinem Doktorvater, bin ich für das Überlassen des Dissertationsthemas zu großem Dank verpflichtet. Er ermöglichte mir die Promotion in der Abteilung vegetative Physiologie und Pathophysiologie. Ich möchte mich für seine Anregungen beim Schreiben dieser Dissertation bedanken und dass ich ihn stets um Rat fragen konnte.

Ganz besonders möchte ich mich auch bei allen Mitarbeitern der Abteilung vegetative Physiologie und Pathophysiologie, insbesondere bei Frau Gesche Dallmayer, für ihre Unterstützung bedanken.

Des Weiteren möchte ich mich bei allen bedanken, die mich während der Promotion wissenschaftlich unterstützt und immer wieder motiviert haben. Deswegen danke ich Christina Haas und Dr. Christian Engelke. 